\title{
Molybdenum-Containing Metalloenzymes and Synthetic Catalysts for Conversion of Small Molecules
}

\author{
Donghyeon Kim, Jaeheon Lee and Junhyeok Seo * D \\ Department of Chemistry, Gwangju Institute of Science and Technology, Gwangju 61005, Korea; \\ kdhdh934@gist.ac.kr (D.K.); jaeheonlee@gist.ac.kr (J.L.) \\ * Correspondence: seojh@gist.ac.kr
}

Citation: Kim, D.; Lee, J.; Seo, J. Molybdenum-Containing Metalloenzymes and Synthetic Catalysts for Conversion of Small Molecules. Catalysts 2021, 11, 217. https://doi.org/10.3390/ catal11020217

Academic Editor: Carla D. Nunes

Received: 2 January 2021

Accepted: 3 February 2021

Published: 6 February 2021

Publisher's Note: MDPI stays neutral with regard to jurisdictional claims in published maps and institutional affiliations.

Copyright: (C) 2021 by the authors. Licensee MDPI, Basel, Switzerland. This article is an open access article distributed under the terms and conditions of the Creative Commons Attribution (CC BY) license (https:/ / creativecommons.org/licenses/by/ $4.0 /)$.

\begin{abstract}
The energy deficiency and environmental problems have motivated researchers to develop energy conversion systems into a sustainable pathway, and the development of catalysts holds the center of the research endeavors. Natural catalysts such as metalloenzymes have maintained energy cycles on Earth, thus proving themselves the optimal catalysts. In the previous research results, the structural and functional analogs of enzymes and nano-sized electrocatalysts have shown promising activities in energy conversion reactions. Mo ion plays essential roles in natural and artificial catalysts, and the unique electrochemical properties render its versatile utilization as an electrocatalyst. In this review paper, we show the current understandings of the Mo-enzyme active sites and the recent advances in the synthesis of Mo-catalysts aiming for high-performing catalysts.
\end{abstract}

Keywords: molybdenum; metalloenzymes; FDH; CODH; nitrogenase; homogeneous; heterogeneous electrocatalysts; HER; OER

\section{Introduction}

Fixation of atmospheric nitrogen to ammonia has been promoted by the Haber-Bosch process, and the capacitated mass production of foods accelerated the increase of the world population [1,2]. The rapid growth of fossil fuel-based industry unavoidably increased atmospheric $\mathrm{CO}_{2}$, and resultantly aggravated the global warming and climate crisis. To suggest solutions for those anthropogenic issues and mitigate the current environmental problems, scientific progress to convert fossil fuel-based energy systems toward sustainable ways is keenly desired along with other social and economic efforts [3]. In the line of scientific cognition, we review catalysts for energy conversion reactions including small molecules such as $\mathrm{CO}_{2}, \mathrm{~N}_{2}, \mathrm{H}_{2}$, and $\mathrm{O}_{2}$ as reactants or products. Numerous catalysts have been developed in recent decades owing to the high interest in energy conversion reactions [4-8]. Mo ion is found to be an essential component in biological catalysis [9], as well as a very promising metal candidate among Earth-abundant metals for applications to electrocatalysts and photocatalysts $[4,10,11]$. Herein, we review versatile utilization of Mo ions in natural and synthetic catalysts.

Mo-containing homogeneous catalysts utilize both low- and high-valent Mo ions, whereas metalloenzymes and their model complexes have high-valent Mo centers. Except for FeMo-nitrogenase [12], Mo-enzyme active sites always use dithiolene ligation of the molybdopterin (MPT) moiety to stabilize a Mo(IV/VI) ion during the redox reaction and to assist electron transfer between metal and ligand [13]. Moreover, the chalcogenide ligand and nearby amino acid play essential roles to determine the selective reactivity of Mo active sites. Although enzyme mechanisms remain unclear despite significant interests, ligand identity and coordination structures seem to be critical factors to determine catalytic activity. We can propose synthetic routes for the design of new Mo-based catalysts from comparing structures, properties, and reactivities of metalloenzymes and artificial catalysts [14]. Although relatively less studied, Mo-clusters have shown promising electrocatalytic activities due to their intermediate behaviors between metal-coordination 
complexes and nanoparticle catalysts [15]. In the perspective of developing efficient electrocatalysts, Mo-nanomaterials, which have shown remarkable electrocatalytic activities, should be considered together. Preparation methods of Mo-nanomaterials determine their catalytic activities, and proximal atoms and electronic conditions around Mo ions are closely related to reactivities of surficial Mo ions $[16,17]$.

\section{2. $\mathrm{CO}_{2}$ Electrocatalysts}

Considering current energy systems, a drastic diminution of fossil fuel consumption seems unrealistic. However, continuous research for recycling anthropogenic $\mathrm{CO}_{2}$ will be able to provide feasible solutions to current energy and climate issues. Among various $\mathrm{CO}_{2}$ transformation methods, electrochemical conversion of $\mathrm{CO}_{2}$ may be an attractive way to be conjugated with solar/electric energy conversion reactions [18]. Mo-enzymes of the formate dehydrogenases [19] (Mo-FDH) and the carbon monoxide dehydrogenases [20] $(\mathrm{MoCu}-\mathrm{CODH})$ are the most efficient $\mathrm{CO}_{2}$-catalysts on Earth, and their synthetic models are known, albeit short of the enzyme activity [21]. Moreover, many homogeneous and heterogeneous catalysts have been developed for $\mathrm{CO}_{2}$ conversion reactions.

\subsection{Metalloenzymes with $\mathrm{CO}_{2}$ Reactivity}

\subsubsection{Formate Dehydrogenases}

Formate dehydrogenases (FDHs) is a group of metalloenzymes that catalyze a reversible conversion of formate to $\mathrm{CO}_{2}$. The $\mathrm{CO}_{2}$ reactivity of the $\mathrm{FDH}$ active site has obtained research interests because the enzyme functions near the potential of $-420 \mathrm{mV}$ vs. NHE (Normal hydrogen electrode) scarcely requiring overpotential. It is known that the reaction rate is varied by bacteria. Rhodobacter capsulatus FDH facilitates oxidation of formate to $\mathrm{CO}_{2}$ at a rate of $36.5 \mathrm{~s}^{-1}$ and the reverse direction at a rate of $1.6 \mathrm{~s}^{-1}$ [22]. Desulfovibrio desulfuricans FDH oxidized formate much more quickly at $543 \mathrm{~s}^{-1}$ and reduced $\mathrm{CO}_{2}$ at $46.6 \mathrm{~s}^{-1}$ [23]. The FDH reactivity is directly related to the active site structure, which has a Mo center surrounded by two pyranopterin-conjugated dithiolene ligand, a chalcogenide (hydroxide or sulfide) ligand, and SeCys amino acid as a sixth ligand (Figure 1). In addition, additional roles of adjacent amino acids such as Arg and His seem to be important to assist the FDH reaction by stabilizing reaction intermediates.

$$
\mathrm{CO}_{2}+2 \mathrm{e}^{-}+\mathrm{H}^{+} \leftrightarrows \mathrm{HCOO}^{-}, \mathrm{E}^{\circ \prime}=-420 \mathrm{mV}
$$

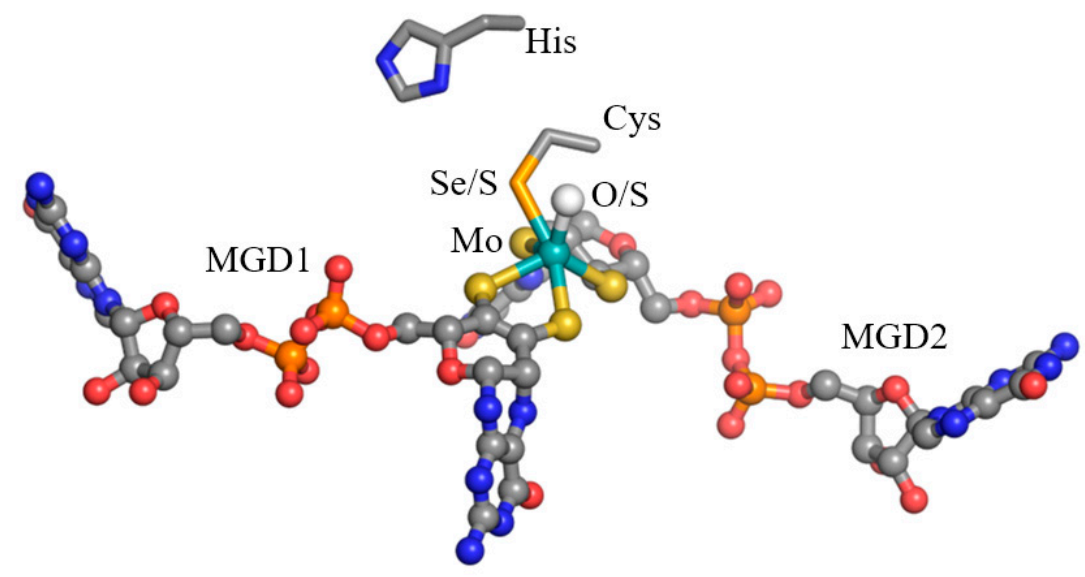

Figure 1. Oxidized form of the FDH active site from Escherichia coli (PDB 2IV2).

In 1997, Boyington and coworkers first reported the crystal structure of E. coli FDH [24]. Later, in 2006, Raaijmakers and coworkers reinterpreted the crystal structure and proposed a reaction pathway of the FDH active site (Scheme 1) [25]. They suggested that SeCys is reversibly bound to the Mo center during the redox reactions so that offers a vacant site 
to interact with substrates. Once formate bound to $\mathrm{Mo}^{6+}$ site, a proton migrated to His residue, and $\mathrm{CO}_{2}$ was released along with the reduction of $\mathrm{Mo}^{6+/ 4+}$ site. If two electrons were transferred to [4Fe4S] cluster, SeCys recombined at the Mo site. In the proposed reaction, the sulfide ligand did not participate in the reaction.

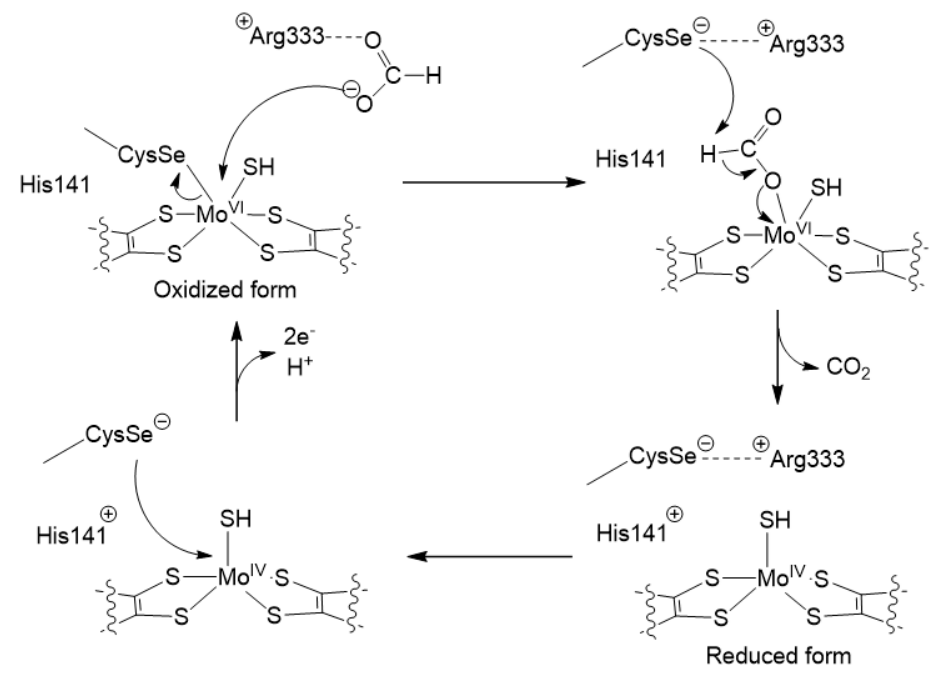

Scheme 1. A reaction pathway proposed by Raaijmakers.

Another reaction pathway including the role of sulfide ligand has been proposed (Scheme 2). In 2011, Moura and coworkers suggested that the sulfide ligand assists the reversible dissociation/association of Mo-SeCys bond on the basis of theoretical studies. A probable Mo-S-SeCys intermediate could open a coordination site to interact with formate. Once a proton migrated from formate to SeCys, a thiocarbonate intermediate was formed with the dissociation of the S-SeCys bond, and adjacent $\mathrm{Arg}^{+}$amino acid possibly stabilized the negatively charged intermediate. The roles of nearby amino acids seemed to be critical for the catalytic reaction at the active site $[26,27]$.

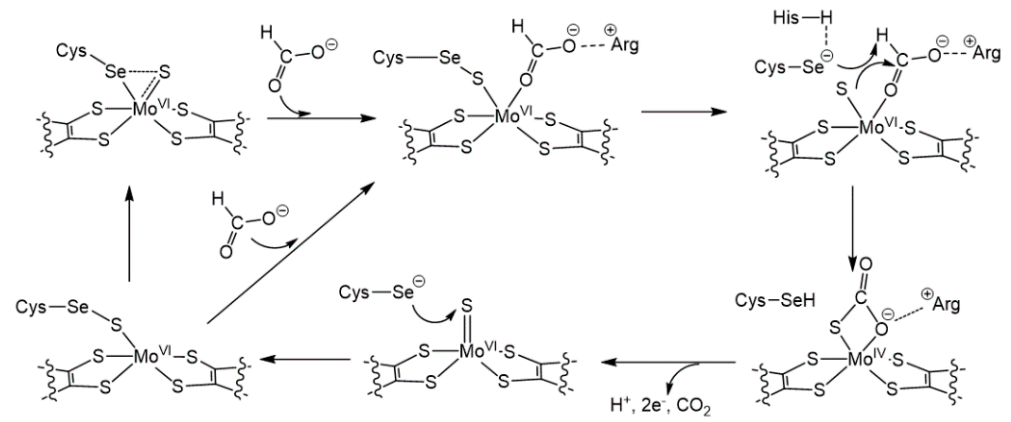

Scheme 2. A reaction pathway including the role of sulfide ligand.

The same group proposed that a hydride transfer occurred in the conversion of $\mathrm{Mo}(\mathrm{VI})=\mathrm{X}$ and $\mathrm{Mo}(\mathrm{IV})-\mathrm{XH}$, and the formate oxidation would likely occur as an indirect pathway [23]. In a substitution experiment of Mo-bound formate for isoelectronic azide, the azide entered between Arg/His and Mo=S, not at the binding site of SeCys (Scheme 3).

Haumann and coworkers reported that the $\mathrm{Mo}=\mathrm{S}$ bond length of the oxidized form is $\sim 2.16 \AA$ on the basis of X-ray absorption spectroscopy [28].

They suggested that Mo-SH possibly exists based on the Mo-S distance of $\sim 2.4 \AA$ in the X-ray crystal structure and SeCys stays apart from the Mo center during the reaction. They suggested a direct interaction of formate with Mo center based on X-ray absorption spectroscopy. When azide entered in the Mo-S $\mathrm{Cys}_{\mathrm{s}}$ site of the oxidized form, 
the Mo-Cys bond distance decreased. Conversely, when azide was removed, the Mo-Cys distance increased [29].

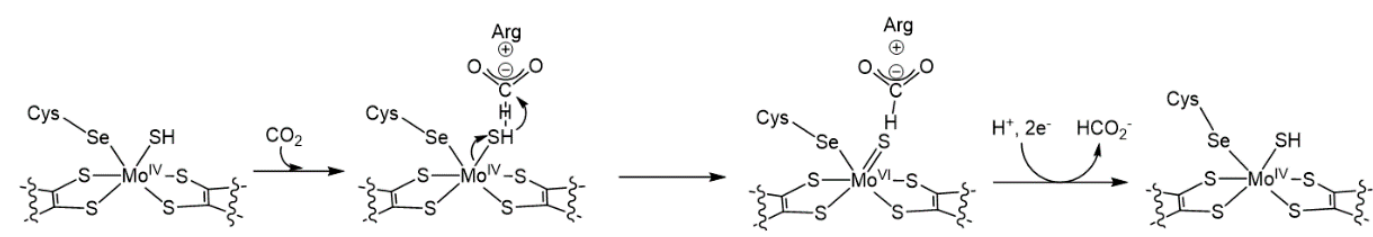

Scheme 3. Indirect reaction pathway through Mo-SH and Arg interaction.

The reaction mechanism of the FDH active site is a continuous research topic because an in-depth understanding of the active site will lead to the development of efficient electrocatalysts for $\mathrm{CO}_{2}$ conversion.

\subsubsection{MoCu-Carbon Monoxide Dehydrogenases}

In 2002, $\mathrm{MoCu}$-carbon monoxide dehydrogenase (CODH) from Oligotopha carboxidovorans was found to catalyze the oxidation of $\mathrm{CO}$ to $\mathrm{CO}_{2}$ under aerobic conditions. The enzyme exists as a dimer form of heterotrimer [30]. The hetero-trimer is composed of $88.7 \mathrm{kDa}$ L (809 residues), $30.2 \mathrm{kDa} \mathrm{M}$ (288 residues), and $17.8 \mathrm{kDa} \mathrm{S}$ (166 residues). The $\mathrm{L}$ subunit contains molybdopterin-cytosine dinucleotide (MCD), and the $\mathrm{M}$ subunit has a flavin adenine dinucleotide (FAD) cofactor. Two [2Fe-2S] clusters stay in the $\mathrm{S}$ subunit [31]. As characterized by X-ray crystallography and extended X-ray absorption fine structure (EXAFS), the MoCu-CODH active site is composed of a hetero-bimetallic cluster of (MCD) Mo ${ }^{\mathrm{VI}} \mathrm{O}\left(\mu^{2}-S\right)-\mathrm{Cu}^{\mathrm{I}}(\mathrm{S}-\mathrm{CYS})$, and the bent $\mu^{2}-\mathrm{S}$ bridge connects the $\mathrm{Cu}$ and Mo center (Figure 2a) [32]. The resting state of the active site was characterized as a $\mathrm{Mo}^{\mathrm{VI}}(\mathrm{O})_{2} \mathrm{SCu}^{\mathrm{I}}$ core, and the catalytic oxidation possibly occurs with $\mathrm{CO}$ binding at the $\mathrm{Cu}$ center.

In 2002, Dobbek and coworkers reported the X-ray structure of the MoCu-CODH with N-butylisocyanide, where the N-butylisocyanide entered between $\mu-\mathrm{S}-\mathrm{Cu}$ bond by cleaving the bridging sulfide bond [31]. Accordingly, they suggested that CO would interact with the active site in a similar way as the isoelectronic molecule as forming a $\mu$-thiocarbamate intermediate (Figure $2 b$ ).

However, Siegbahn and coworker suggested that $\mathrm{CO}$ binding to $\mathrm{Cu}$ is energetically favored from the computational studies. Next, the $\mathrm{Cu}-\mathrm{CO}$ likely experiences a nucleophilic attack by the equatorial $\mathrm{Mo}=\mathrm{O}$ to form a thiocarbamate intermediate, and $\mathrm{CO}_{2}$ can be released with coordination by $\mathrm{H}_{2} \mathrm{O}$ (or $-\mathrm{OH}$ ) (Figure 2c) [33].

The formation of a thiocarbamate intermediate was suggested previously, but Hofmann and coworkers claimed that a thiocarbamate intermediate is not relevant to the $\mathrm{MoCu}-\mathrm{CODH}$ catalytic cycle, because a thiocarbamate moiety is too stable to be involved in the catalytic steps (Figure 2d) [34]. Hille and coworkers also proposed that the $\mathrm{Cu}-\mathrm{CO}$ $\mathrm{O}-\mathrm{Mo}$ bond is formed after $\mathrm{CO}$ insertion (Figure 2e). They emphasized the role of nearby Glu763 residue to deprotonate $\mathrm{H}_{2} \mathrm{O}$. A nucleophilic attack of $-\mathrm{OH}$ to the labile equatorial $\mathrm{Mo}=\mathrm{O}$ could promote the release of $\mathrm{CO}_{2}$ [30] The aerobic $\mathrm{MoCu}-\mathrm{CODH}$ catalyzed $\mathrm{CO}$ oxidation with $k_{\text {cat }} 93.3 \mathrm{~s}^{-1}$ at $\mathrm{pH} 7.2$ condition [35].

\subsection{Structural Analogs of $\mathrm{CO}_{2}$ Enzymes}

\subsubsection{FDH Analogs}

The high efficiency of the FDH enzyme spurs researchers to synthesize structural analogs of the enzyme active site. Synthetic procedures for various dithiolene complexes enabled modeling studies of the enzyme active site having the Mo-bis(dithiolene) moiety. High-valent Mo(IV-VI)-bis(dithiolene) appeared to be highly reactive. Although the Mo enzyme active site is protected by surrounding proteins, the air-sensitivity of high-valent Mo in solution conditions makes the modeling study difficult. On the other hand, the high reactivity could be a clue to the $\mathrm{CO}_{2}$ reactivity of the Mo site. Previous studies 
have revealed that the selective reactivity of Mo-bis(dithiolene) complexes is related to auxiliary ligands.

a

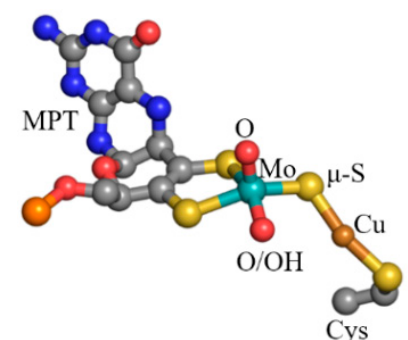

b

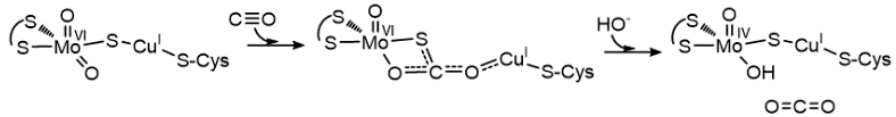

$\mathrm{c}$

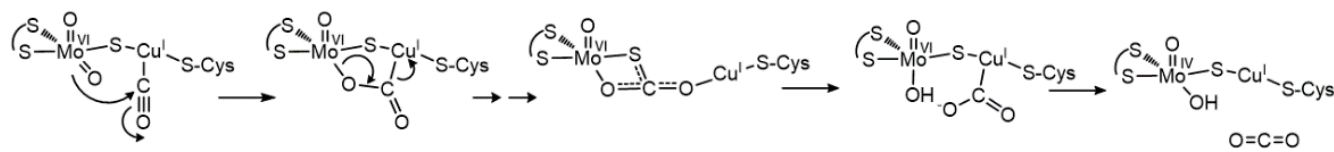

d

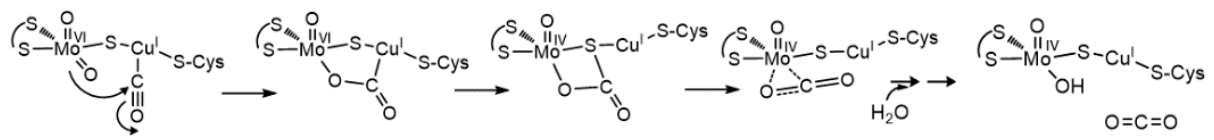

e

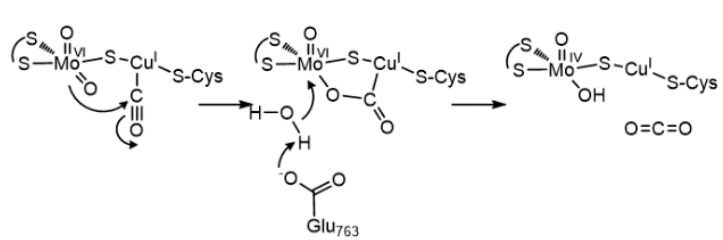

Figure 2. (a) MoCu-CODH active site (O. carboxidovorans CODH, PDB code $1 \mathrm{~N} 5 \mathrm{~W}$ ) and reaction pathways proposed by (b) Dobbek, (c) Siegbahn, (d) Hofmann, and (e) Hille.

The Mo-FDH and W-FDH active sites have very similar coordination environments except for the metal center, although their reaction conditions are different because of the bacterial habitat. In 2012, Kim and Seo reported $\mathrm{CO}_{2}$ reactivity of the in-situ generated $\left[\mathrm{W}^{\mathrm{IV}}(\mathrm{OH})\left(\mathrm{S}_{2} \mathrm{C}_{2} \mathrm{Ph}_{2}\right)_{2}\right]^{-}$(2) [36] as an example of the functional model of the W-FDH active site (Scheme 4) [25]. Complex 2 generated by hydrolysis of $\left[\mathrm{W}^{\mathrm{IV}}(\mathrm{OPh})\left(\mathrm{S}_{2} \mathrm{C}_{2} \mathrm{Ph}_{2}\right)_{2}\right]^{-}$ (1) $[37,38]$ showed the $\mathrm{CO}_{2}$ reactivity at mild condition, and it was suggested that a nucleophilic attack of $-\mathrm{OH}$ to $\mathrm{CO}_{2}$ formed a $\mathrm{W}$-(bi)carbonate intermediate. Although the model complex did not show a catalytic activity, the plausible formation of a W-(bi)carbonate intermediate was similar to the reactivity of the FDH active site [26]. They also reported a stoichiometric reduction of $\mathrm{CO}_{2}$ to formate by $\left[\mathrm{W}^{\mathrm{IV}} \mathrm{O}\left(\mathrm{S}_{2} \mathrm{C}_{2} \mathrm{Me}_{2}\right)_{2}\right]^{2-}$ (3) at $90{ }^{\circ} \mathrm{C}$ [39]. A W-carbonate intermediate was suggested as an intermediate before the $\mathrm{CO}_{2}$ reduction, but the oxidized $W$ complex was dimerized to $\left[\mathrm{W}_{2}{ }_{2} \mathrm{O}_{2}(\mu-S)\left(\mu-\mathrm{S}_{2} \mathrm{C}_{2} \mathrm{Me}_{2}\right)\left(\mathrm{S}_{2} \mathrm{C}_{2} \mathrm{Me}_{2}\right)_{2}\right]^{2-}$ (4) at the high temperature as frustrating catalytic reaction (Scheme 4).

Fontecave and coworkers reported catalytic $\mathrm{CO}_{2}$ reduction by Ni-bis(dithiolene) complex using a dithiolene derivative of quinoxaline-pyran-fused dithiolene (qpdt ${ }^{2-}$ ), which is similar to the molybdopterin (MPT) structure of the FDH active site (Scheme 4) [40]. In 2018, they used the qpdt ${ }^{2-}$ ligand to prepare Mo complexes, $\mathrm{Mo}^{\mathrm{IV}} \mathrm{O}(\mathrm{qpdt})_{2}(5),\left[\mathrm{Mo}^{\mathrm{IV}} \mathrm{O}(\mathrm{H}-\right.$ qpdt $\left.)_{2}\right]^{2-}(6)$, and $\left[\mathrm{Mo}^{\mathrm{V}} \mathrm{O}(2 \mathrm{H}-\mathrm{qpdt})_{2}\right]^{-}(7)$, as the Mo-FDH models, and examined the photocatalytic $\mathrm{CO}_{2}$ reduction activity [41]. The reduced forms of H-qpdt and $2 \mathrm{H}$-qpdt had similar oxidation states with the MPT. Using $\left[\mathrm{Ru}(\mathrm{bpy})_{3}\right]^{2+}$ photosensitizer, 1,3-dimethyl-2phenyl-2,3-dihydro-1H-benzoimidazole as a sacrificial electron donor in the solution of 
triethanolamine and acetonitrile (1:5), and irradiation with a $300 \mathrm{~W}$ Xe lamp on the Mo complex solutions afforded $\mathrm{CO}_{2}$-derivated products $\left(\mathrm{CO}\right.$ and $\left.\mathrm{HCO}_{2} \mathrm{H}\right)$ and $\mathrm{H}_{2}$. Complex 5 gave the $\mathrm{CO}_{2}$-reduction products with $19 \%$ and mostly $\mathrm{H}_{2}(81 \%)$. However, complex 6 increased the $\mathrm{CO}_{2}$-reduction yield to $47 \%$, and complex 7 provided the $\mathrm{CO}_{2}$-reduction products in the highest yield of $58 \%$ with over 100 turnover number (TON) for $68 \mathrm{~h}$.

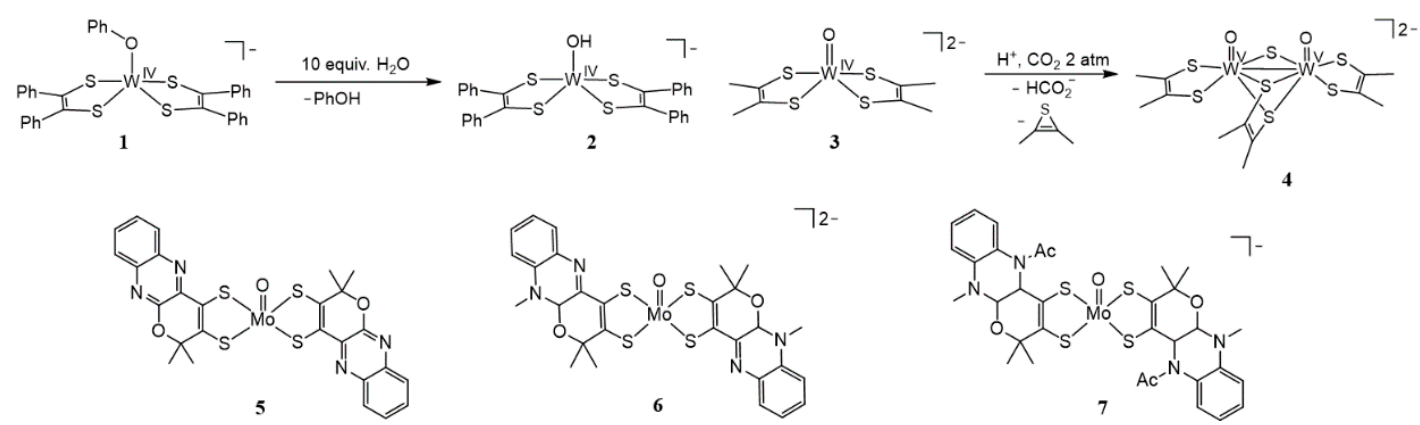

Scheme 4. FDH model complexes.

Structural and functional analogs of the FDH active sites have been reported with rare examples; however, the catalytic activities remain much less than the enzymes. Secondary coordination ligands mimicking amino acids surrounding the enzyme active site would give new catalyst designs to achieve similar activities as the enzyme.

\subsection{2. $\mathrm{MoCu}-\mathrm{CODH}$ Analogs}

In 2020, Mougel and coworkers synthesized $\left[(\mathrm{bdt}) \mathrm{Mo}(\mathrm{O}) \mathrm{S}_{2} \mathrm{CuCN}^{2-}(\mathbf{8})(\mathrm{bdt}=\mathrm{ben}-\right.$ zenedithiolate) as a MoCu-CODH model complex (Scheme 5) [42]. The Mo and Cu were bridged by $\mu^{2}$-sulfide ligand as the enzyme active site, and a bdt ligand was used to model the MPT. Complex 8 showed a catalytic reduction peak at $\mathrm{E}_{1 / 2}=-2.07 \mathrm{~V}$ vs. $\mathrm{Fc}^{+} / \mathrm{Fc}$ in $\mathrm{CO}_{2}$-saturated acetonitrile. Controlled potential electrolysis $(\mathrm{CPE})$ at $-2.62 \mathrm{~V} \mathrm{vs} . \mathrm{Fc}^{+} / \mathrm{Fc}$ in the presence of $0.1 \mathrm{M}$ 2,2,2-trifluoroethanol (TFE) produced the reaction products of formate (Faradaic efficiency $(\mathrm{FE})=69 \%), \mathrm{CO}(8 \%)$ and $\mathrm{H}_{2}(19 \%)$. It was a rare example to describe the $\mathrm{MoCu}-\mathrm{CODH}$ model with the $\mathrm{CO}_{2}$ reduction activity, although the $\mathrm{MoCu}-\mathrm{CODH}$ enzyme previously showed only the CO oxidation activity [20].
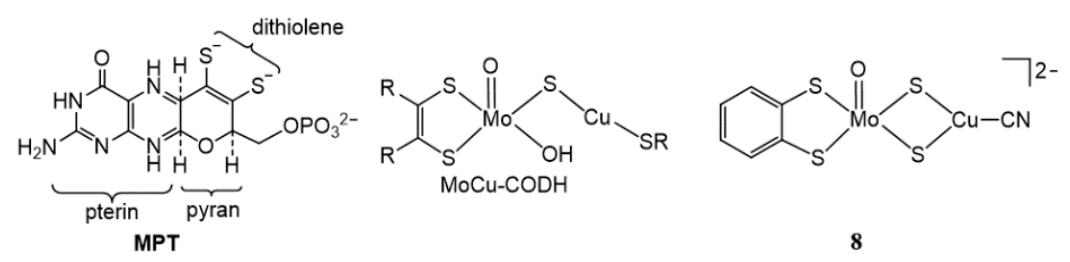

Scheme 5. MoCu-CODH active site and the model complex.

\subsection{Synthetic Electrocatalysts for $\mathrm{CO}_{2}$ Reduction}

2.3.1. Homogeneous Mo Complexes for $\mathrm{CO}_{2}$ Reduction

In 1978, Reichert and coworkers reported the $\mathrm{CO}_{2}$ reactivity of a dinuclear $\mathrm{Mo}_{2}\left(\mathrm{O}^{\mathrm{t}} \mathrm{Bu}\right)_{6}$ (9) [43]. Two $\mathrm{CO}_{2}$ molecules were reversibly inserted into the Mo-O ${ }^{t} \mathrm{Bu}$ bonds to form $\mathrm{Mo}_{2}\left(\mathrm{O}_{2} \mathrm{CO}^{t} \mathrm{Bu}\right)_{2}\left(\mathrm{O}^{t} \mathrm{Bu}\right)_{4}$ (Scheme 6) (10). From the X-ray structure, the Mo-Mo triple bond, bridged by two $\mathrm{O}_{2} \mathrm{CO}^{t} \mathrm{Bu}$, was measured to be $2.241 \AA$. The $\mathrm{CO}_{2}$ insertion occurred in both the solid and liquid states of the complex, and sublimation of the $\mathrm{CO}_{2}$ adduct at $100{ }^{\circ} \mathrm{C}$ afforded back the complex 9 by releasing $\mathrm{CO}_{2}$. 


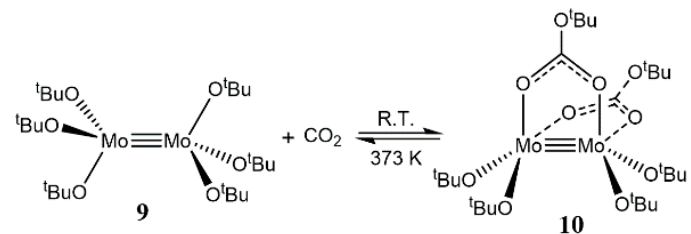

Scheme 6. $\mathrm{CO}_{2}$ reactivity of $\mathrm{Mo}_{2}\left(\mathrm{O}^{\mathrm{t}} \mathrm{Bu}\right)_{6}$ complex.

Metal ligand cooperation (MLC) is a useful method to fixate $\mathrm{CO}_{2}$. The trans- $\mathrm{Mo}\left(\mathrm{C}_{2} \mathrm{H}_{4}\right)_{2}\left(\mathrm{PMe}_{3}\right)_{4}$ (11) reacted with $\mathrm{CO}_{2}$ under mild conditions [44], where $\mathrm{CO}_{2}$ was inserted into Mo-ethylene bond to form a Mo-acrylate moiety in $\left[\mathrm{Mo}\left(\mathrm{H}_{2} \mathrm{CCHCO}_{2} \mathrm{H}\right)\left(\mathrm{C}_{2} \mathrm{H}_{4}\right)\left(\mathrm{PMe}_{3}\right)_{2}\right]_{2}$ (Scheme 7) (12). The acrylate frequency was measured as $1500 \mathrm{~cm}^{-1}$ and the ${ }^{13} \mathrm{C}$ NMR (Nuclear magnetic resonance) chemical shift at $175-180 \mathrm{ppm}$. Complex 11 reacted with a stoichiometric amount of $\mathrm{CO}_{2}$ under $1 \mathrm{~atm}$ to give 12, which could be converted back to $\mathbf{1 1}$ by treatment of $\mathrm{n}$ - $\mathrm{BuLi}$ under $\mathrm{H}_{2}$ with concomitant $\mathrm{LiO}_{2} \mathrm{CCH}_{2} \mathrm{CH}_{3}$ product. In another MLC type reaction, a PNP-amide-assisted $\mathrm{CO}_{2}$ fixation was shown with $\mathrm{Mo}(\mathrm{NO})(\mathrm{CO})(\mathrm{PNP})(13)$ $\left(\mathrm{PNP}=\mathrm{N}\left(\mathrm{CH}_{2} \mathrm{CH}_{2} \mathrm{PiPr}_{2}\right)_{2}\right)$ [45]. Complex 13 converted stoichiometric amount of $\mathrm{CO}_{2}$ to formate in the presence of $\mathrm{Na}\left[\mathrm{N}\left(\mathrm{SiMe}_{3}\right)_{2}\right]$ and additional base of $\mathrm{DBU}, \mathrm{Et}_{3} \mathrm{~N}$ (Scheme 7). However, high pressure of $\mathrm{CO}_{2}(10 \mathrm{bar})$ and $\mathrm{H}_{2}(70 \mathrm{bar})$ was also required. The MLC method effectively lowered the binding energy of $\mathrm{CO}_{2}$ to Mo complex, but the formation of a highly stable ML- $\mathrm{CO}_{2}$ adduct rather prevented the catalytic cycle.

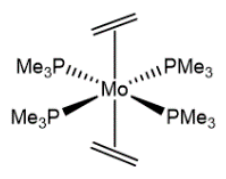

11

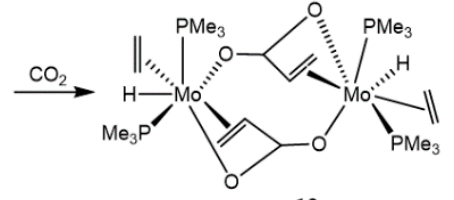

12

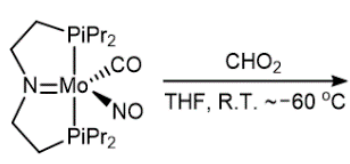

13

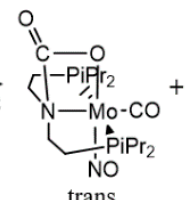

trans

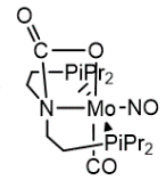

cis

Scheme 7. Metal ligand cooperation (MLC) complexes with $\mathrm{CO}_{2}$ reactivity.

Lau and coworkers utilized hetero-bimetallic systems of early/late transition metal ions for electrocatalytic reactions. They synthesized $\left(\eta^{5}-\mathrm{C}_{5} \mathrm{H}_{5}\right) \mathrm{Ru}(\mathrm{CO})\left(\mu\right.$-dppm) $\mathrm{Mo}(\mathrm{CO})_{2}\left(\eta^{5}-\mathrm{C}_{5} \mathrm{H}_{5}\right)$ (14) (Scheme 8) from a reaction of $\left(\eta^{5}-\mathrm{C}_{5} \mathrm{H}_{5}\right) \mathrm{Ru}(\mathrm{dppm}) \mathrm{Cl}$ and $\mathrm{Na}\left[\left(\eta^{5}-\mathrm{C}_{5} \mathrm{H}_{5}\right) \mathrm{Mo}(\mathrm{CO})_{3}\right]$ [46]. Complex 14 promoted catalytic $\mathrm{CO}_{2}$ reduction to formic acid at $120^{\circ} \mathrm{C}$ with $43 \mathrm{TON}$ per catalyst for $45 \mathrm{~h}$ in benzene containing triethylamine base. Interestingly, the same complex also promoted converse conversion of formic acid to $\mathrm{CO}_{2}$ and $\mathrm{H}_{2}$ at $80^{\circ} \mathrm{C}$. They suggested a hydride-bridged bimetallic species is formed as a reaction intermediate on the basis of a hydride detection at $-17.16 \mathrm{ppm}$ by ${ }^{1} \mathrm{H}$ NMR spectroscopy.

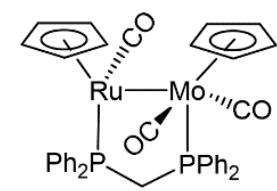

14

Scheme 8. Heterobimetallic $\left(\eta^{5}-\mathrm{C}_{5} \mathrm{H}_{5}\right) \mathrm{Ru}(\mathrm{CO})\left(\mu\right.$-dppm) $\mathrm{Mo}(\mathrm{CO})_{2}\left(\eta^{5}-\mathrm{C}_{5} \mathrm{H}_{5}\right)$ complex.

Minato and coworkers synthesized a series of Mo-silyl hydrido complexes of $\left[\mathrm{MoH}_{3}\right.$ $\left.\left(\left[\mathrm{Ph}_{2} \mathrm{PCH}_{2} \mathrm{CH}_{2} \mathrm{P}(\mathrm{Ph})-\mathrm{C}_{6} \mathrm{H}_{4}-\mathrm{o}\right]_{2}(\mathrm{R}) \mathrm{Si}-\mathrm{P}, \mathrm{P}, \mathrm{P}, \mathrm{P}, \mathrm{Si}\right)\right]\left(\mathrm{R}=\mathrm{Ph}(\mathbf{1 5 a}), \mathrm{C}_{6} \mathrm{~F}_{5}(\mathbf{1 5 b}), 4-\mathrm{Me}_{2} \mathrm{NC}_{6} \mathrm{H}_{4}\right.$ (15c), cyclohexyl (15d), and $n-\mathrm{C}_{6} \mathrm{H}_{13}$ (15e)) [47]. Silyl ligands with a strong trans effect were employed to control the reactivity of the Mo center (Scheme 9) [48,49]. The RSi-Mo could make an open coordination site at trans position to allow binding of electrophilic molecules such as $\mathrm{O}_{2}, \mathrm{CO}_{2}$, and carboxylic acid. Under the reaction conditions of $2.0 \mathrm{M}$ of dimethylamine, $30 \mathrm{~atm}$ of $\mathrm{CO}_{2}$, and $20 \mathrm{~atm}$ of $\mathrm{H}_{2}$, complexes $15 \mathrm{a}-\mathbf{e}$ catalyzed the $\mathrm{CO}_{2}$ hydration as producing $\mathrm{N}, \mathrm{N}$-dimethylformamide $(\mathrm{DMF})$ and $\mathrm{H}_{2} \mathrm{O}$. The catalytic conversion of $\mathrm{CO}_{2}$ to DMF could be controlled by the Si-substituent. The complex 15a with a Si-phenyl 
moiety achieved 92 TON per catalyst, but complex $\mathbf{1 5 b}$ with $\mathrm{Si}-\mathrm{C}_{6} \mathrm{~F}_{5}$ showed only 1 TON. Electron donating substituent increased TON of complexes as seen with $15 \mathrm{c}(\mathrm{TON}=130)$ and 15e (110), because the stronger trans effect assisted binding of substrates to increase the catalytic reactivity.

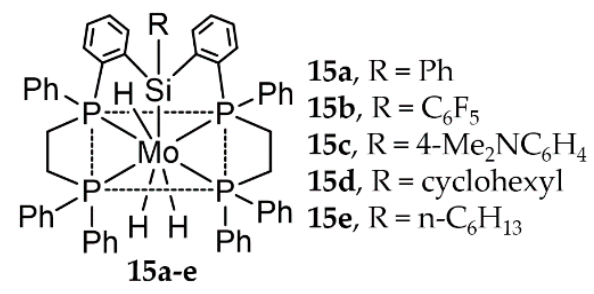

Scheme 9. Mo-silyl hydrido complexes.

Redox-active ligand could assist central metal ions for reductive $\mathrm{CO}_{2}$ reactions. Trovitch and coworkers have used bis(imino)pyridine ligand for hydrosilylations of ketones [50]. They synthesized ( $\left.\kappa^{6}-\mathrm{P}, \mathrm{N}, \mathrm{N}, \mathrm{N}, \mathrm{C}, \mathrm{P}-\mathrm{Ph} 2 \mathrm{PPr} \mathrm{PDI}\right)-\mathrm{MoH}$ (17) (PDI = pyridine diamine) by a reduction of (( $\left.{ }^{\mathrm{Ph} 2 \mathrm{PPr} P D I) M o I}\right) \mathrm{I}(\mathbf{1 6})$ with excess K/Hg (Scheme 10) [51]. Complex 17 reacted with $\mathrm{CO}_{2}$ under 0.2 atm of $\mathrm{CO}_{2}$ condition, where $\mathrm{CO}_{2}$ was inserted into Mo-H bond to form $\eta^{1}$-formate-bound $\mathrm{Mo}(\mathrm{OC}(\mathrm{O}) \mathrm{H})$ species [52,53]. The Mo-formate ${ }^{13} \mathrm{C}$ NMR resonance appeared at $169.7 \mathrm{ppm}$ and the infrared (IR) frequency was detected at $1625 \mathrm{~cm}^{-1}$. Complex 17 also promoted a catalytic conversion of HBPin to $\mathrm{H}_{3} \mathrm{COBPin}$ and $\mathrm{O}$ (BPin) $)_{2}$ under $1 \mathrm{~atm}$ of $\mathrm{CO}_{2}$ as recording $40.4 \mathrm{~h}^{-1}$ turnover frequency (TOF) and $323 \mathrm{TON}$ with consuming 97\% of HBPin. Distillation of $\mathrm{H}_{3} \mathrm{COBPin}$ in water for $24 \mathrm{~h}$ generated $\mathrm{MeOH}$, eventually producing $58 \%$ of $\mathrm{MeOH}$ starting from HBPin. They showed a potential pathway to convert $\mathrm{CO}_{2}$ to methanol. Kubiak and coworkers used bipyridine (bpy) ligands to prepare Mo-carbonyl complexes, $\mathrm{Mo}(\mathrm{bpy})(\mathrm{CO})_{4}(\mathbf{1 8 a})$ and $\mathrm{Mo}(\mathrm{bpy}-\mathrm{tBu})(\mathrm{CO})_{4}(\mathbf{1 8 b})$ [54]. Complexes 18a and $\mathbf{1 8 b}$ showed electrocatalytic $\mathrm{CO}_{2}$ reduction activity in acetonitrile solution [55]. Complex 18a had a reversible redox couple at $-1.58 \mathrm{~V}$ vs. SCE (saturated calomel electrode) and an irreversible wave at $-2.14 \mathrm{~V}$ vs. SCE, and catalyzed $\mathrm{CO}_{2}$ reduction near the second reduction potential. Complex $\mathbf{1 8 b}$ shifted the reduction potential a bit negatively to $-2.20 \mathrm{~V}$ vs. SCE. The addition of $1.6 \mathrm{M}$ of TFE into the reaction solutions generated only $\mathrm{CO}$ product as recording $1.0 \mathrm{~s}^{-1}$ TOF with 18a and $1.9 \mathrm{~s}^{-1}$ with $\mathbf{1 8 b}$.

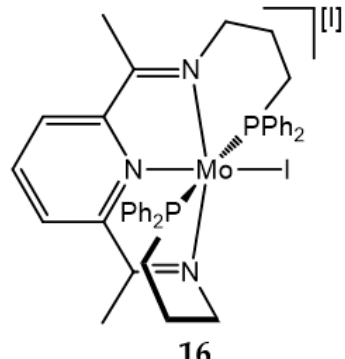

16

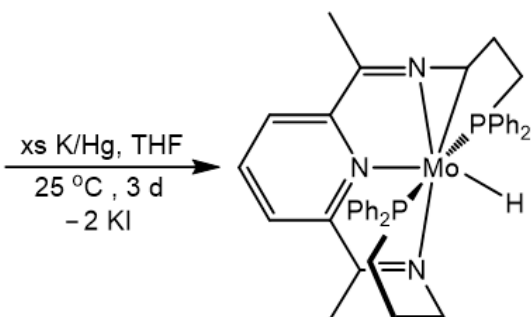

17<smiles></smiles>

18a, $\mathrm{R}=\mathrm{H}$ $18 \mathrm{~b}, \mathrm{R}={ }^{\mathrm{t}} \mathrm{Bu}$

Scheme 10. Redox active ligand assisted Mo complexes.

Bernskoetter and coworkers used tertiary amine pincer type ligands to prepare $\mathrm{CO}_{2}$ hydrogenation catalysts [56]. Reduction of $\left(\mathrm{PN}^{\mathrm{Me}} \mathrm{P}\right) \mathrm{MoCl}_{3}$ with $\mathrm{Na}(\mathrm{Hg})$ under ethylene afforded $\left(\mathrm{PN}^{\mathrm{Me}} \mathrm{P}\right) \mathrm{Mo}\left(\mathrm{C}_{2} \mathrm{H}_{4}\right)_{2}(\mathbf{1 9})$, and the following oxidative $\mathrm{C}-\mathrm{H}$ addition generated the Mo-H species of $\left(\mathrm{PN}^{\mathrm{CH}} \mathrm{P}\right) \mathrm{MoH}\left(\mathrm{C}_{2} \mathrm{H}_{4}\right)_{2}$ (20) (Scheme 11) [57]. Blowing 4 equiv. of $\mathrm{CO}_{2}$ into complex 20 gave the $\mathrm{Mo}-\mathrm{O}_{2} \mathrm{CH}$ moiety in complex 21. Catalytic production of formate was achieved by using LiOTF as cocatalyst and DBU base under 69 atm of $\mathrm{H}_{2}$ and $\mathrm{CO}_{2}(1: 1$ ratio) at $100{ }^{\circ} \mathrm{C}$ as recording $35 \mathrm{TON}$ for $16 \mathrm{~h}$. 


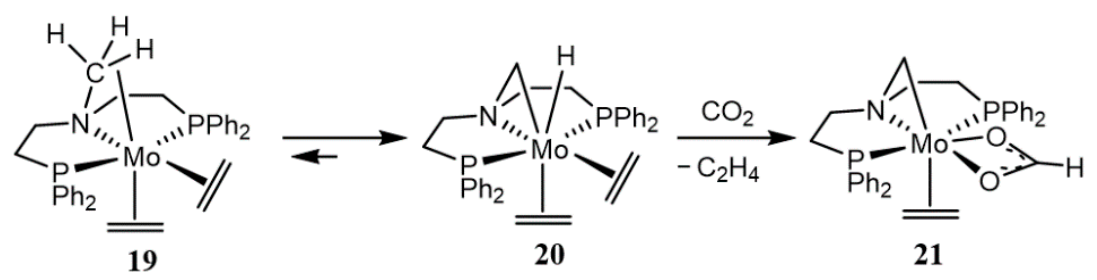

Scheme 11. $\mathrm{CO}_{2}$ reactivity of $\left(\mathrm{PN}^{\mathrm{Me}} \mathrm{P}\right) \mathrm{Mo}\left(\mathrm{C}_{2} \mathrm{H}_{4}\right)_{2}$ complex.

The low-valent Mo complexes have shown promising activities for $\mathrm{CO}_{2}$, but the formation of relatively stable adducts or requirement of high-pressure conditions remain issues to solve for efficient catalyst development.

\subsubsection{Heterogeneous Mo-Containing $\mathrm{CO}_{2}$ Reduction Electrocatalysts}

In 1986, Frese and coworkers reported the reduction of $\mathrm{CO}_{2}$ to methanol using Mo electrode at the potential range of -0.57 to $-0.67 \mathrm{~V}$ vs. SCE in $\mathrm{CO}_{2}$-saturated aqueous media ( $\left.0.05 \mathrm{M} \mathrm{H}_{2} \mathrm{SO}_{4}, \mathrm{pH} 4.2\right)$ [58]. As a result, $18 \mu \mathrm{mol}$ of methanol was obtained for $40 \mathrm{~h}$ with $50 \%$ FE together with $0.044 \mu \mathrm{mol}$ of $\mathrm{CO}$ production.

$\mathrm{MoS}_{2}$ surface has shown $\mathrm{CO}_{2}$ reduction ability, but in general, the intrinsic properties such as poor electrical conductivity and few active sites cause low electrocatalytic activity. In 2014, Asadi and coworkers reported the layer-stacked $\mathrm{MoS}_{2}$ nanomaterial [59]. The $\mathrm{MoS}_{2}$ surface conducted selective reduction of $\mathrm{CO}_{2}$ to $\mathrm{CO}$ in the presence of $4 \%$ 1-ethyl3-methylimidazolium tetrafluoroborate $\left(\mathrm{EMIM}^{-} \mathrm{BF}_{4}\right)$ with a high reduction current of $65 \mathrm{~mA} / \mathrm{cm}^{2}$ at $-0.76 \mathrm{~V}$ vs. RHE (FE $\sim 98 \%$ ). The activity at a low overpotential $(0.1 \mathrm{~V})$ was measured to be 25 times higher than Au nanoparticles. They reported vertically aligned (VA) $\mathrm{MoS}_{2}$ had higher $\mathrm{CO}_{2}$ reactivity than bulk $\mathrm{MoS}_{2}$. The high catalytic performance was due to the increased $\mathrm{MoS}_{2}$ edge site. In 2017, Salehi-Khojin and coworkers synthesized VA-MoS 2 with $\sim 20 \mathrm{~nm}$ thickness by chemical vapor diffusion (CVD) method, and they also studied the metal-doping effect for the $\mathrm{CO}_{2}$ reduction activity [60]. The $5 \% \mathrm{Nb}$-doped VA- $\mathrm{MoS}_{2}$ began the $\mathrm{CO}_{2}$ reduction with onset overpotential of $31 \mathrm{mV}$, and it reached $237 \mathrm{~mA} / \mathrm{cm}^{2}$ current density at $-0.8 \mathrm{~V}$ vs. RHE. However, Ta-doped (3 18\% Ta) VA$\mathrm{MoS}_{2}$ showed $98-68 \mathrm{~mA} / \mathrm{cm}^{2}$ at $-0.8 \mathrm{~V}$ vs. RHE, which was rather lower than a pristine VA-MoS $2\left(121 \mathrm{~mA} / \mathrm{cm}^{2}\right)$.

Previously, Bi-deposited glassy carbon has shown a good catalytic activity for reduction of $\mathrm{CO}_{2}$ to $\mathrm{CO}$ because $\mathrm{CO}_{2}{ }^{\bullet-}$ radical species are well stabilized on Bi site [61]. Interestingly, a formation of hetero-bimetallic $\mathrm{MoBiS}_{\mathrm{x}}(\mathrm{Mo} / \mathrm{Bi} 1: 1)$ nanosheet showed different $\mathrm{CO}_{2}$ reduction product of methanol (FE 71.2\%) with generation of side products of methane $(7.8 \%) \mathrm{CO}(9.6 \%) \mathrm{H}_{2}(11.4 \%)$ [62]. It was observed that, if the Bi ratio was raised, the $\mathrm{CO}$ percentage increased. They explained that the further reduction process is probably promoted by the synergistic effect with $\mathrm{MoS}_{\mathrm{x}}$-catalytically active for the proton reduction.

Nano-sized $\mathrm{Cu}$ particles have shown $\mathrm{CO}_{2}$-to-hydrocarbon electrocatalytic reduction activity [63]. The Cu-doping effect on the $\mathrm{CO}_{2}$ reactivity of $\mathrm{MoS}_{2}$ was studied by $\mathrm{Yu}$ and coworkers [64]. Flower-like $\mathrm{MoS}_{2}$ was prepared by hydrothermal method, and the surface was reacted with $\mathrm{Cu}\left(\mathrm{NO}_{3}\right)_{2} \cdot 3 \mathrm{H}_{2} \mathrm{O}$ to give $\mathrm{Cu} / \mathrm{MoS}_{2}$ composite with varying the $\mathrm{Cu} / \mathrm{Mo}$ ratio. Specific $\mathrm{Cu}$ ratio (12.76\%) exhibited four times higher catalytic current density at $-1.7 \mathrm{~V}$ vs. SCE than a bare $\mathrm{MoS}_{2}$ as producing $\mathrm{CO}(\mathrm{FE}=35.19 \%), \mathrm{CH}_{4}(17.08 \%), \mathrm{C}_{2} \mathrm{H}_{4}$ $(2.93 \%)$. The high Faradaic efficiency for $\mathrm{CO}_{2}$ reduction was because the surface-deposited $\mathrm{Cu}$ enhanced the electronic conductivity and $\mathrm{CO}_{2}$ adsorption ability of $\mathrm{MoS}_{2}$.

Few active sites have been an issue for the preparation of $\mathrm{MoS}_{2}$ electrodes, thus, synthetic methods are pursued to enlarge the $\mathrm{MoS}_{2}$ edge site area. Wang and coworkers used zeolitic imidazolate frameworks to prepare hollow $\mathrm{MoS}_{2}$ nanostructure, which effectively enlarged the exposed $\mathrm{MoS}_{2}$ edge area. The edge-exposed $\mathrm{MoS}_{2}$ was supported by $\mathrm{N}$-doped carbon to improve electron transfer, which gave two times higher current density $\left(34.31 \mathrm{~mA} / \mathrm{cm}^{2}\right.$ at $-0.7 \mathrm{~V}$ vs. RHE) and 1.4 times higher $\mathrm{FE}\left(\mathrm{CO}_{2}\right.$-to-CO $\left.93 \% \mathrm{FE}\right)$ compared to $\mathrm{MoS}_{2}$ [65]. The $\mathrm{N}$-doped carbon served as efficient conductive support, because the more 
electronegative $\mathrm{N}$ atom decreases electron density at nearby carbon sites by improving electron transfer at the electrode surface. An enhanced surface electron transfer to $\mathrm{MoS}_{2}$ edge could lower the energy barrier for the formation of $\mathrm{CO}_{2}$ reduction intermediates on the catalytic site [66]. Zhu and coworkers prepared N-doped $\mathrm{MoS}_{2}$ nanosheets on $\mathrm{N}$-doped carbon nanodots (N-MoS $\left.{ }_{2} @ \mathrm{NCDs}\right)$ through a solvothermal method [66]. N-MoS $\mathrm{M}_{2} @ \mathrm{NCDs}$ loaded on glassy carbon electrode exhibited high catalytic activity for the $\mathrm{CO}_{2}$ reduction to $\mathrm{CO}$ as recording $36 \mathrm{~mA} / \mathrm{cm}^{2}$ at $-0.9 \mathrm{~V}$ vs. $\mathrm{RHE}(90 \% \mathrm{FE})$.

The selection of electrolytes is also a critical factor to improve $\mathrm{CO}_{2}$ reduction efficiency. EMIM-BF 4 electrolyte was shown to increase selectivity for $\mathrm{CO}$ product from $\mathrm{CO}_{2}$ reduction [59]. Salehi-Khojin and coworkers reported that the use of a hybrid electrolyte of choline chloride/ $\mathrm{KOH}$ was also effective to improve the $\mathrm{CO}_{2}$ reduction selectivity of the $\mathrm{MoS}_{2}$ electrode [67]. Using the choline chloride/ $\mathrm{KCl}$ buffer instead of EMIM-BF 4 afforded 1.5 times higher current density at $-0.25 \mathrm{~V}$ vs. RHE. The high catalytic activity was related to an accumulation of small size $\mathrm{K}^{+}$ion on the $\mathrm{MoS}_{2}$ surface, which allowed exposure of the $\mathrm{MoS}_{2}$ edge site.

Xie and coworkers devised MoS/Se alloy monolayer to induce poor overlapping of frontier orbitals, which was helpful to enhance the surface activity for the $\mathrm{CO}_{2}$ reduction [68]. The MoS/Se alloy monolayer improved CO production efficiency with $45 \%$ FE at $-1.15 \mathrm{~V}$ vs. RHE compared to $\mathrm{MoS}_{2}(17 \%)$ and $\mathrm{MoSe}_{2}(31 \%)$ monolayer. On the other hand, in the report by Han and coworkers, the replacement of the chalcogenide with phosphide gave different $\mathrm{CO}_{2}$ reduction products. $\mathrm{MoP}$ nanoparticle as supported by In-doped porous carbon (In-PC) converted $\mathrm{CO}_{2}$ to formic acid as recording $43.8 \mathrm{~mA} / \mathrm{cm}^{2}$ at $-2.2 \mathrm{~V}$ vs. $\mathrm{Ag} / \mathrm{AgNO}_{3}$ with $97 \% \mathrm{FE}[69]$.

In a rare example, a Mo-cluster has shown promising photocatalytic $\mathrm{CO}_{2}$ reduction ability under visible light illumination. Hexanuclear $\left[\mathrm{Mo}_{6} \mathrm{Br}_{14}\right]^{2-}$ clusters [70] immobilized on graphene oxide [71] showed photocatalytic $\mathrm{CO}_{2}$ reduction to methanol. High nuclearity transition metal cluster of $\left[\mathrm{Mo}_{6} \mathrm{X}_{8}{ }_{8} \mathrm{~L}_{6}{ }_{6}\right]^{2-}\left(\mathrm{X}^{\mathrm{i}}=\right.$ inner, $\mathrm{L}^{\mathrm{a}}=$ apical $)$ enabled visible light activities due to delocalized valence electrons overall metal centers [72,73]. The catalytic $\mathrm{CO}_{2}$ reduction activities of the Mo-based electrocatalysts are compared in Table 1.

Table 1. Compared $\mathrm{CO}_{2}$ reduction catalytic efficiencies of Mo-based electrocatalysts.

\begin{tabular}{|c|c|c|c|c|}
\hline Catalyst & FE & Current Density & $\begin{array}{l}\mathrm{CO}_{2} \text { Reduction } \\
\text { Product (Major) }\end{array}$ & Ref. \\
\hline Mo electrode & $50 \%$ & - & Methanol & [58] \\
\hline layer-stacked $\mathrm{MoS}_{2}$ & $\sim 98 \%$ & $-65 \mathrm{~mA} / \mathrm{cm}^{2}$ at $-0.76 \mathrm{~V}$ vs. RHE & $\mathrm{CO}$ & [59] \\
\hline $5 \% \mathrm{Nb}$-doped VA-MoS 2 & $82 \%$ & $-237 \mathrm{~mA} / \mathrm{cm}^{2}$ at $-0.8 \mathrm{~V}$ vs. RHE & $\mathrm{CO}$ & [60] \\
\hline Ta-doped VA-MoS 2 & - & $-98 \sim 68 \mathrm{~mA} / \mathrm{cm}^{2}$ at $-0.8 \mathrm{~V}$ vs. RHE & $\mathrm{CO}$ & [60] \\
\hline MoBiS $_{x}$ nanosheets & $71 \%$ & $-12.1 \mathrm{~mA} / \mathrm{cm}^{2}$ at $-0.7 \mathrm{~V}$ vs. SHE & Methanol & [62] \\
\hline MoS/Se monolayer & $45 \%$ & $-43 \mathrm{~mA} / \mathrm{cm}^{2}$ at $-1.15 \mathrm{~V}$ vs. RHE & $\mathrm{CO}$ & [68] \\
\hline $\mathrm{Cu}$-doped $\mathrm{MoS}_{2}$ & $85 \%$ & $-17 \mathrm{~mA} / \mathrm{cm}^{2}$ at $-1.7 \mathrm{~V}$ vs. SCE & $\mathrm{CO}$ & [64] \\
\hline NCMSH & $93 \%$ & $-34.31 \mathrm{~mA} / \mathrm{cm}^{2}$ at $-0.7 \mathrm{~V}$ vs. RHE & $\mathrm{CO}$ & [65] \\
\hline $\begin{array}{l}\mathrm{MoS}_{2} \text { nanoflake } \\
\text { (choline chloride) }\end{array}$ & $93 \%$ & $-315 \mathrm{~mA} / \mathrm{cm}^{2}$ at $-0.8 \mathrm{~V}$ vs. RHE & $\mathrm{CO}$ & [67] \\
\hline $\mathrm{N}-\mathrm{MoS}_{2} @ \mathrm{NCDs}$ & $90 \%$ & $-36 \mathrm{~mA} / \mathrm{cm}^{2}$ at $-0.9 \mathrm{~V}$ vs. RHE & $\mathrm{CO}$ & [66] \\
\hline MoP@In-PC & $97 \%$ & $-43.8 \mathrm{~mA} / \mathrm{cm}^{2}$ at $-2.2 \mathrm{~V}$ vs. $\mathrm{Ag} / \mathrm{AgNO}_{3}$ & Formic acid & [69] \\
\hline
\end{tabular}

\subsection{FDH-Electrode Biohybrid}

Formate dehydrogenase (FDH) is the most efficient electrocatalyst for interconversion between $\mathrm{CO}_{2}$ and formate. There have been research interests in the enzyme activity under electrochemical conditions as adsorbed on an electrode surface, or as free in solution. 
FDHs are classified as two types of NADH-dependent and metal (Mo or W)-dependent enzymes ( $\mathrm{NADH}=$ nicotinamide adenine dinucleotide). The bio-electrochemical set-ups of NADH-dependent Candida boidinii ( $\mathrm{CbFDH}$ ) have been reported to show selective $\mathrm{CO}_{2}$ reduction to formate [74-79], where the regeneration efficiency of NADH was critical to improving the catalytic system.

Metal-dependent FDH has been studied as attached to an electrode surface. Hirst and coworkers showed reversible interconversion between $\mathrm{CO}_{2}$ and formate by Escherichia coli $\mathrm{FDH}(E c \mathrm{FDH})$ as adsorbed on a graphite-epoxy electrode [80]. The reversible redox current for the $\mathrm{CO}_{2}$ /formate conversion was observed during the cyclic voltammetry scans, and the formate oxidation became favored at higher $\mathrm{pH}$ within 6-8 range. Controlled potential electrolysis at $-0.6 \mathrm{~V}$ vs. SHE produced only formate product with $101.7 \pm 2.0 \% \mathrm{FE}$.

Redox-active polymer could enhance electron transfer between FDH and electrode. Milton and coworkers used cobaltocene-functionalized polyallylamine (Cc-PAA) to promote electron transfer between $E c F D H$ and glassy carbon electrodes [81]. The electroenzymatic $\mathrm{CO}_{2}$ reduction was detected at $-0.66 \mathrm{~V}$ vs. SHE close to the $\mathrm{Cc} / \mathrm{Cc}^{+}$redox couple of $-0.576 \mathrm{~V}$ vs. SHE. Bulk electrolysis at $-0.66 \mathrm{~V}$ vs. SHE using $50 \mathrm{mM} \mathrm{NaHCO}$ as the $\mathrm{CO}_{2}$ source provided formate production with FE $99 \pm 5 \%$, but the FE dropped to $65 \%$ after continuous electrolysis for $12 \mathrm{~h}$.

Bio-hybrid system gives a synthetic vision to develop electrocatalysts with high selectivity and efficiency, although low current density and limited catalytic sites remain as limitations for scale-up. In addition, a hybrid of molecular catalysts with electrode surface would be an alternative method to obtain well-performing catalysts. Ligand design and synthesis are other difficulties, but the conjugation of coordination complexes by electrode surface can provide chances to modify surface reactivity and efficiency of electrocatalysts.

\section{Nitrogen Fixation}

Nitrogen is an essential element in the metabolism of living organisms and one of the major elements that make up the body. The only way to take atmospheric $\mathrm{N}_{2}$ into organisms is via the nitrogen fixation process $[82,83]$. In a symbiotic relation, plants feed nitrogen-fixing bacteria with sugars as a reducing equivalent to perform the reduction of $\mathrm{N}_{2}$ to $\mathrm{NH}_{3}$, which is in return absorbed by plants. Although nature performs the process very efficiently, the direct $\mathrm{N}_{2}$ reduction has been one of the challenges in the research area of synthetic catalysts [84]. The industrial Haber-Bosch process takes charge of global ammonia production, but this process occupies $1 \%$ of annual fossil fuel consumption and $3 \%$ of annual $\mathrm{CO}_{2}$ emission because of the production conditions demanding high pressure and high temperature $[85,86]$. Mild reaction conditions are highly craved to decrease the consumption of the limited energy resources as well as anthropogenic $\mathrm{CO}_{2}$ emission $[87,88]$. There exist many research efforts to elucidate the mechanism of the natural catalytic system, nitrogenase, by investigating the structural features and synthetic model complexes [89-91]. In addition, heterogeneous catalysts were developed for nitrogen reductions, and bio-hybrid catalysts were studied in a way of attaching nitrogenase to an electrode surface.

\subsection{Nitrogenase}

In the 1960s, X-ray structure of the FeMo-nitrogenase active site was obtained, and thereafter the structural features and the relation with the enzyme reactivity have been studied to elucidate the nitrogen reduction process [92-94]. The $\mathrm{N}_{2}$ reduction is a series of electrochemical reactions requiring overall $6 \mathrm{e}^{-} / 6 \mathrm{H}^{+}$input. The FeMo-cofactor facilitates the nitrogen reaction, and the co-existing $\mathrm{P}$ cluster is in charge of the electron-transfer steps. The FeMo cluster is buried under the enzyme protein to selectively promote the multi-electron reduction process (Figure 3).

$$
\mathrm{N}_{2}+8 \mathrm{H}^{+}+16 \mathrm{MgATP}+8 \mathrm{e}^{-} \rightarrow 2 \mathrm{NH}_{3}+\mathrm{H}_{2}+16 \mathrm{MgADP}+16 \mathrm{Pi}
$$




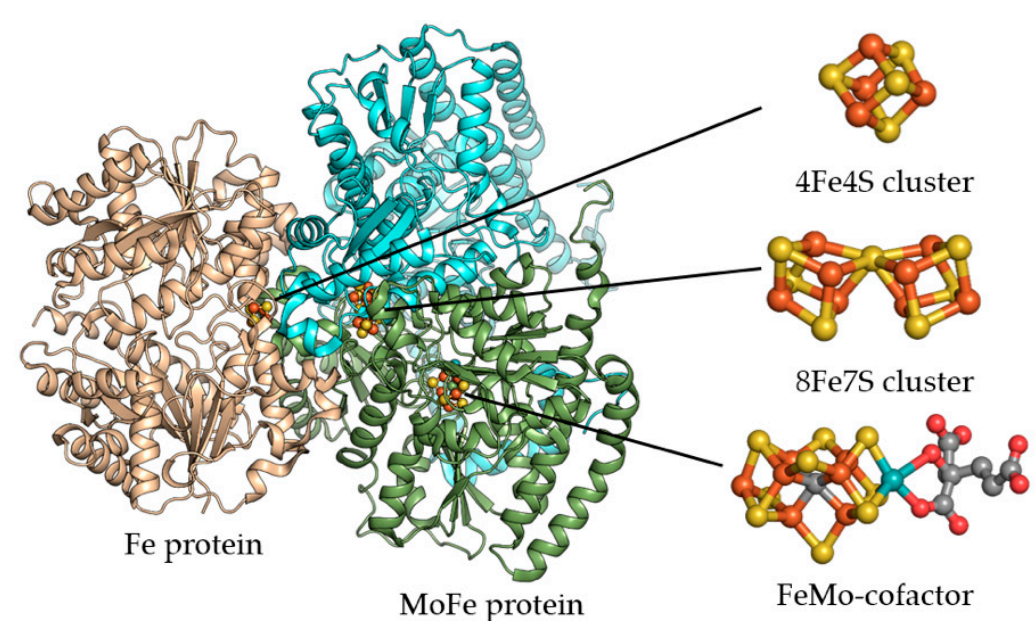

Figure 3. Structure of molybdenum nitrogenase, $4 \mathrm{Fe} 4 \mathrm{~S}$ cluster, $8 \mathrm{Fe} 7 \mathrm{~S}$ cluster, FeMo-cofactor, PDB code 2 AFK.

The FeMo-cofactor has a double-cubane type of $\mathrm{Mo}_{7} \mathrm{Fe}_{7} \mathrm{~S}$ cluster, where each cubane is bonded by a carbide $\left(\mathrm{C}^{4-}\right)$ center and a Mo atom is positioned at an end of the cluster [95-97]. Although the reaction mechanism remains obscure in the research of $\mathrm{N}_{2}$ reduction catalysts, both the Fe and Mo sites have been considered as the active sites for the nitrogen reactions. In the current review, we focus on the Mo-based model complexes.

\subsection{Structural Analogs of Nitrogenase}

In 1978, Holm and coworkers synthesized $\left[\mathrm{Mo}_{2} \mathrm{Fe}_{6} \mathrm{~S}_{8}\right]$ (22) cluster as a model of the FeMo-nitrogenase through a self-assembly method [98,99]. Later, in 1982, the same group reported a cubane-type structure of $\left[\mathrm{MoFe}_{3} \mathrm{~S}_{4}\right](23)$ by removing a Mo ion from $\left[\mathrm{Mo}_{2} \mathrm{Fe}_{6} \mathrm{~S}_{8}\right],[100,101]$ which showed very similar EXAFS data as the original FeMocofactor [102]. In 1993, Coucouvanis and coworkers synthesized a citrate-stabilized $\left[\mathrm{MoFe}_{3} \mathrm{~S}_{4}\right](24)$, similar to the homocitrate-coordinated FeMo-nitrogenase [103]. In addition, $\left[(\mathrm{Tp}) \mathrm{MoFe}_{3} \mathrm{~S}_{4} \mathrm{Cl}_{3}\right]^{1-}$ (25) cluster was synthesized using hydrotrispyrazolylborate(Tp) ligand as a model of homocitrate [104]. Along with the structural modeling of the FeMo-cofactor, Mo-based complexes were studied for the catalytic $\mathrm{N}_{2}$ reduction [105-107] (Scheme 12).

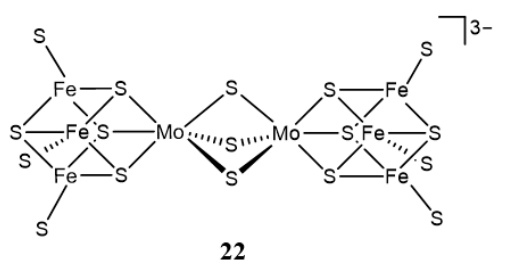

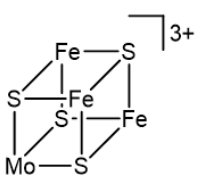

23
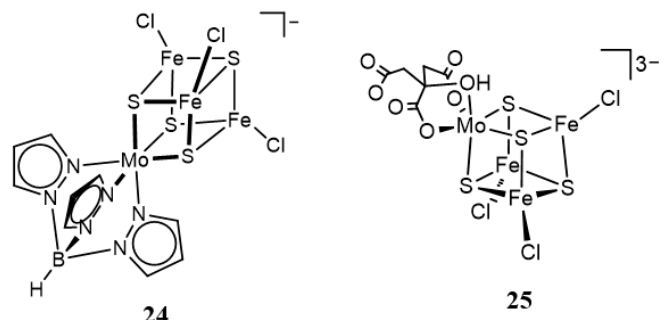

Scheme 12. Nitrogenase model complexes.

\subsection{Synthetic Electrocatalysts for $\mathrm{N}_{2}$ Reduction}

\subsubsection{Homogeneous Mo Complexes for $\mathrm{N}_{2}$ Reduction}

In 1988, Hidai reported examples of converting $\mathrm{N}_{2}$ to silylamines using zero-valent Mo coordinated by phosphine ligands, cis- $\mathrm{Mo}\left(\mathrm{N}_{2}\right)_{2}\left(\mathrm{PMe}_{2} \mathrm{Ph}\right)_{4}(\mathbf{2 6})$ and $\mathrm{Mo}\left(\mathrm{N}_{2}\right)_{2}(\mathrm{dpe})_{2}(27)$ (Scheme 13) [108]. Complex 26 produced $23.7 \% \mathrm{~N}\left(\mathrm{SiMe}_{3}\right)_{3}$ under optimized conditions of $\mathrm{N}_{2}$ using $\mathrm{Me}_{3} \mathrm{SiCl}$ and $\mathrm{Na}$ (or Li) as reductant, whereas complex 27 showed less activity of $9.7 \%$ conversion yield under the same condition. The monodentate phosphine made a more active Mo site than the bidentate phosphine. Even though the conversion yield was low, it gave early examples of Mo-phosphine catalysts for $\mathrm{N}_{2}$ conversion reactions. 


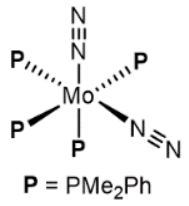

26

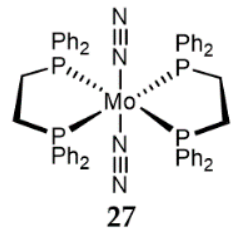

27

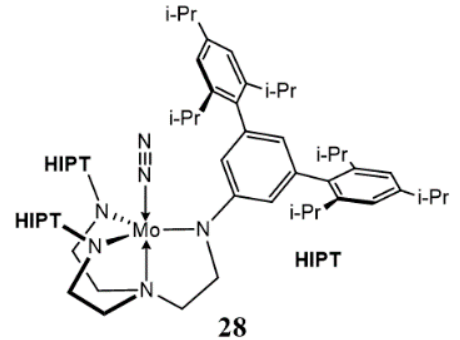

30a, $\mathbf{R}=\mathrm{H}$

$30 \mathrm{~b}, \mathrm{R}=\mathrm{Ph}$

30c, $\mathrm{R}=\mathrm{OMe}$

$30 \mathrm{~d}, \mathrm{R}=\mathrm{Fc}$

$30 \mathrm{e}, \mathbf{R}=\mathrm{Rh}$

30f, $\mathbf{R}=\mathrm{Et}^{\mathrm{Fc}}$

30g, $\mathbf{R}=\mathrm{Ph}^{\mathrm{Fc}}$

29

Scheme 13. Homogeneous Mo complexes.

In 2003, Yandulov and Schrock used a high-valent Mo(III-IV) ion stabilized by a tetradentate triamidoamine ligand for the reduction of $\mathrm{N}_{2}$ to $\mathrm{NH}_{3}$ [109]. The coordination of a hexaisopropylterphenyltriamido amine (HIPT) ligand to Mo(IV) ion gave $\left[\mathrm{HIPTN}_{3} \mathrm{~N}\right] \mathrm{MoCl}$, where the six hexaisopropylterphenyl groups sterically enclosed the Mo active site [110]. The bulky ligand system prevented dimerization of the complex by conserving the single Mo center $[106,111]$. Unlike the FeMo-cofactor, the Mo complex was coordinated by organic $\mathrm{N}$ donors, but the reactivity study of $\left[\mathrm{HIPTN}_{3} \mathrm{~N}\right] \mathrm{Mo}^{\mathrm{III}}\left(\mathrm{N}_{2}\right)(28)$ species provided implemental results to understand an $\mathrm{N}_{2}$ reduction process (Scheme 13). Using a proton source of $[(2,6-$ lutidinium $)(\mathrm{BArF})]$ and decamethyl chromocene as a reductant, complex 28 generated 7.56 equiv. of $\mathrm{NH}_{3}$ per a Mo ion and $63 \%$ yield per a reductant, which was comparable to that of FeMo-nitrogenase $\left(75 \% \mathrm{NH}_{3}, 25 \% \mathrm{H}_{2}\right)$ [112]. They proposed an $\mathrm{N}_{2}$ reduction mechanism catalyzed by a single Mo site based on spectral data and X-ray crystal structures of intermediates. X-ray crystal structures and spectral data characterized the nitrogen reaction intermediates such as $\mathrm{Mo}\left(\mathrm{N}_{2}\right), \mathrm{Mo}-\mathrm{N}=\mathrm{NH},[\mathrm{Mo}=\mathrm{N}-$ $\left.\mathrm{NH}_{2}\right]^{+}, \mathrm{Mo} \equiv \mathrm{N},\left[\mathrm{Mo}=\mathrm{N}-\mathrm{NH}_{3}\right]^{+},[\mathrm{Mo}=\mathrm{NH}]^{+},\left[\mathrm{Mo}-\mathrm{NH}_{3}\right]^{+}$, and $\mathrm{MoNH}_{3}$, which suggested the $\mathrm{N}_{2}$ reduction pathway including $6 \mathrm{e}^{-} / 6 \mathrm{H}^{+}$processes [113-117]. In the proposed pathway, protons bind to one nitrogen to release the first $\mathrm{NH}_{3}$, and the next protonation occurs on the remaining nitrogen to produce the second $\mathrm{NH}_{3}$ (Scheme 14). Their studies gave a research basis for a Mo-based $\mathrm{N}_{2}$ reduction process [118].

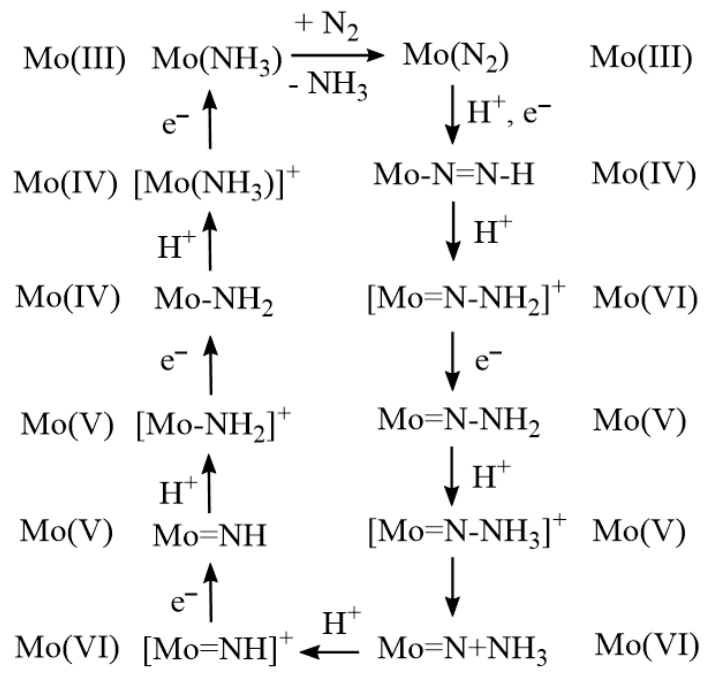

Scheme 14. $\mathrm{N}_{2}$ reduction pathways by Schrock complex. 
In 2011, Nishibayashi and coworkers tried to improve the $\mathrm{N}_{2}$ reduction activity of Mo complexes by utilizing redox-active ligands. They modified the Hidai complex (26) with ferrocenyl diphosphine ligand to prepare trans-Mo( $\left(\mathrm{N}_{2}\right)_{2}(\mathrm{depf})_{2}$ (29) (depf $=$ diethylphosphinoferrocene) [119]. Complex 29 performed the silylamine production under $1 \mathrm{~atm}$ of $\mathrm{N}_{2}$ at room temperature using $\mathrm{Na}$ and $\mathrm{Me}_{3} \mathrm{SiCl} . \mathrm{Me}_{3} \mathrm{SiCl}$ formed $\mathrm{Me}_{3} \mathrm{Si}$ - radical in the presence of $\mathrm{Na}$ reductant, and a $\mathrm{Me}_{3} \mathrm{Si}$. radical derived the $\mathrm{N}_{2}$ reaction to produce $\mathrm{N}\left(\mathrm{SiMe}_{3}\right)_{3}$ (226 equiv. per a Mo atom for $200 \mathrm{~h}$ ). Acid post-treatment of the produced silylamine afforded $\mathrm{NH}_{3}$. The same group used other redox-active PNP type ligands for Mo catalysts [120]. Reduction of the $\left[\mathrm{MoCl}_{3}(\mathrm{PNP})\right]$ species with $\mathrm{Na} / \mathrm{Hg}$ under $\mathrm{N}_{2}$ formed an $\mathrm{N}_{2}$-bridged di-Mo complex $\left[\mathrm{Mo}\left(\mathrm{N}_{2}\right)_{2}(\mathrm{PNP})\right]_{2}\left(\mu-\mathrm{N}_{2}\right)$ (30a-c) (Scheme 13). Subsequent reaction with 4 equiv. of $\mathrm{HBF}_{4} \cdot \mathrm{OEt}_{2}$ and pyridine generated a Mo-hydrazide species, and further reaction with [LutH] OTf produced $\mathrm{NH}_{3}$ (23.2 equiv. of $\mathrm{NH}_{3}$ per a catalyst). The reaction mechanism was explained similarly as proposed by Schrock, where one nitrogen site receives $3 \mathrm{e}^{-} / 3 \mathrm{H}^{+}$to release $\mathrm{NH}_{3}$ and subsequent $3 \mathrm{e}^{-} / 3 \mathrm{H}^{+}$reaction of the remaining $\mathrm{Mo}(\mathrm{N})$ generates (Scheme 15). In the screening of reductants of $\mathrm{Cr}-\mathrm{Cp}$ $\left(\mathrm{E}_{1 / 2}=-0.88 \mathrm{~V}\right.$ vs. $\mathrm{Ag} / \mathrm{Ag}^{+}$in MeCN$), \mathrm{Co}-\mathrm{Cp}\left(\mathrm{E}_{1 / 2}=-1.15 \mathrm{~V}\right), \mathrm{Cr}-\mathrm{Cp}^{*}\left(\mathrm{E}_{1 / 2}=-1.35 \mathrm{~V}\right)$ and proton sources such as [LuTH]OTf (pKa 14.4 in MeCN), pyridinium trifluoromethanesulfonate (pKa 12.6), and HOTF (pKa 2.6), the Nishibayashi complex exhibited the $\mathrm{N}_{2}$ reduction activity with $\mathrm{Co}-\mathrm{Cp}$ and $\mathrm{Cr}-\mathrm{Cp} \mathrm{p}^{*}$, but not with $\mathrm{Cr}-\mathrm{Cp}$ [121]. The complex showed the best performance with the combinatory use of Co-Cp and [LuTH]OTf.

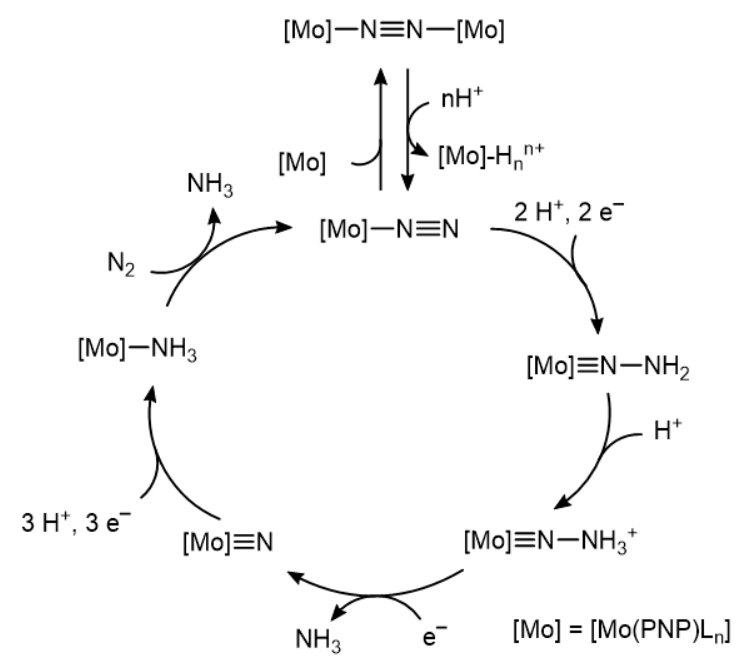

Scheme 15. $\mathrm{N}_{2}$ reduction pathway by Nishibayashi complex.

The electronic property of the pyridine ligand affected the catalytic reaction rate by modulating Mo-N $\equiv \mathrm{N}-\mathrm{Mo}$ bond strength [122]. In comparison with the $\mathrm{v}(\mathrm{NN})$ frequency $\left(1944 \mathrm{~cm}^{-1}\right)$ of unmodified pyridine (30a), the para-substitution with a phenyl group increased the frequency to $1950 \mathrm{~cm}^{-1}(30 \mathbf{b})$, whereas the methoxy group decreased to $1932 \mathrm{~cm}^{-1}$ (30c). The relative bond strength was reflected in the $\mathrm{N}_{2}$ reduction reactivity of catalysts. Complex 30a provided 21-23 equiv. of $\mathrm{NH}_{3}$ production, but 30c with the electrondonating methoxy substituent induced the highly efficient $\mathrm{NH}_{3}$ formation (34 equiv. per catalyst) by accelerating the protonation step. Similar to the P cluster of the nitrogenase, the substitution of a redox-active ferrocene assisted the catalytic reaction $(30 \mathrm{~d}-\mathrm{g})$ [123]. Ferrocene-attached Mo complexes showed a similar $v(\mathrm{NN})$ stretching frequency as the complex 30a but increased the $\mathrm{NH}_{3}$ production to 37 equiv. per catalyst. Although unmodified ferrocene did not affect the $\mathrm{NN}$ bond strength, modification of the ferrocene with ethyl or phenyl groups caused the slight shift of the $v(\mathrm{NN})$ value indicating electronic connectivity through the chemical bonds. The $v(\mathrm{NN})$ value was measured as $1939 \mathrm{~cm}^{-1}$ with the ethyl-ferrocene and $1951 \mathrm{~cm}^{-1}$ with the phenyl-ferrocene. Consistent with the 
electron-donating effect, the ethyl-ferrocene resulted in 30 equiv. of $\mathrm{NH}_{3}$ formation per catalyst, which was higher than 10 equiv. of $\mathrm{NH}_{3}$ of the phenyl-ferrocene.

The Nishibayashi type PNP-Mo catalysts began the $\mathrm{N}_{2}$ reduction in the $\mathrm{N}_{2}$-bound Mo state after a halide abstraction step. They recently reported the presence of iodide ligand rather improved the catalytic activity because of the electron-withdrawing property. PNP-MoI ${ }_{3}$ complexes (31a-d) were synthesized with phosphine ligands varied by different substituents such as isopropyl, tert-butyl, adamantyl, and phenyl groups (Scheme 16) [124]. The $\mathrm{P}(\text { tert-butyl })_{2}$ group gave the highest $\mathrm{NH}_{3}$ production. The catalytic activity was further examined by changing the para-position of pyridine with $\mathrm{MeO}, \mathrm{Me}, \mathrm{Ph}, \mathrm{Fc}$, and Rc (32a-e) with keeping the $\mathrm{P}$ (tert-butyl $)_{2}$ moiety of PNP ligand. At the time, the para-Ph substituent showed the highest activity of 90 equiv. of $\mathrm{NH}_{3}$ production, which was much higher than the case of para-MeO substituent [125]. The trend was opposite from the case of $\mathrm{N}_{2}$-bridged dinuclear Mo complexes. Complex 31b exhibited a maximum 415 equiv. of $\mathrm{NH}_{3}$ production per catalyst, which was 35 times higher activity than the $\mathrm{N}_{2}$-bridged $\mathrm{Mo}_{2}$ complex. Furthermore, they examined the effect of PCP-type carbene ligands of 1,3-bis((di-tert-butylphosphino)methyl)benzimidazol-2-ylidene (PCP-1), 1,3-bis(2-(di-tertbutylphosphino)ethyl)imidazol-2-ylidene (PCP-2) [126] (Scheme 16). The PCP-1-Mo (33) produced 100 equiv. of $\mathrm{NH}_{3}$ per catalyst, but the PCP-2-Mo (34) showed a low reactivity of 1.6 equiv. of $\mathrm{NH}_{3}$ per catalyst. The identity of the reducing agent and proton source also affected the nitrogen reduction activity of Mo catalysts. Complex 33 showed the high activity when used together with $\mathrm{SmI}_{2}$ and $\mathrm{H}_{2} \mathrm{O}$ (or ethylene glycol) instead of CoCp* and [LutH]OTf. The combinatory use of $\mathrm{SmI}_{2}$ and ethylene glycol resulted in turnover frequency (TOF) of $7000 \mathrm{~h}^{-1}$ for the $\mathrm{NH}_{3}$ generation, and the condition using $\mathrm{H}_{2} \mathrm{O}$ as a proton source slightly decreased TOF to $6800 \mathrm{~h}^{-1}$ [127]. Using ethylene glycol as a proton source produced $22 \%$ (relative to a reductant) of $\mathrm{H}_{2}$ as a side product, but $\mathrm{H}_{2} \mathrm{O}$ reduced the ratio to $\sim 2 \%$. The optimized condition using $\mathrm{H}_{2} \mathrm{O}$ and $\mathrm{SmI}_{2}$ increased the $\mathrm{NH}_{3}$ productivity of complex 33 to 4350 equiv. per catalyst and TOF to $112.9 \mathrm{~min}^{-1}$, which was close to the nitrogenase activity of $40-120 \mathrm{~min}^{-1}$ [128].
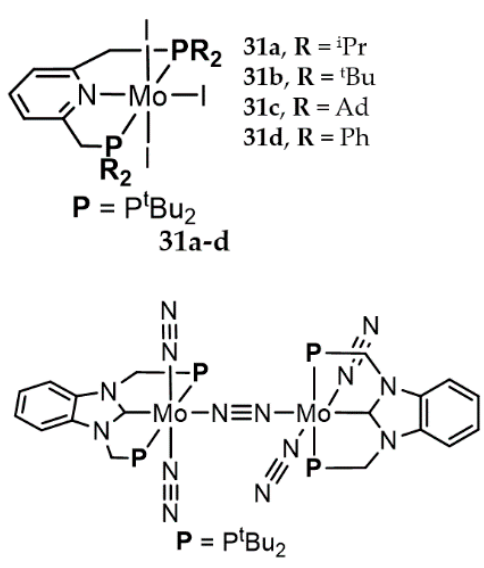

33
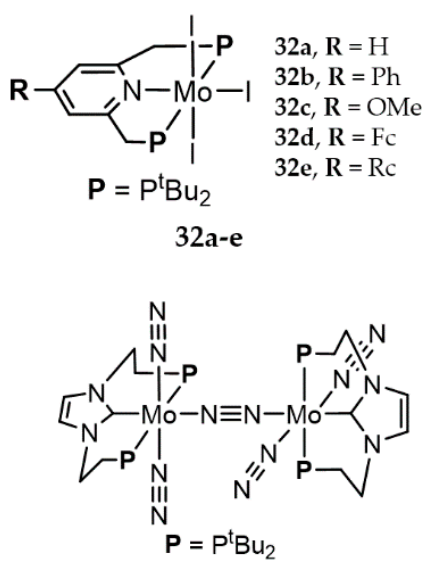

34

Scheme 16. Homogeneous PNP-Mo complexes.

\subsubsection{Heterogeneous Mo-Containing $\mathrm{N}_{2}$-Reduction Electrocatalysts}

Nitrogen reduction catalysts should deliver protons selectively to a bound nitrogen on their active sites, because the thermodynamic potential of a competitive proton reduction is relatively low. For this, the intrinsic property of an active metal center is an important factor to determine the $\mathrm{N}_{2}$ reduction reactivity of catalysts. Novel transition metals have shown nitrogen reactivities, but their limited reserves and high-cost issues are obstacles for their industrial scale-up as catalysts [129-135]. Earth-abundant metals are promising alternatives for nitrogen catalysts. Mo ions as the forms of $\mathrm{MoS}_{2}, \mathrm{MoO}_{3}, \mathrm{MoN}, \mathrm{Mo}_{2} \mathrm{~N}$, and $\mathrm{Mo}_{2} \mathrm{C}$ were proven to be active for the $\mathrm{N}_{2}$ reduction. The specific affinity of Mo ion to nitrogen has been 
reported in the previous experiments [136,137]. In addition, the utilization of mixed metal elements could increase $\mathrm{N}_{2}$ reactivity and promote electron-transfer by tuning surface energy states.

The $\mathrm{N}_{2}$ reactivity seems to be varied by Mo crystal orientation. Wang and coworkers reported that $\mathrm{Mo}(110)$ plane has higher reactivity with $\mathrm{N}_{2}$ than other planes of (200) and (211) [138]. They prepared four types of Mo electrodes of Mo-foil, Mo-A-R, Mo-D-R-1h, and Mo-D-R-5h through electrodeposition, and Mo-D-R-5h showed the highest (110) orientation ratio based on XRD patterns [139-141].

Outermost Mo is an active site, but the reactivity and mechanism are determined by supporting elements. Sun and coworkers studied different reactivities of Mo, conjugated by $\mathrm{O}, \mathrm{S}$, and $\mathrm{N}$ atoms, by comparing $\mathrm{MoO}_{3}, \mathrm{MoS}_{2}$, and $\mathrm{MoN}$ [142-144]. Edge sites of Mo chalcogenides are known to be active for $\mathrm{N}_{2}$ reaction. MoN surface has shown $\sim 0.2$ lower overpotential than Mo chalcogenides. It is possibly understood that as a surface Mo- $\mathrm{N}$ is reduced to $\mathrm{NH}_{3}$, an empty Mo site facilitates subsequent $\mathrm{N}_{2}$ adsorption and reduction process.

Conductive support was also an important component to improve the electrocatalytic performance of $\mathrm{MoS}_{2}$, because the large conductive surface area supports more $\mathrm{MoS}_{2}$ active area as well as increases surficial electrical conductivity. Tian and coworkers achieved significant improvement of $\mathrm{FE}$ ( $10.94 \%$ at $-0.3 \mathrm{~V}$ vs. RHE) of $\mathrm{MoS}_{2}$ using $\mathrm{Ti}_{3} \mathrm{C}_{2}$ MXene [145]. The catalytic efficiencies and reaction rates of the Mo-based electrocatalysts are compared in Table 2.

Table 2. Faradaic efficiencies, $\mathrm{NH}_{3}$ formation rates of different Mo-based catalysts.

\begin{tabular}{ccccc}
\hline Catalyst & FE & NH $_{3}$ Formation Rate & Ref. \\
\hline (110)-oriented Mo nanofilm & $0.72 \%$ & $3.09 \times 10^{-11} \mathrm{mols}^{-1} \mathrm{~cm}^{-2}$ at $-0.49 \mathrm{~V}$ vs. RHE & [138] \\
\hline $\mathrm{MoO}_{3}$ nanosheets & $1.9 \%$ & $4.80 \times 10^{-10} \mathrm{mols}^{-1} \mathrm{~cm}^{-2}$ at $-0.5 \mathrm{~V}$ vs. RHE & [142] \\
\hline MoN nanosheets & $1.15 \%$ & $3.01 \times 10^{-10} \mathrm{mols}^{-1} \mathrm{~cm}^{-2}$ at $-0.3 \mathrm{~V}$ vs. RHE & {$[143]$} & {$[144]$} \\
\hline $\mathrm{MoS}_{2}$ & $1.17 \%$ & $8.08 \times 10^{-11} \mathrm{mols}^{-1} \mathrm{~cm}^{-2}$ at $-0.5 \mathrm{~V}$ vs. RHE & [145] \\
\hline $1 \mathrm{~T}-\mathrm{MoS}_{2} @ \mathrm{Ti}_{3} \mathrm{C}_{2}$ & $10.94 \%$ & $30.33 \mu \mathrm{g} \mathrm{h}^{-1} \mathrm{mg}^{-1}$ cat. at $-0.3 \mathrm{~V}$ vs. RHE &
\end{tabular}

\subsection{Nitrogenase-Electrode Biohybrid}

In general, synthetic modeling studies focus on enzyme active sites, but protein structure should be an important factor to control the enzyme reaction. Even a small mutation of a nearby amino acid could distort the entire enzyme reactivity. For example, the substitution of a nearby $\beta-98^{\mathrm{Tyr}}$ amino acid to $\beta-98^{\mathrm{His}}$ deactivated the $\mathrm{N}_{2}$ reduction ability of the mutated FeMo-nitrogenase [146]. However, a reduction of hydrazine $\left(\mathrm{N}_{2} \mathrm{H}_{2}\right)$ to $\mathrm{NH}_{3}$ still occurred in the mutated FeMo-nitrogenase. Interestingly, the mutation by $\beta-98^{\mathrm{His}}$ improved electron-accepting ability from an un-natural reducing agent to promote reductions of azide $\left(\mathrm{N}_{3}{ }^{-}\right)$or nitrite $\left(\mathrm{NO}_{2}{ }^{-}\right)$to $\mathrm{NH}_{3}$ [147]. Using electron mediators such as polyaminocarboxylate-ligated Eu [126] and polyallylamine (PAA) polymer-CoCp 2 [148] further improved reduction efficiencies. Rather in the presence of Fe-protein, without using an additional electron mediator, electron transfer between Fe-protein and FeMocluster became slow. Badalyan and coworkers showed experimentally that electron transfer between FeMo-cluster and Fe protein is the rate-determining step by calculating reaction rate constants using cyclic voltammetry data [149].

King and coworkers made a biohybrid system by attaching FeMo-nitrogenase to CdS nanorods for applications to a photocatalytic reduction of $\mathrm{N}_{2}$ to $\mathrm{NH}_{3}$ [128]. In the biological reaction, electron transfer steps from the $\mathrm{P}$ cluster to the FeMo-cluster require 16ATP $\left(\mathrm{E}_{\mathrm{m}}=-0.42 \mathrm{~V}\right)(\mathrm{ATP}=$ adenosine triphosphate). In the bio-hybrid system, irradiation of CdS nanorod with $405 \mathrm{~nm}$ wavelength generated excited electrons with $-0.8 \mathrm{eV}$, which was transferred to the FeMo-nitrogenase to proceed with the $\mathrm{N}_{2}$ reduction reaction. The TOF was $75 \mathrm{~min}^{-1}$ and the $\mathrm{NH}_{3}$ production rate was $315 \pm 55 \mathrm{nmol}\left(\mathrm{mg} \mathrm{MoFe}\right.$ protein $\left.{ }^{-1}\right) \mathrm{min}^{-1}$, 
which was $63 \%$ less activity compared to the enzyme activity with the presence of Fe protein and ATP. Upon using nitrogenase inhibitors such as acetylene, $\mathrm{CO}$, and $\mathrm{H}_{2}$ [150-152], the enzyme activity became silent excluding a possible $\mathrm{N}_{2}$ reduction by CdS only.

Biohybrid of FeMo-nitrogenase with electrode enabled the enzyme to function in the absence of ATP, and thereby provided ways to study the enzyme reaction out of intracellular conditions. In future research, new biohybrid designs are required to decrease overpotential for the $\mathrm{N}_{2}$ reduction as well as to develop methodologies for the transformation of $\mathrm{N}_{2}$ to useful molecules.

\section{4. $\mathrm{H}_{2}$ Evolution}

The proton reduction is always a competitive reaction in the electrocatalytic reductions of $\mathrm{CO}_{2}$ and $\mathrm{N}_{2}$, because the $2 \mathrm{H}^{+} / \mathrm{H}_{2}$ reduction is thermodynamically favored. However, on the other hand, hydrogen molecules can be used as the simplest energy carrier for solar or electric energy conversion and storage [153]. Due to the importance, various transition metal-based electrocatalysts were developed for $\mathrm{H}_{2}$ evolution [154-156].

\subsection{Homogeneous Mo Complexes for $\mathrm{H}_{2}$ Evolution}

Nature does not use Mo metal for metabolic hydrogen reactions of $\mathrm{H}_{2}$ evolution and splitting, but hydrogenase active site inspired ligand design for Mo complexes. It was shown that anionic cyclopentadienyl (Cp) ligand has a similar electronic property as the Ni ligation sphere of the [NiFe]-hydrogenase active site [157]. Felton and Donovan reported that $\left[\left(\eta^{5}-\mathrm{C}_{5} \mathrm{H}_{5}\right) \mathrm{Mo}(\mathrm{CO})_{3}\right]_{2}$ (Scheme 17) (35) complex promoted the reduction of acetic acid in acetonitrile with $0.9 \mathrm{~V}$ overpotential [158]. Fan and Hu utilized polyhapto ligands to prepare Mo-carbonyl complexes of $\left(\eta^{3}-\mathrm{C}_{3} \mathrm{H}_{5}\right) \mathrm{Mo}(\mathrm{CO})_{2}\left(\mathrm{CH}_{3} \mathrm{CN}\right)_{2} \mathrm{Br}$ (36), $\left(\eta^{3}-\mathrm{C}_{3} \mathrm{H}_{5}\right) \mathrm{Mo}(\mathrm{CO})_{2}$ (dppe) $\mathrm{Br}(37),\left(\eta^{5}-\mathrm{C}_{5} \mathrm{H}_{5}\right) \mathrm{Mo}(\mathrm{CO})_{3} \mathrm{I}(38)$, and $\left(\eta^{5}-\mathrm{C}_{5} \mathrm{H}_{5}\right) \mathrm{Mo}(\mathrm{CO})_{2} \mathrm{PPh}_{3} \mathrm{I}$ (39) (Scheme 17) [159]. Complex 36-39 showed similar reactivities of the halide dissociation during the cyclic voltammetry in $\mathrm{MeCN}$ solution and also exhibited similar catalytic activity of $16-27 \mathrm{TON}$ for $5 \mathrm{~h}$ for the reduction of trifluoroacetic acid as requiring $\sim 1 \mathrm{~V}$ overpotentials.
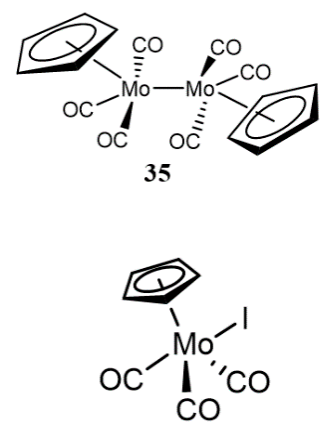

38
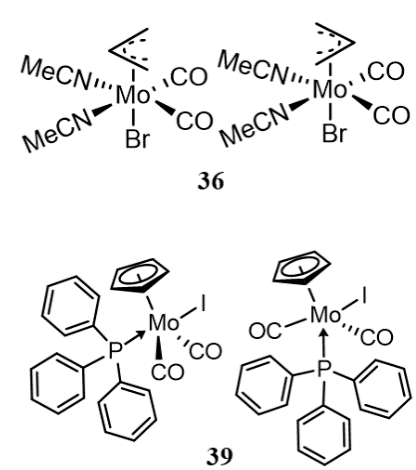
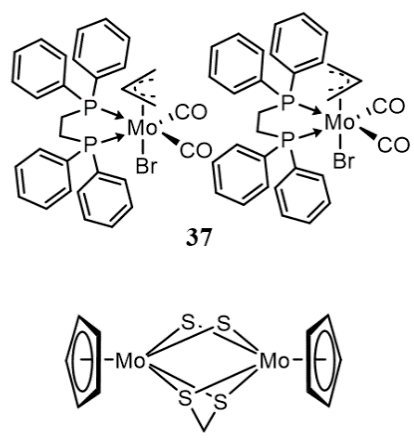

40

Scheme 17. Homogeneous Mo complexes for $\mathrm{H}_{2}$ evolution.

Hydrodesulfurization utilizes Mo-sulfides as a catalytic surface [160]. Similar to the $\mathrm{MoS}_{2}$ active site, Mo-sulfide moiety has been synthesized in the Mo coordination environment. DuBois and coworkers used $\mathrm{Cp}$ ligand to obtain a sulfide bridged dinuclear Mo complex, $\left[\left(\eta^{5}-\mathrm{C}_{5} \mathrm{H}_{5}\right) \mathrm{Mo}(\mu-\mathrm{S})\right]_{2}\left(\mu-\mathrm{S}_{2} \mathrm{CH}_{2}\right)$ (Scheme 17) (40). Complex 40 facilitated reduction of $p$-cyanoanilinium tetrafluoroborate at $-0.7 \mathrm{~V} v s . \mathrm{Fc}^{+} / \mathrm{Fc}$ in $\mathrm{MeCN}$ solution containing $0.3 \mathrm{M}$ of $\mathrm{Et}_{4} \mathrm{NBF}_{4}$ electrolyte [161]. Controlled-potential electrolysis at $-0.96 \mathrm{~V}$ vs. $\mathrm{Fc}^{+} / \mathrm{Fc}$ generated $10.6 \mathrm{~mol}$ of $\mathrm{H}_{2}$ gas per catalyst with $98 \pm 5 \% \mathrm{FE}$. The catalytic activity was compared using different proton sources such as triflic acid ( $\mathrm{pKa}=2.6$ in $\mathrm{MeCN}$ ), $p$-cyanoanilinium tetrafluoroborate (7.6) and $p$-cyanoanilinium tetrafluoroborate (9.6). Higher $\mathrm{pKa}$ of the proton source shifted the proton reduction potential to the negative 
direction. Kinetic studies suggested that the elimination of $\mathrm{H}_{2}$ from the catalytic site is the rate-determining step.

Chang and coworkers synthesized the $\operatorname{Mo}\left(\mathrm{S}_{2}\right)$ moiety in a pentadentate polypyridyl Mo complex $\left[\left(\kappa^{5}-\mathrm{PY}_{5} \mathrm{Me}_{2}\right) \mathrm{MoS}_{2}\right]^{2+}$ (42) (PY5Me $2=2,6$-bis(1,1-bis(2-pyridyl)ethyl)pyridine) from a reaction of $\left[\left(\kappa^{5}-\mathrm{PY} 5 \mathrm{Me}_{2}\right) \mathrm{Mo}\left(\left(\kappa^{1}-\mathrm{CF}_{3} \mathrm{SO}_{3}\right)\right]\left(\mathrm{CF}_{3} \mathrm{SO}_{3}\right)(41)\right.$ with $\mathrm{S}_{8}$ (Scheme 18) [162]. Complex 42 generated $\mathrm{H}_{2}$ in acetate buffer ( $\mathrm{pH}$ 3) at the onset potential of $-0.58 \mathrm{~V}$ vs. SHE. Controlled potential electrolysis at $-0.83 \mathrm{~V}$ overpotential produced $\mathrm{H}_{2}$ gas with $\sim 100 \% \mathrm{FE}$ and $280 \mathrm{~mol} / \mathrm{s}$ TOF. Albeit less active than 42, Complex 41 also showed catalytic activity to produce $\mathrm{H}_{2}$ gas in $0.6 \mathrm{M}$ phosphate buffer ( $\mathrm{pH}$ 7) requiring $0.52 \mathrm{~V}$ overpotential. Controlled potential electrolysis at $0.64 \mathrm{~V}$ overpotential produced $\mathrm{H}_{2}$ gas as $1600 \mathrm{~mol} / \mathrm{h}$ TOF per catalyst. Complex 41 also produced $\mathrm{H}_{2}$ gas in seawater at the onset potential of $-0.81 \mathrm{~V}$ vs. SHE with $1200 \mathrm{~mol} / \mathrm{h}$ TOF at $-1.40 \mathrm{~V}$ vs. SHE. [163].

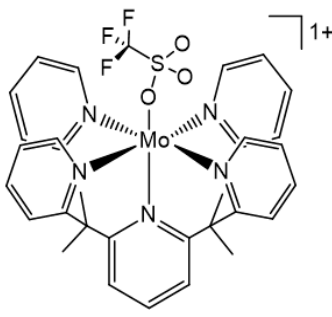

41

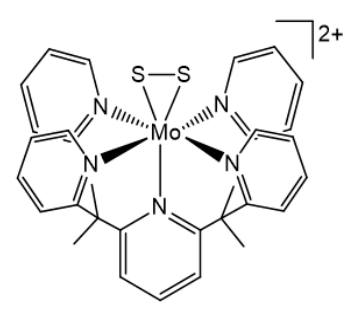

42

Scheme 18. Structure of homogeneous Mo complexes for $\mathrm{H}_{2}$ evolution.

Streb and coworkers observed that partial substitution of terminal disulfide in $\left[\mathrm{Mo}_{3} \mathrm{~S}_{13}\right]^{2-}$ by $\mathrm{H}_{2} \mathrm{O}$ to $\left[\mathrm{Mo}_{3} \mathrm{~S}_{7}\left(\mathrm{H}_{2} \mathrm{O}\right) \mathrm{x}\right]^{(2-\mathrm{x})-}$ increased the catalytic activity. Instead, the substitution of terminal disulfide with halides to $\left[\mathrm{Mo}_{3} \mathrm{~S}_{7 \times 6}\right]^{2-}(\mathrm{X}=\mathrm{Cl}, \mathrm{Br})$ decreased significantly the HER activity [164]. They suggested that, if terminal disulfide is protonated, energetically stable and catalytically inactive species are formed. It looks critical the formation of a vacant coordination site on a terminal Mo to generate catalytically active Mo- $\mathrm{H}$.

Eisenberg and coworkers used dithiolene ligands to obtain Mo-sulfides moiety in $\mathrm{MoL}_{2}(\mathrm{bdt})_{2}(43 \mathrm{a}-\mathrm{g})(\mathrm{bdt}=$ benzene-1,2-dithiol) (Scheme 19) [11]. Two-electron reduction of complexes 43a-e in $\mathrm{MeCN} / \mathrm{H}_{2} \mathrm{O}$ (9:1) solution dissociated isonitrile ligands to generate $\mathrm{Mo}(\mathrm{bdt})_{2}$, which was the active species for the catalytic HER. Complexes 43a-g also showed photochemical HER in $\mathrm{MeCN} / \mathrm{H}_{2} \mathrm{O}$ solution under the conditions of using $\left[\mathrm{Ru}(\mathrm{bpy})_{3}\right] \mathrm{Cl}_{2}$ as a photosensitizer, $0.2 \mathrm{M}$ ascorbic acid ( $\mathrm{pH} 4)$ as an electron donor. Complexes 43a gave the highest TON of 520 for $24 \mathrm{~h}$ than other complexes $(<475 \mathrm{TON})$.

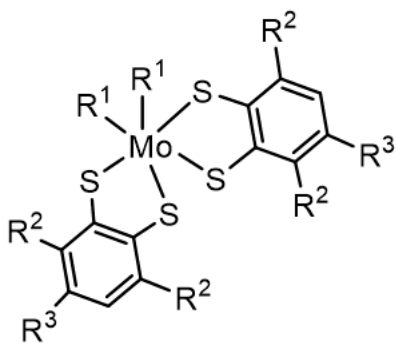

$$
\begin{aligned}
& \text { 43a, }\left(\mathrm{R}^{1}={ }^{\mathrm{t} B u N C}, \mathrm{R}^{2}=\mathrm{H}, \mathrm{R}^{3}=\mathrm{H}\right) \\
& \text { 43b, }\left(\mathrm{R}^{1}=\mathrm{t}^{\mathrm{t}} \mathrm{uNC}, \mathrm{R}^{2}=\mathrm{H}, \mathrm{R}^{3}=\mathrm{Me}\right) \\
& \text { 43c }\left(\mathrm{R}^{1}={ }^{\mathrm{t} B u N C}, \mathrm{R}^{2}=\mathrm{Cl}, \mathrm{R}^{3}=\mathrm{H}\right) \\
& \text { 43d }\left(\mathrm{R}^{1}=\mathrm{p}-\mathrm{MeOPhNC}, \mathrm{R}^{2}=\mathrm{H}, \mathrm{R}^{3}=\mathrm{H}\right) \\
& \text { 43e }\left(\mathrm{R}^{1}=\mathrm{BzNC}, \mathrm{R}^{2}=\mathrm{H}, \mathrm{R}^{3}=\mathrm{H}\right) \\
& \text { 43f }\left(2 \mathrm{R}^{1}=\text { dppe, } \mathrm{R}^{2}=\mathrm{H}, \mathrm{R}^{3}=\mathrm{H}\right) \\
& \text { 43g }\left(\mathrm{R}^{1}=\mathrm{MePh}_{2} \mathrm{P}, \mathrm{R}^{2}=\mathrm{H}, \mathrm{R}^{3}=\mathrm{H}\right)
\end{aligned}
$$

Scheme 19. Structure of homogeneous Mo complexes for $\mathrm{H}_{2}$ evolution.

Moly-oxo complexes have shown interesting proton reduction activities. Zhan and coworkers synthesized cis di-oxo Mo complex, $\left[\mathrm{Mo}^{\mathrm{VI}} \mathrm{L}(\mathrm{O})_{2}\right]$ (Scheme 20) (44) $(\mathrm{L}=2$ pyridylamino-N,N-bis(2-methylene-4-methoxy-6-tertbutylphenol)ion) [165]. Complex 44 promoted proton reduction at $0.25 \mathrm{M}$ phosphate buffer $(\mathrm{pH} 7)$ recording $360 \mathrm{~mol} / \mathrm{h}$ TOF (907 mV overpotential). Next, fluorine-substitution of $\left[\mathrm{MoL}^{\prime}(\mathrm{O})_{2}\right]$ (Scheme 20) (45) ( $\mathrm{L}^{\prime}=2$ pyridylamino-N,N-bis(2-methylene-4,6-difluorophenol)ion) gave higher TOF of $756 \mathrm{~mol} / \mathrm{h}$ 
(89\% $\mathrm{FE})$ at $-1.61 \mathrm{~V}$ vs. $\mathrm{Ag} / \mathrm{AgCl}$ in mixed acetonitrile/water (2:3) solution containing phosphate buffer (pH 6) [166].

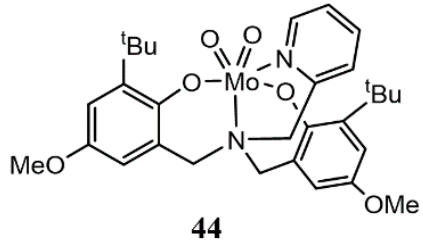

44

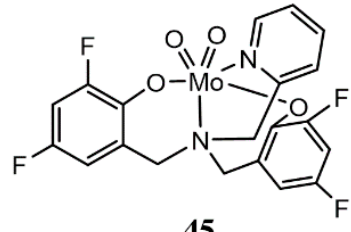

45

Scheme 20. Structure of homogeneous Mo complexes for $\mathrm{H}_{2}$ evolution.

Kim and coworkers reported the proton reactivity of $\left[\mathrm{MoO}\left(\mathrm{S}_{2} \mathrm{C}_{2} \mathrm{Ph}_{2}\right)_{2}\right]^{2-}(46)$ in $\mathrm{MeCN}$ solution. Treatment of protons ( $p$-toluenesulfonic acid) with complex 46 in MeCN processed dehydration of the complex to give $\left[\mathrm{Mo}(\mathrm{MeCN})_{2}\left(\mathrm{~S}_{2} \mathrm{C}_{2} \mathrm{Ph}_{2}\right)_{2}\right]$ (47) (Scheme 21) [167]. Complex 47 had poor solubility in polar solvents, and the fast dehydration of 46 prevented the use as an electrocatalyst. However, modification of the dithiolene ligand could make Mo ion function as HER electrocatalyst. Fontecave and coworkers utilized quinoxaline-pyran-fused dithiolene (qpdt ${ }^{2-}$ ), analogous to the molybdopterin (MPT), to prepare $\left(\mathrm{Bu}_{4} \mathrm{~N}\right)_{2}\left[\mathrm{MoO}(\mathrm{qpdt})_{2}\right]$ (48) (Scheme 22) [168]. The qpdt ${ }^{2-}$ ligand assisted the Mo-oxo site to catalyze HER. Electrocatalytic proton reduction of trifluoroacetic acid was detected at $-0.55 \mathrm{~V}$ vs. $\mathrm{Ag} / \mathrm{AgCl}$, and TOF of $1030 \mathrm{~s}^{-1}$ was obtained at $-1.3 \mathrm{~V}$ vs. $\mathrm{Ag} / \mathrm{AgCl}$ (FE $86 \%$ for $3 \mathrm{~h}$ ). Complex 48 also facilitated photocatalytic HER with $\left[\mathrm{Ru}(\mathrm{bpy})_{3}\right]^{2+}$ in $0.1 \mathrm{M}$ ascorbic acid ( $\mathrm{pH} 4)$ as recording TON 500 for $15 \mathrm{~h}$.

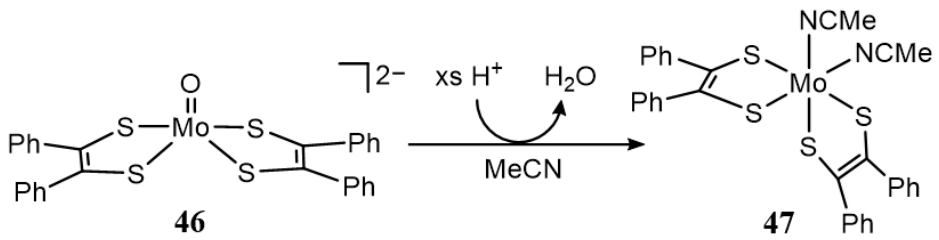

Scheme 21. Structure of homogeneous Mo complexes for $\mathrm{H}_{2}$ evolution.

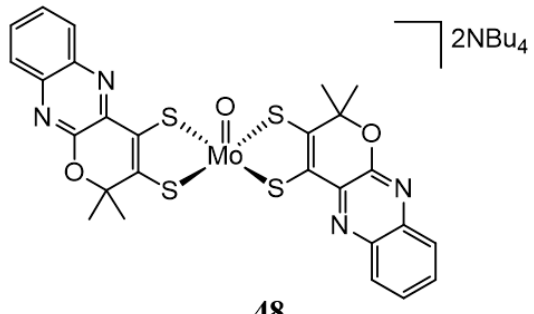

Scheme 22. Structure of homogeneous Mo complexes for $\mathrm{H}_{2}$ evolution.

\subsection{Heterogeneous Mo-Containing $\mathrm{H}_{2}$-Evolution Electrocatalyst}

In 2005, Norskov and coworkers calculated the free energy of atomic hydrogen bonding $\left(\Delta \mathrm{G}_{\mathrm{H}}^{\circ}\right)$ to $\mathrm{MoS}_{2}$ surface and compared it with other catalysts such as enzymes (FeMo cofactor and NiFe hydrogenase) and metal surfaces of $\mathrm{Au}, \mathrm{Pt}, \mathrm{Ni}$, and Mo [169]. Density functional theory (DFT) calculation results suggest that $\mathrm{Ni}$ and Mo bind strongly to atomic hydrogen; however, since the next proton/electron transfer steps are thermodynamically uphill, the $\mathrm{H}_{2}$-releasing step becomes slow as making those metals not suitable for HER. Interestingly, the metalloenzymes of FeMo-nitrogenase and NiFe-hydrogenase using $\mathrm{Ni}$ and Mo elements had similar hydrogen-binding energy $\left(\Delta G^{\circ} \mathrm{H} \sim 0\right)$ as Pt. Plane $\mathrm{MoS}_{2}$ was inactive for HER, but the edge of $\mathrm{MoS}_{2}$ had a bit positive $\Delta G^{\circ} \mathrm{H} \sim 0.1 \mathrm{eV}$ in a suitable range for HER. Graphite-supported $\mathrm{MoS}_{2}$ with enlarged edge area showed electrocatalytic HER with $0.1-0.2 \mathrm{~V}$ overpotential. 
Chorkendorff and coworkers could modify the $\mathrm{MoS}_{2}$ edge area by varying sintering temperature (Figure 4a) [170]. The $\mathrm{MoS}_{2}$ prepared from $400{ }^{\circ} \mathrm{C}$ sintering had a longer edge length than another case of $550^{\circ} \mathrm{C}$ sintering, and accordingly showed a higher HER current density of $3.1 \times 10^{-7} \mathrm{~A} / \mathrm{cm}^{2}$ compared to $1.3 \times 10^{-7} \mathrm{~A} / \mathrm{cm}^{2}$ of the latter. Albeit lower than the Pt electrode, the $\mathrm{MoS}_{2}$ edge exhibited higher current density than other common metal elements. They also showed photocatalytic HER activity of mixed MoS $S_{x}$ surface as deposited on Ti I $n^{+} p$-Si photocathode [171]. The $\mathrm{MoS}_{\mathrm{x}}$ was electrodeposited on Ti-protected $\mathrm{n}^{+} \mathrm{p}$-Si electrode by cyclic voltammetry (CV) scans at $0.137-1.247 \mathrm{~V}$ vs. RHE. The $\mathrm{MoS}_{\mathrm{x}}|\mathrm{Ti}| \mathrm{n}^{+} \mathrm{p}$-Si photocathode showed HER activity above $0.33 \mathrm{~V}$ vs. RHE under the illumination of red light.

The electrodeposition method seems to be not suitable to produce a large number of catalysts, and unstable species may not persist during cyclic voltammetry scans. Hu and coworkers reported that unsaturated $\mathrm{MoS}_{\mathrm{x}}$ provides a more active site for HER [172]. They prepared $\mathrm{MoS}_{\mathrm{x}}$ film by electro-polymerization method (Figure $4 \mathrm{~b}$ ), which exhibited higher catalytic activity than $\mathrm{MoS}_{2}$ single crystal and $\mathrm{MoS}_{2}$ nanoparticles. They explained that is because amorphous $\mathrm{MoS}_{\mathrm{x}}$ increases sulfur defects at the surface [173]. The same group investigated the effects of growth mechanism and catalyst mass, but they reported that the catalyst mass dominantly affected the catalytic efficiency (Figure 4c) [174].

Mo sulfur clusters have shown similar active sites as $\mathrm{MoS}_{2}$. Chorkendorff and coworkers adsorbed cubane type $\left[\mathrm{Mo}_{3} \mathrm{~S}_{4}\right]^{4+}$ cluster to highly oriented pyrolytic graphite [175]. $\left[\mathrm{Mo}_{3} \mathrm{~S}_{4}\right]^{4+}$ cluster showed similar overpotential as $\mathrm{MoS}_{2}$ nanoparticle. Even higher TOF of $0.07 \mathrm{~s}^{-1}$ was measured than $0.02 \mathrm{~s}^{-1}$ of $\mathrm{MoS}_{2}$ nanoparticle, but it was unstable during successive potential scanning.

Bensenbacher and coworkers synthesized $\left[\mathrm{Mo}_{3} \mathrm{~S}_{13}\right]^{2-}$ nanocluster by a wet chemical method of $\left(\mathrm{NH}_{4}\right)_{6} \mathrm{Mo}_{7} \mathrm{O}_{24}$ and ammonium polysulfide [176]. $\left[\mathrm{Mo}_{3} \mathrm{~S}_{13}\right]^{2-}$ showed HER activity at $0.1 \mathrm{~V}$ onset potential and $0.18 \mathrm{~V}$ overpotential at $10 \mathrm{~mA} / \mathrm{cm}^{2}\left(\mathrm{TOF} 3 \mathrm{~s}^{-1}\right)$. Li and coworkers synthesized $\mathrm{Mo}_{3} \mathrm{~S}_{13}$ film by electrodeposition, which showed a higher catalytic rate and lower overpotential by $\sim 40 \mathrm{mV}$ than $\mathrm{Mo}_{3} \mathrm{~S}_{13}$ film prepared by dropcasting of $\left(\mathrm{NH}_{4}\right)_{2} \mathrm{Mo}_{3} \mathrm{~S}_{13} \cdot 2 \mathrm{H}_{2} \mathrm{O}$ [177]. The increased electrical conductivity enhanced catalytic efficiency. $\mathrm{Xu}$ and coworkers improved HER efficiency by attaching $\left[\mathrm{Mo}_{3} \mathrm{~S}_{13}\right]^{2-}$ to highly conductive reduced graphene oxide-carbon nanotube (rGO-CNTs) aerogels, which recorded a lower overpotential by $74 \mathrm{mV}$ than pure $\left[\mathrm{Mo}_{3} \mathrm{~S}_{13}\right]^{2-}$ [178]. Wu and coworkers reported that dimeric $\left[\mathrm{Mo}_{2} \mathrm{~S}_{12}\right]^{2-}$ cluster slightly improved the HER activity by recording $0.16 \mathrm{~V}$ overpotential at $10 \mathrm{~mA} / \mathrm{cm}^{2}\left(\mathrm{TOF} \sim 3 \mathrm{~s}^{-1}\right)$ compared to $\left[\mathrm{Mo}_{3} \mathrm{~S}_{13}\right]^{2-}$ [179] They reported hydrogen adsorption free energy $\triangle \mathrm{G}_{\mathrm{ads}}(\mathrm{H})$ of $\left[\mathrm{Mo}_{2} \mathrm{~S}_{12}\right]^{2-}(-0.05 \mathrm{eV})$ is closer to zero than other surfaces such as $\left[\mathrm{Mo}_{3} \mathrm{~S}_{13}\right]^{2-}(-0.08 \mathrm{eV}), \mathrm{MoS}_{2}(0.08 \mathrm{eV})$, and $\mathrm{Pt}(111)(-0.09 \mathrm{eV})$.

Min and coworkers reported HER activity of $\left[\mathrm{Mo}_{3} \mathrm{~S}_{13}\right]^{2-}$ using $\left[\mathrm{Ru}(\mathrm{bpy})_{3}\right] \mathrm{Cl}_{2}$ and ascorbic acid under visible light $(\geq 420 \mathrm{~nm})$. Initial TOF of $335 \mathrm{~h}^{-1}$ was measured, but it had a problem of gradual decomposition [180]. The photocatalytic stability of $\left[\mathrm{Mo}_{3} \mathrm{~S}_{13}\right]^{2-}$ was improved by Zang and coworkers [181]. They encapsulated $\left[\mathrm{Mo}_{3} \mathrm{~S}_{13}\right]^{2-}$ in ethidium bromide covalent organic frameworks (EB-COFs). The COF-encapsulation did not decrease significantly the catalytic activity relative to a free $\left[\mathrm{Mo}_{3} \mathrm{~S}_{13}\right]^{2-}$ cluster. $\mathrm{Mo}_{3} \mathrm{~S}_{13} @ \mathrm{~EB}-\mathrm{COF}$ maintained photocatalytic HER for $8 \mathrm{~h}$ by recording $21,465 \mu \mathrm{mol} \mathrm{g}^{-1} \mathrm{~h}^{-1}$ rate, furthermore which showed the stable catalytic performance during the recycling test of 4 times of $5 \mathrm{~h}$ experiment.

Artero and coworkers studied the structure and reaction mechanism of amorphous $\operatorname{MoS}_{\mathrm{x}}\left(\alpha-\mathrm{MoS}_{\mathrm{x}}\right)$, which had polymer-based on $\left[\mathrm{Mo}_{3} \mathrm{~S}_{13}\right]^{2-}$ cluster sharing disulfide ligand [182]. They suggested that the reaction of terminal disulfide with proton and electron releases $\mathrm{HS}^{-}$to generate unsaturated $\mathrm{Mo}^{\mathrm{IV}}$ active site.

Octahedral molybdenum clusters are red near-IR phosphorescent emitters and showed high photocatalytic HER activity. Feliz and coworkers studied the catalytic performance of the (TBA) $)_{2}\left[\mathrm{Mo}_{6} \mathrm{Br}_{8}^{\mathrm{i}} \mathrm{F}_{6}^{\mathrm{a}}{ }_{6}\right](\mathrm{TBA}=$ tetra-n-butylammonium) cluster in aqueous solution in the presence of triethylamine (TEA) [183]. The catalytic activity of the $\left\{\mathrm{Mo}_{6} \mathrm{Br}^{\mathrm{i}}\right\}^{4+}$ 
cluster unit was enhanced by the in situ generation of the $\left[\mathrm{Mo}_{6} \mathrm{Br}^{\mathrm{i} 8} \mathrm{~F}_{5}{ }_{5}(\mathrm{OH})^{\mathrm{a}}\right]^{2-}$ and $\left[\mathrm{Mo}_{6} \mathrm{Br}_{8}{ }_{8} \mathrm{~F}_{3}{ }_{3}(\mathrm{OH})^{\mathrm{a}}\right]^{2-}$ and $\left[\mathrm{Mo}_{6} \mathrm{Br}_{8}{ }_{8}(\mathrm{OH})_{6}^{\mathrm{a}}\right]^{2-}$ species. In the same work, the cluster unit was coordinatively immobilized onto graphene oxide (GO) surfaces. The resulting material, (TBA) ${ }_{2} \mathrm{Mo}_{6} \mathrm{Br}_{8}{ }_{8} @ G O$, enhanced the cluster stability in a water $/ \mathrm{MeOH}$ mixture and under photoirradiation. Its catalytic performance was superior to that of GO, it decreased with respect to that of the molecular cluster complex. The TOF values with respect to atomic molybdenum were $5 \times 10^{-6} \mathrm{~s}^{-1}$ and $3 \times 10^{-4} \mathrm{~s}^{-1}$ for the heterogeneous and the homogeneous materials, respectively. Recently, the $(\mathrm{TBA})_{2}\left[\mathrm{Mo}_{6}{ }_{1}{ }^{\mathrm{i}}{ }_{8}\left(\mathrm{O}_{2} \mathrm{CCH}_{3}\right)^{\mathrm{a}}{ }_{6}\right]$ was also coordinatively immobilized onto GO to give (TBA) $)_{2} \mathrm{Mo}_{6} \mathrm{I}_{8} @ \mathrm{GO}$ [184]. To assure the cluster stability of the cluster units under photocatalytic conditions, both materials were tested in vapor water photoreduction. Even after longer radiation exposure times, the catalysts remained stable and recyclability of both catalysts was demonstrated. The TOF of (TBA) $)_{2} \mathrm{Mo}_{6} \mathrm{I}_{8}{ }_{8} @ G O$ is three times higher than that of the microcrystalline $(\mathrm{TBA})_{2}\left[\mathrm{Mo}_{6} \mathrm{I}_{8}{ }_{8}\left(\mathrm{O}_{2} \mathrm{CCH}_{3}\right)_{6}^{\mathrm{a}}\right]$, in agreement with the better accessibility of catalytic cluster sites for water molecules in the gas phase. In the framework of the study of the photocatalytic properties of the $\left\{\mathrm{Mo}_{6} \mathrm{I}_{8}\right\}^{4+}$ cluster units, one of the most emissive octahedral metal clusters, $\left[\mathrm{Mo}_{6} \mathrm{I}_{8}{ }_{8}\left(\mathrm{OCOC}_{2} \mathrm{~F}_{5}\right)_{6}{ }_{6}\right]^{2-}$, was immobilized onto graphene sheets through pyrene-containing organic cations as supramolecular linkers [185]. These non-covalent interactions enhanced the photocatalytic activity of the nanocomposite by $280 \%$ with respect to the molecular cluster and graphene counterparts. The improvement of the $\mathrm{H}_{2}$ production activity is attributed to the synergetic effect between graphene and the hybrid cluster complex because graphene facilitates the charge-separation activity and enhances electron transfer of the cluster photocatalyst.

Lana-Villarreal and coworkers reported photocatalytic HER activity of $\mathrm{Mo}_{3} \mathrm{~S}_{7}$ cluster as immobilized on $\mathrm{TiO}_{2}$ surface [186]. Functionalized bipyridyl ligand of $\mathrm{Mo}_{3} \mathrm{~S}_{7} \mathrm{Br}_{4}$ (diimino) cluster enabled adsorption of the cluster on $\mathrm{TiO}_{2}$ surface. The immobilized $\mathrm{Mo}_{3} \mathrm{~S}_{7}$ cluster decreased the HER overpotential by $0.3 \mathrm{~V}$ as recording $1.4 \mathrm{~s}^{-1}$ TOF. Despite the moderate catalytic activity, it gave an example to immobilize molecular cluster on electrode surface.

Fabrication of hetero-metal chalcogenides was an effective method to improve catalytic activities of Mo-based electrode materials. Doping of metal promoters possibly improves the intrinsic activity of unsaturated Mo sites. The electrocatalytic effect of $\mathrm{Cu} / \mathrm{Mo}$ heterometals was examined by Tran and coworkers [187]. $\mathrm{Cu}_{2} \mathrm{MoS}_{4}$ was synthesized by the solvothermal reaction of $\left[\mathrm{Cu}\left(\mathrm{CH}_{3} \mathrm{CN}\right)\right]\left(\mathrm{BF}_{4}\right)$ and $\left(\mathrm{NH}_{4}\right)_{2}\left[\mathrm{MoS}_{4}\right]$, and the obtained $\mathrm{Cu}_{2} \mathrm{MoS}_{4}$ crystals were stable under air for weeks.

Both $\mathrm{MoS}_{2}$ and $\mathrm{CoSe}_{2}$ were active for HER, and the synergistic effect of combined $\mathrm{MoS}_{2}$ and $\mathrm{CoSe}_{2}$ was examined by Gao and coworkers [188]. $\mathrm{MoS}_{2} / \mathrm{CoSe}_{2}$ showed the HER activity close to commercial $\mathrm{Pt} / \mathrm{C}$. Interaction of the first-row transition metal Co with $\mathrm{S}$ could form $\mathrm{S}^{2-}$ and $\mathrm{S}_{2}{ }^{2-}$ states, which possibly assisted $\mathrm{MoS}_{2}$ growth.

$\mathrm{MoSe}_{2}$ was relatively less studied compared to $\mathrm{MoS}_{2}$. Since the atomic hydrogen adsorption energy was measured to be lower with $\mathrm{MoSe}_{2}$ than that of $\mathrm{MoS}_{2}, \mathrm{MoSe}_{2}$ also showed an efficient HER activity [189]. Sasaki and coworkers improved corrosion stability of Ni/Mo-alloy by $\mathrm{NiMoN}_{\mathrm{x}}$ nanosheet, where metal stabilizing effect of nitride possibly improved the stability [190]. Mo phosphide (MoP) is a known hydrodesulfurization catalyst. Jaramillo and coworkers compared catalytic HER activity of crystalline MoP and molybdenum phosphosulfide (MoP/S) [191]. Both the MoP and MoP/S were active for HER, but MoP/S showed the higher electrocatalytic activity than MoP.

Electrocatalytic HER activities of commercial $\mathrm{MoB}$ and $\mathrm{Mo}_{2} \mathrm{C}$ have been reported [192]. Two electrode materials showed similar catalytic activity and were usable under both acidic and basic conditions, exhibiting similar activity and durability in continuous electrolysis for $48 \mathrm{~h}$.

Leonard and coworkers reported the synthesis of various Mo-carbide materials such as $\alpha-\mathrm{MoC}_{1-\mathrm{x}}, \beta-\mathrm{Mo}_{2} \mathrm{C}, \eta-\mathrm{MoC}$, and $\gamma-\mathrm{MoC}$ with different stacking sequences, and compared their HER activities [193]. The $\beta-\mathrm{Mo}_{2} \mathrm{C}, \eta-\mathrm{MoC}$, and $\gamma-\mathrm{MoC}$ had similar hexagonal crystal structure, but the stacking sequence of $\beta-\mathrm{Mo}_{2} \mathrm{C}$ was $\mathrm{ABAB}, \eta-\mathrm{MoC}$ was $\mathrm{ABCABC}$, and $\gamma-\mathrm{MoC}$ was AAAA packing. $\alpha-\mathrm{MoC}_{1-\mathrm{x}}$ had a cubic structure as $\mathrm{ABCABC}$ stacking sequence. 
The $\beta-\mathrm{Mo}_{2} \mathrm{C}$ showed the highest HER activity, and the catalytic activities of the others were obtained in the order of: $\gamma-\mathrm{MoC}>\eta-\mathrm{MoC}>\alpha-\mathrm{MoC}_{1-x}$. The $\gamma-\mathrm{MoC}$ showed stable catalytic activity with $-1.95 \mathrm{~mA} / \mathrm{cm}^{2}$ at $-340 \mathrm{mV}$ vs. RHE in the continuous electrolysis for $18 \mathrm{~h}$.

Nakanishi and coworkers reported the synthesis of Mo carbonitride (MoCN) nanomaterial [194]. The reaction of $\mathrm{Na}_{2} \mathrm{MoO}_{4}$ with diaminopyridine (DAP) in acidic condition gave DAP-bound Mo oxide, which was polymerized by $\mathrm{NaHCO}_{3} /\left(\mathrm{NH}_{4}\right)_{2} \mathrm{~S}_{2} \mathrm{O}_{8}$ as emitting $\mathrm{CO}_{2}$ gas. The $\mathrm{CO}_{2}$ emission step formed nano-sized (PDAP) $-2 \mathrm{H}^{+} / \mathrm{MoO}_{4}{ }^{2-}(\mathrm{PDAP}=$ polydiaminopyridine) complex causing a high density of the catalytically active site. Finally, the polymer was pyrolyzed at $800{ }^{\circ} \mathrm{C}$ to become MoCN nanomaterial (Figure 4f). MoCN nanomaterial showed the HER activity above $-0.05 \mathrm{~V}$ vs. RHE and reached $10 \mathrm{~mA} / \mathrm{cm}^{2}$ at $-0.14 \mathrm{~V}$ vs. RHE in sulfuric acid ( $\mathrm{pH} 1$ ) solution. MoCN nanomaterial had electrocatalytic stability during $1000 \mathrm{CV}$ scans between -0.35 and $0.2 \mathrm{~V}$ vs. RHE.

Yu and coworkers used hybrid phosphorous-doped nanoporous carbon (PC) and RGO to support $\mathrm{MoO}_{2}$ [195]. $\mathrm{MoO}_{2} @ P C-R G O$ had a carbon skeleton, which prevented aggregation of catalytically active $\mathrm{MoO}_{2}$ nanoparticles. Additionally, the synergistic combination of PC and RGO assisted to enhance the catalytic activity.

(a)

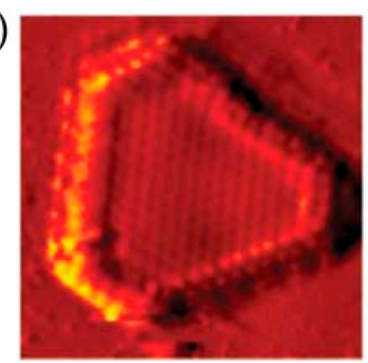

(d)

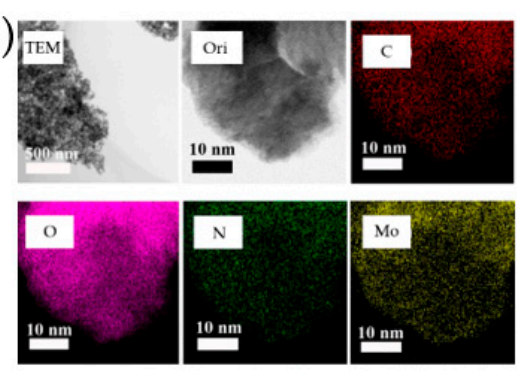

(b)

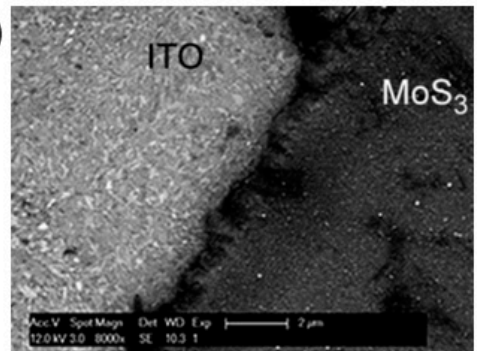

(e)

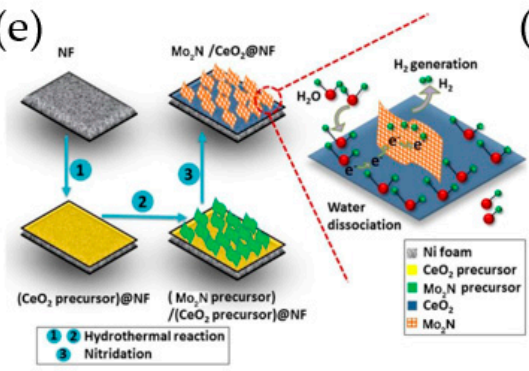

(c)

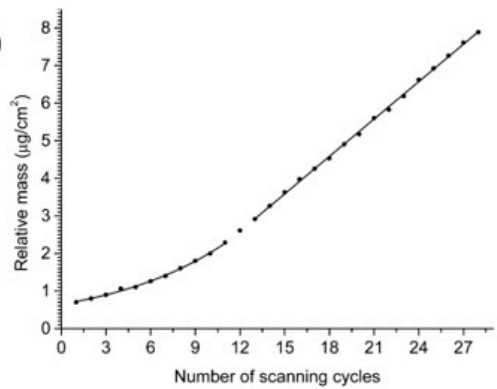

(f)

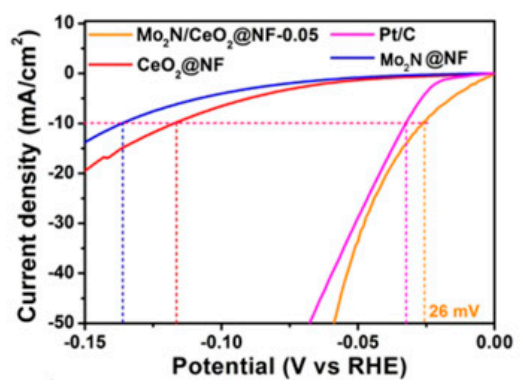

Figure 4. (a) STM image of atomically re-dissolved $\mathrm{MoS}_{2}$ particle on $\mathrm{Au}(111)$ [170]; (b) electron micrograph of $\mathrm{MoS}_{3}-\mathrm{CV}$ film on ITO [172]; (c) CV scan dependency of the mass of $\mathrm{MoS}_{2+x}$ film [174]; (d) TEM images (TEM, Ori) and EDS mapping of Mo carbonitride [194]; (e) synthetic process of $\mathrm{Mo}_{2} \mathrm{~N} / \mathrm{CeO}_{2} @ \mathrm{NF}$ [196]; (f) polarization curves of $\mathrm{Mo}_{2} \mathrm{~N} / \mathrm{CeO}_{2} @ \mathrm{NF}-0.05$, $20 \mathrm{wt} \% \mathrm{Pt} / \mathrm{C}, \mathrm{CeO}_{2} @ \mathrm{NF}$ and $\mathrm{Mo}_{2} \mathrm{~N} @ \mathrm{NF}$ [196]. Ref. [170] with permission from copyright 2007 American Association for the Advancement of Science, Ref. [172] with permission from the Royal Society of Chemistry, and Refs. [174,194,196] with permission from copyright American Chemical Society.

The use of adhesives for power-deposition on electrode generally lowers catalytic efficiency, so nickel foam (NF) has been used to prepare self-supported electrode. Huang and coworkers used NF to support $\mathrm{Mo}_{2} \mathrm{~N} / \mathrm{CeO}_{2}$ hetero-nanoparticles (Figure 4d) [196]. $\mathrm{CeO}_{2}$ was coated on $\mathrm{NF}$ by hydrothermal method, and the $\mathrm{CeO}_{2}$-fabricated $\mathrm{NF}$ was covered by $\mathrm{Mo}_{2} \mathrm{~N}$ with varying amounts of $\left(\mathrm{NH}_{4}\right)_{4} \mathrm{Mo}_{7} \mathrm{O}_{24} \cdot 4 \mathrm{H}_{2} \mathrm{O}(0.02,0.04,0.05,0.06 \mathrm{mmol})$ precursor by solvothermal method. Post-annealing at $500{ }^{\circ} \mathrm{C}$ for $5 \mathrm{~h}$ under $\mathrm{NH}_{3}$ atmosphere afforded $\mathrm{Mo}_{2} \mathrm{~N} / \mathrm{CeO}_{2} @ \mathrm{NF}$. The synthetic condition using $0.05 \mathrm{mmol}$ Mo source gave the best HER activity. $\mathrm{Mo}_{2} \mathrm{~N} / \mathrm{CeO}_{2} @ \mathrm{NF}-0.05$ sample showed smaller overpotential than commercial $20 \mathrm{wt} \% \mathrm{Pt} / \mathrm{C}$. The high catalytic activity was probably because electronic interaction between $\mathrm{Mo}_{2} \mathrm{~N}$ and $\mathrm{CeO}_{2}$ lowers the energy barrier for hydrogen intermediate formation (Figure 4e). The catalytic efficiencies of the above Mo-based HER electrocatalysts are compared in Table 3. 
Table 3. Compared catalytic efficiencies of Mo-based HER electrocatalysts.

\begin{tabular}{|c|c|c|c|c|c|}
\hline Catalyst & Onset Potential & Overpotential & $\begin{array}{l}\text { Tafel Slope } \\
\text { (mV/dec) }\end{array}$ & $\begin{array}{c}\text { Exchanged } \\
\text { Current Density } \\
\left(\mathrm{A} / \mathrm{cm}^{2}\right)\end{array}$ & Ref. \\
\hline $\mathrm{MoS}_{2}$ nanoparticles & - & - & $55 \sim 60$ & $1.3 \times 10^{-7}$ & [170] \\
\hline$\left[\mathrm{Mo}_{3} \mathrm{~S}_{4}\right]^{4+}$ cluster & $-0.2 \mathrm{~V}$ vs. NHE & - & 120 & $2.2 \times 10^{-7}$ & [175] \\
\hline $\begin{array}{l}\mathrm{MoS}_{\mathrm{x}}|\mathrm{Ti}| \mathrm{n}^{+} \mathrm{p}-\mathrm{Si} \\
\text { photocathode }\end{array}$ & $0.33 \mathrm{~V}$ vs. RHE & - & 39 & - & [171] \\
\hline $\mathrm{MoS}_{3}-\mathrm{CV}$ & - & $200 \mathrm{mV}$ at $-15 \mathrm{~mA} / \mathrm{cm}^{2}$ & 40 & $1.3 \times 10^{-7}$ & [172] \\
\hline amorphous $\mathrm{MoS}_{3}$ & - & $200 \mathrm{mV}$ at $-4.8 \mathrm{~mA} / \mathrm{cm}^{2}$ & 42 & - & [173] \\
\hline $\mathrm{MoS}_{2+x}$ film & - & $170 \mathrm{mV}$ at $-20 \mathrm{~mA} / \mathrm{cm}^{2}$ & - & - & [174] \\
\hline $\mathrm{MoSe}_{2}$ nanosheets & $-0.15 \mathrm{~V}$ vs. RHE & $290 \mathrm{mV}$ at $-10 \mathrm{~mA} / \mathrm{cm}^{2}$ & 101 & - & [189] \\
\hline $\mathrm{MoSe}_{2} \mid \mathrm{RGO}$ & $-0.05 \mathrm{~V}$ vs. RHE & $115 \mathrm{mV}$ at $-10 \mathrm{~mA} / \mathrm{cm}^{2}$ & 69 & - & [189] \\
\hline $\mathrm{Cu}_{2} \mathrm{MoS}_{4}$ & & $135 \mathrm{mV}$ (onset) & 95 & $4.0 \times 10^{-5}$ & [187] \\
\hline $\mathrm{MoS}_{2} / \mathrm{CoSe}_{2}$ & $-11 \mathrm{mV}$ vs. RHE & $68 \mathrm{mV}$ at $-10 \mathrm{~mA} / \mathrm{cm}^{2}$ & 36 & $7.3 \times 10^{-5}$ & [188] \\
\hline $\mathrm{NiMoN}_{\mathrm{x}}$ nanosheet & $-78 \mathrm{mV}$ vs. RHE & - & 35.9 & $2.4 \times 10^{-4}$ & [190] \\
\hline commercial MoB & & $100 \mathrm{mV}$ (onset) & 55 & $1.4 \times 10^{-6}$ & [192] \\
\hline commercial $\mathrm{Mo}_{2} \mathrm{C}$ & & $100 \mathrm{mV}$ (onset) & 56 & $1.3 \times 10^{-6}$ & [192] \\
\hline $\mathrm{MoP} / \mathrm{S}$ & - & $90 \mathrm{mV}$ at $-10 \mathrm{~mA} / \mathrm{cm}^{2}$ & 50 & $2.0 \times 10^{-4}$ & [191] \\
\hline MoP & - & $117 \mathrm{mV}$ at $-10 \mathrm{~mA} / \mathrm{cm}^{2}$ & 50 & $5.0 \times 10^{-5}$ & [191] \\
\hline$\gamma-\mathrm{MoC}$ & $\begin{array}{l}-0.24 \mathrm{~V} \text { vs. RHE } \\
\left(\text { at } 0.18 \mathrm{~mA} / \mathrm{cm}^{2}\right)\end{array}$ & - & 121.6 & $3.2 \times 10^{-6}$ & [193] \\
\hline Mo carbonitride & $-0.05 \mathrm{~V}$ vs. RHE & - & $46 \sim 51$ & - & [194] \\
\hline $\mathrm{MoO}_{2} @ P C-R G O$ & $0 \mathrm{~V}$ vs. RHE & $64 \mathrm{mV}$ at $-10 \mathrm{~mA} / \mathrm{cm}^{2}$ & 41 & $4.8 \times 10^{-4}$ & [195] \\
\hline $\mathrm{Mo}_{2} \mathrm{~N} / \mathrm{CeO}_{2} @ \mathrm{NF}-0.05$ & - & $26 \mathrm{mV}$ at $-10 \mathrm{~mA} / \mathrm{cm}^{2}$ & 37.8 & - & [196] \\
\hline$\left[\mathrm{Mo}_{3} \mathrm{~S}_{13}\right]^{2-}$ nanocluster & & $180 \mathrm{mV}$ at $-10 \mathrm{~mA} / \mathrm{cm}^{2}$ & 40 & & [176] \\
\hline $\mathrm{Mo}_{3} \mathrm{~S}_{13}$ film & $-130 \mathrm{mV}$ vs. RHE & $200 \mathrm{mV}$ at $-10 \mathrm{~mA} / \mathrm{cm}^{2}$ & 37 & & [177] \\
\hline $\begin{array}{c}{\left[\mathrm{Mo}_{3} \mathrm{~S}_{13}\right]^{2-} \text { attached at }} \\
\text { (rGO-CNTs) aerogels }\end{array}$ & $-110 \mathrm{mV}$ vs. RHE & $179 \mathrm{mV}$ at $-10 \mathrm{~mA} / \mathrm{cm}^{2}$ & 60.2 & & [178] \\
\hline $\begin{array}{c}\text { dimeric }\left[\mathrm{Mo}_{2} \mathrm{~S}_{12}\right]^{2-} \\
\text { cluster }\end{array}$ & & $161 \mathrm{mV}$ at $-10 \mathrm{~mA} / \mathrm{cm}^{2}$ & 39 & & [179] \\
\hline
\end{tabular}

\section{Heterogeneous Mo-Containing $\mathrm{O}_{2}$-Evolution Electrocatalysts}

Water splitting is an ideal method for the conversion of electric and solar energy to the chemical bond energy of dihydrogen. However, oxidation of water to $\mathrm{O}_{2}$, the counterpart reaction of $\mathrm{H}_{2}$ evolution, is kinetically slow, which decreases the overall efficiency of the water-splitting reaction. Since oxygen evolution reaction (OER) is a multi-electron process demanding large overpotential, efficient electrocatalysts are highly desired. $\mathrm{RuO}_{2}$ is a benchmark catalyst for the OER, but the high cost and easy decomposition to $\mathrm{RuO}_{4}$ are drawbacks of using Ru. Research efforts have been made to develop Earth-abundant metal-based electrocatalysts with high-performance and durability, and, among those, Mo-containing electrocatalysts have shown promising OER activities.

$\mathrm{MoS}_{2}$ edge site is also known to be active for the OER, and, thus, various synthetic methods were developed to enlarge the edge site area. Mohanty and coworkers investigated the OER activity of $\mathrm{MoS}_{2}$ quantum dots [197]. The $\mathrm{MoS}_{2}$ quantum dot compounds (MSQDs) of 2-5 nm size were synthesized without aggregation through single-step hydrothermal reaction using $\left.\left(\mathrm{NH}_{4}\right)_{2} \mathrm{MoS}_{4}\right)$ precursor (Figure 5a,b). Repeating linear sweep 
voltammetry (LSV) scans up to 50 cycles increased the OER current density, because the electrochemically active surface area of MSQDs was enlarged with the potential scans.

Direct growing methods, useful to increase contact, conductivity, and electron transfer, are generally applied to prepare OER electrocatalysts. In 2016, Yan and Lu prepared a porous $\mathrm{MoS}_{2}$ microsphere on nickel foam (NF) [198]. The $\mathrm{MoS}_{2}$ on NF showed a higher catalytic rate $\left(105 \mathrm{mV} /\right.$ dec Tafel slope) than commercial $\mathrm{RuO}_{2}$ on NF $(127 \mathrm{mV} / \mathrm{dec})$ and $20 \% \mathrm{Pt} / \mathrm{C}\left(150 \mathrm{mV} \mathrm{dec}^{-1}\right)$. Cui and coworkers synthesized mesoporous $\mathrm{MoO}_{2}$ nanosheets on NF [199]. The mesoporosity of $\mathrm{MoO}_{2}$ enlarged the active surface area and slightly improved the catalytic activity than that of compact $\mathrm{MoO}_{2}$.

Boride increases a reverse electron transfer to the metal site, which accordingly increases electron density on the catalytic site. Gupta and coworkers synthesized ternary Co-Mo-B hetero-metal nanocomposite, which gave enhanced OER activity [200].

$\mathrm{Li}$ and coworkers used a well-defined $\mathrm{Cu}$ nanowire to deposit Ni/Mo-alloy catalyst [201]. Alkaline anodization and subsequent cathodic reduction process modified the surface of $\mathrm{Cu}$ foam. A mixture of $\mathrm{Ni}\left(\mathrm{SO}_{3} \mathrm{NH}_{2}\right)_{2}$ and $\mathrm{Na}_{2} \mathrm{MoO}_{4}$ were electrodeposited on the $\mathrm{Cu}$ nano-scaffold to obtain $\mathrm{Ni}-\mathrm{Mo} / \mathrm{Cu}$ nanowire. The $\mathrm{Ni}-\mathrm{Mo} / \mathrm{Cu}$ nanowire exhibited comparable OER activity with commercial $\mathrm{Pt} / \mathrm{C}\left(\mathrm{RuO}_{2}\right)$ on $\mathrm{Cu}$ foam.

Yang and coworkers examined the synergistic effect of trimetallic FeCoMo nanocomposite for the OER test [202]. Amorphous FeCoMo nanocomposite was synthesized as a rodlike shape by hydrolysis of a mixture of $\mathrm{CoCl}_{2} \cdot 6 \mathrm{H}_{2} \mathrm{O}, \mathrm{FeCl}_{3} \cdot 6 \mathrm{H}_{2} \mathrm{O}$ and $\left(\mathrm{NH}_{4}\right)_{6} \mathrm{Mo}_{7} \mathrm{O}_{24} \cdot 4 \mathrm{H}_{2} \mathrm{O}$, hexamethylene tetramine at $90{ }^{\circ} \mathrm{C}$. The existence of high-valent $\mathrm{Mo}^{6+}$ was characterized by Raman spectroscopy. In situ X-ray absorption near edge structure (XANES) showed that $\mathrm{Mo}^{6+}$ tends to attract electrons from $3 \mathrm{~d}$ transition metals, which possibly promoted the OER process.

Gao and coworkers prepared a bifunctional catalyst using $\mathrm{MoS}_{2}$ HER catalyst and $\mathrm{Ni}_{3} \mathrm{~S}_{2}$ OER catalyst (Figure $5 \mathrm{c}-\mathrm{e}$ ) [203]. $\mathrm{MoS}_{2}-\mathrm{Ni}_{3} \mathrm{~S}_{2}$ heteronanorods on NF afforded higher OER activity than $\mathrm{Ni}_{3} \mathrm{~S}_{2} / \mathrm{NF}$ and $\mathrm{MoS}_{2} / \mathrm{NF}$.

The bimetallic system enables manipulation of electronic structure and gives abundant active sites, but a synthesis of pure phase is difficult. Lan and coworkers could make purephase bimetallic Co/Mo carbides using mesoporous carbon substrate (Figure 5f) [204]. Transition metal carbide also gave the high catalytic activity because of the good electrical conductivity, metallic property, and chemical stability.

$\mathrm{Ni}$ oxyhydroxide is an active site for OER, but the low stability decreases the catalytic efficiency. Shen and coworkers increased the stability by fabricating $\mathrm{MoFe}: \mathrm{Ni}(\mathrm{OH})_{2} / \mathrm{NiOOH}$ nanosheet and studied synergistic effect [205].

$\mathrm{Ma}$ and coworkers synthesized one-dimensional $\mathrm{MoO}_{2}-\mathrm{Co}_{2} \mathrm{Mo}_{3} \mathrm{O}_{8} @ \mathrm{C}$ nanorods with the enlarged catalytic surface area [206]. The ZIF-67 MOF was attached to $\mathrm{MoO}_{3}$ nanorods to form $\mathrm{MoO}_{3} @ \mathrm{ZIF}-67$, and subsequent hydrothermal reaction at $700{ }^{\circ} \mathrm{C}$ gave $\mathrm{MoO}_{2}$ $\mathrm{Co}_{2} \mathrm{Mo}_{3} \mathrm{O}_{8} @ \mathrm{C}$ nanorods (containing Co/Mo in 9.1/10.5\% ratio). The organic ligand of ZIF-67 was carbonized into carbon, which served as a reductant to reduce excess $\mathrm{MoO}_{3}$ to $\mathrm{MoO}_{2}$. The $\mathrm{MoO}_{2}-\mathrm{Co}_{2} \mathrm{Mo}_{3} \mathrm{O}_{8} @ \mathrm{C}$ nanorods showed similar activity as the benchmark $\mathrm{RuO}_{2}$.

Yang and coworkers studied the OER activity of $\mathrm{Ni}_{2} \mathrm{Mo}_{3} \mathrm{~N}$ hetero-metal nitride [207]. They reported that an amorphous surface oxygen-rich activation layer (SOAL) was generated on $\mathrm{Ni}_{2} \mathrm{Mo}_{3} \mathrm{~N}$ nanoparticle surface by applying high oxidative potential in alkaline conditions. The computational study suggested that SOAL could increase the OER activity, because the conjugation of Ni-nitrides active sites and the secondary Mo-electron pump promoted the catalytic reaction.

Jiang and coworkers reported the synergistic effect of $\mathrm{Co}_{3} \mathrm{Mo}$ alloy nanoparticles as attached to nanoporous $\mathrm{Cu}$ skeleton [208]. They synthesized Mo-doped $\mathrm{Co}_{3} \mathrm{O}_{4}$ nanoflakes on $\mathrm{CuO} / \mathrm{Cu}$ skeleton by electro-oxidation (EO) at $1.57 \mathrm{~V}$ vs. $\mathrm{RHE}$. The $\mathrm{EO} \mathrm{Co}_{3} \mathrm{Mo} / \mathrm{Cu}$ showed lower OER onset overpotential than $\mathrm{Ir} / \mathrm{C}$ supported by nanoporous $\mathrm{Cu}$. Since $\mathrm{Co}_{3} \mathrm{Mo} / \mathrm{Cu}$ also acted as a highly active HER catalyst, they composed a water electrolysis set-up by $\mathrm{Co}_{3} \mathrm{Mo} / \mathrm{Cu}$ cathode and $\mathrm{EO} \mathrm{Co}_{3} \mathrm{Mo} / \mathrm{Cu}$ anode. The $\mathrm{Co}_{3} \mathrm{Mo} / \mathrm{Cu}$-based electrolyzer showed overall water splitting delivering a current density of $100 \mathrm{~mA} / \mathrm{cm}^{2}$ at $1.62 \mathrm{~V}$ vs. RHE. The 
water-splitting system acted more efficiently than $\mathrm{Pt} / \mathrm{C} / \mathrm{Cu}-\mathrm{Ir} / \mathrm{C} / \mathrm{Cu}$ set-up (Figure 5g,h). The catalytic efficiency parameters of the Mo-based OER electrocatalysts are compared in Table 4.
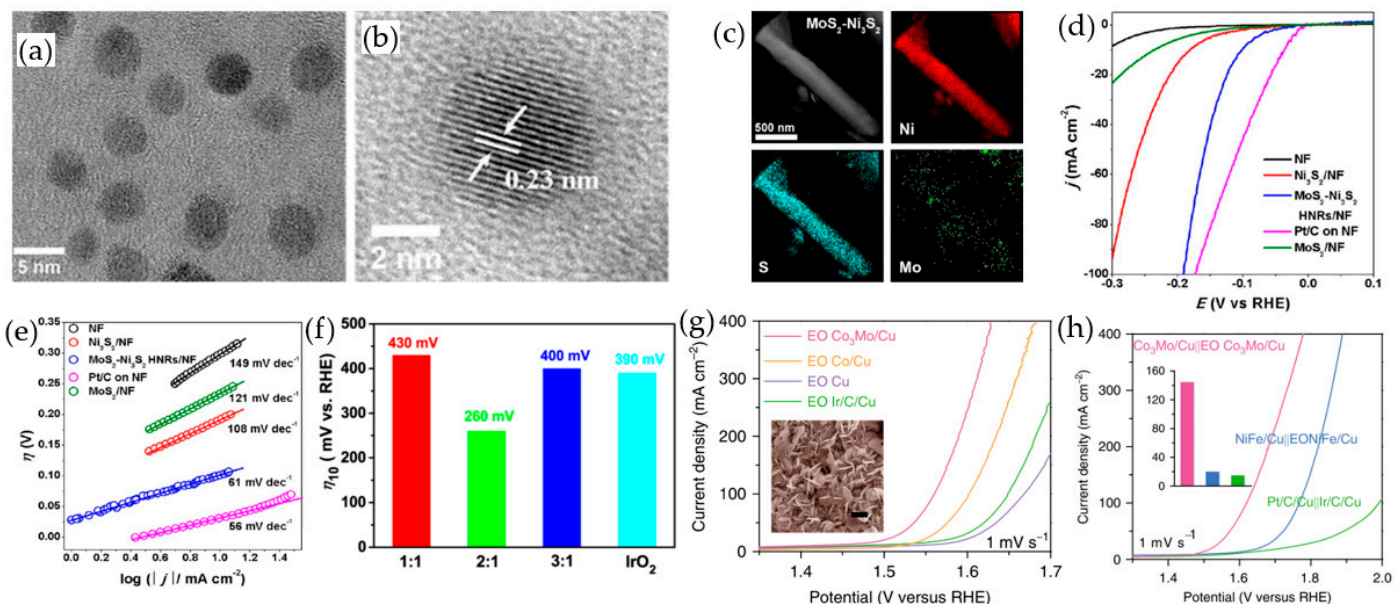

Figure 5. (a,b) HRTEM images of MSQCs [197]; (c) EDS and elemental mapping of $\mathrm{MoS}_{2}-\mathrm{Ni}_{3} \mathrm{~S}_{2}$ heteronanorods [203]; (d) polarization curves and (e) Tafel slopes of NF, $\mathrm{Ni}_{3} \mathrm{~S}_{2} / \mathrm{NF}, \mathrm{MoS}_{2}-\mathrm{Ni}_{3} \mathrm{~S}_{2} \mathrm{HNRs} / \mathrm{NF}$, and Pt/C on NF and MoS $/$ NF [203]; (f) overpotentials of $\mathrm{IrO}_{2}$ and $\mathrm{Co} / \mathrm{Mo}$ carbides $\left(\mathrm{Co}_{6} \mathrm{Mo}_{6} \mathrm{C}_{2} / \mathrm{NCRGO}\right.$ with different $\mathrm{Co} / \mathrm{Mo}$ ratios 1:1, 2:1, 3:1) at $10 \mathrm{~mA} / \mathrm{cm}^{2}$ [204]; (g) polarization curves of $\mathrm{EO} \mathrm{Co}_{3} \mathrm{Mo} / \mathrm{Cu}, \mathrm{EO} \mathrm{Co} / \mathrm{Cu}, \mathrm{EO} \mathrm{Cu}$, and $\mathrm{Ir} / \mathrm{C} / \mathrm{Cu}$ (Inset: SEM image of $\mathrm{EO} \mathrm{Co}_{3} \mathrm{Mo} / \mathrm{Cu}$ ) [208]; and (h) polarization curves for electrocatalytic water splitting of nanoporous $\mathrm{Co}_{3} \mathrm{Mo} / \mathrm{Cu}$ and $\mathrm{EO} \mathrm{Co}_{3} \mathrm{Mo} / \mathrm{Cu}$ electrodes, nanoporous $\mathrm{NiFe} / \mathrm{Cu}$ and $\mathrm{EO} \mathrm{NiFe} / \mathrm{Cu}$ electrodes and $\mathrm{Pt} / \mathrm{C} / \mathrm{Cu}$ and $\mathrm{Ir} / \mathrm{C} / \mathrm{Cu}$, Inset: Comparison of current density at 1.65 V [208]. Reproduced from Refs. [197,203,204] with permission from copyright American Chemical Society and Ref. [208] with permission from copyright 2020 Springer Nature.

Table 4. Onset potentials, overpotentials, Tafel slopes Mo-based OER catalysts.

\begin{tabular}{|c|c|c|c|c|}
\hline Catalyst & $\begin{array}{l}\text { Current Density } \\
\quad\left(\mathrm{mA} / \mathrm{cm}^{2}\right)\end{array}$ & Overpotential & Tafel Slope (mV/dec) & Ref. \\
\hline $\mathrm{MoS}_{2}$ on NF & 20 & $310 \mathrm{mV}$ & 105 & [198] \\
\hline Mesoporous $\mathrm{MoO}_{2}$ nanosheets on NF & 10 & $260 \mathrm{mV}$ & 54 & [199] \\
\hline Co-Mo-B & 10 & $320 \mathrm{mV}$ & 56 & [200] \\
\hline $\mathrm{Ni}-\mathrm{Mo} / \mathrm{Cu}$ nanowire & 20 & $280 \mathrm{mV}$ & 66 & [201] \\
\hline FeCoMo nanocomposite & 10 & $277 \mathrm{mV}$ & 27.74 & [202] \\
\hline $\mathrm{MoS}_{2}-\mathrm{Ni}_{3} \mathrm{~S}_{2}$ heteronanorods & 10 & $249 \mathrm{mV}$ & 57 & [203] \\
\hline bimetallic Co/Mo carbides & 10 & $260 \mathrm{mV}$ & 50 & [204] \\
\hline MoFe:Ni(OH $)_{2} / \mathrm{NiOOH}$ nanosheet & 100 & $280 \mathrm{mV}$ & 47 & [205] \\
\hline MSQDs-AC & 10 & $370 \mathrm{mV}$ & 39 & [197] \\
\hline $\mathrm{MoO}_{2}-\mathrm{Co}_{2} \mathrm{Mo}_{3} \mathrm{O}_{8} @ \mathrm{C}$ nanorods & 10 & $320 \mathrm{mV}$ & 88 & [206] \\
\hline $\mathrm{Ni}_{2} \mathrm{Mo}_{3} \mathrm{~N}$ hetero-metal nitride & 10 & $270 \mathrm{mV}$ & 59 & [207] \\
\hline $\mathrm{EO} \mathrm{Co}_{3} \mathrm{Mo}$ alloy nanoparticles & 164 & $350 \mathrm{mV}$ & 82 & [208] \\
\hline
\end{tabular}

\section{Conclusions}

This review summarizes Mo-containing metalloenzymes and their model complexes, homogeneous and heterogeneous catalysts under categories of reactivities with $\mathrm{CO}_{2}, \mathrm{~N}_{2}$, $\mathrm{H}_{2}$, and $\mathrm{O}_{2}$. Compared to the Mo enzymes, catalytic activities of synthetic systems remain at a low-efficiency level. Thus, continuous research efforts in synthetic and theoretical perspectives are requested to achieve high-performing catalysts. The revealed Mo-enzyme 
structures enabled synthetic research on the enzyme reactivities, and concomitant theoretical studies gave an in-depth understanding of the enzyme mechanism. However, previously proposed mechanisms need further supports by synthetic experiments, and spectroscopic research on living cells still has limitations; thus, more active modeling studies are required.

Along with the modeling studies, new catalysts by ligand design should be developed to find an optimal condition to prepare active Mo ion. Ligand design for a low-valent Mo ion to function under lower gas pressure is pursued. Examples of homogeneous catalysts using high-valent Mo ions are relatively rare. Mimicking the enzyme active site partially or conceptually could provide synthetic ideas to develop both low- and high-valent Mo-based catalysts. In addition, catalytic stability of the Mo complex is a prerequisite for commercialization. Utilization of hetero-metallic surface is a method of preventing deactivation of catalytic sites as well as providing synergistic effects. Another method would be to use polymer or organic scaffold for regulating access of reagents into a catalytic site, which is similar to the enzymatic strategy to protect the active site by surrounding it with polypeptide chains.

Funding: This work was supported by the National Research Foundation of Korea (NRF) grant funded by the Korea government (MSIT) (No. 2020R1C1C1007106) and GIST Research Institute (GRI) grant funded by the GIST in 2020 .

Conflicts of Interest: The authors declare no conflict of interest.

\section{References}

1. van der Ham, C.J.M.; Koper, M.T.M.; Hetterscheid, D.G.H. Challenges in reduction of dinitrogen by proton and electron transfer. Chem. Soc. Rev. 2014, 43, 5183-5191. [CrossRef] [PubMed]

2. John, J.; Lee, D.-K.; Sim, U. Photocatalytic and electrocatalytic approaches towards atmospheric nitrogen reduction to ammonia under ambient conditions. Nano Converg. 2019, 6, 15. [CrossRef]

3. He, M.; Sun, Y.; Han, B. Green Carbon Science: Scientific Basis for Integrating Carbon Resource Processing, Utilization, and Recycling. Angew. Chem. Int. Ed. 2013, 52, 9620-9633. [CrossRef]

4. Zou, X.; Zhang, Y. Noble metal-free hydrogen evolution catalysts for water splitting. Chem. Soc. Rev. 2015, 44, 5148-5180. [CrossRef] [PubMed]

5. Walter, M.G.; Warren, E.L.; McKone, J.R.; Boettcher, S.W.; Mi, Q.; Santori, E.A.; Lewis, N.S. Solar Water Splitting Cells. Chem. Rev. 2010. [CrossRef] [PubMed]

6. Rosca, V.; Duca, M.; de Groot, M.T.; Koper, M.T.M. Nitrogen Cycle Electrocatalysis. Chem. Rev. 2009, 109, 2209-2244. [CrossRef] [PubMed]

7. Jiao, Y.; Zheng, Y.; Jaroniec, M.; Qiao, S.Z. Design of electrocatalysts for oxygen- and hydrogen-involving energy conversion reactions. Chem. Soc. Rev. 2015, 44, 2060-2086. [CrossRef]

8. Janani, G.; Choi, H.; Surendran, S.; Sim, U. Recent advances in rational design of efficient electrocatalyst for full water splitting across all pH conditions. MRS Bull. 2020, 45, 539-547. [CrossRef]

9. Andreini, C.; Bertini, I.; Cavallaro, G.; Holliday, G.L.; Thornton, J.M. Metal ions in biological catalysis: From enzyme databases to general principles. J. Biol. Inorg. Chem. 2008, 13, 1205-1218. [CrossRef]

10. Bullock, R.M.; Chen, J.G.; Gagliardi, L.; Chirik, P.J.; Farha, O.K.; Hendon, C.H.; Jones, C.W.; Keith, J.A.; Klosin, J.; Minteer, S.D.; et al. Using nature's blueprint to expand catalysis with Earth-abundant metals. Science 2020, 369. [CrossRef]

11. Eckenhoff, W.T.; Brennessel, W.W.; Eisenberg, R. Light-Driven Hydrogen Production from Aqueous Protons using Molybdenum Catalysts. Inorg. Chem. 2014, 53, 9860-9869. [CrossRef]

12. Dos Santos, P.C.; Dean, D.R.; Hu, Y.; Ribbe, M.W. Formation and Insertion of the Nitrogenase Iron-Molybdenum Cofactor. Chem. Rev. 2004, 104, 1159-1174. [CrossRef]

13. Dobbek, H. Structural aspects of mononuclear Mo/W-enzymes. Coord. Chem. Rev. 2011, 255, 1104-1116. [CrossRef]

14. Cordas, C.M.; Moura, J.J.G. Molybdenum and tungsten enzymes redox properties-A brief overview. Coord. Chem. Rev. 2019, 394, 53-64. [CrossRef]

15. Lin, Y.-W. Rational Design of Artificial Metalloproteins and Metalloenzymes with Metal Clusters. Molecules 2019, $24,2743$. [CrossRef] [PubMed]

16. Zhu, J.; Hu, L.; Zhao, P.; Lee, L.Y.S.; Wong, K.-Y. Recent Advances in Electrocatalytic Hydrogen Evolution Using Nanoparticles. Chem. Rev. 2020. [CrossRef] [PubMed]

17. Yang, L.; Liu, P.; Li, J.; Xiang, B. Two-Dimensional Material Molybdenum Disulfides as Electrocatalysts for Hydrogen Evolution. Catalysts 2017, 7, 285. [CrossRef] 
18. Zhang, S.; Fan, Q.; Xia, R.; Meyer, T.J. $\mathrm{CO}_{2}$ Reduction: From Homogeneous to Heterogeneous Electrocatalysis. Acc. Chem. Res. 2020, 53, 255-264. [CrossRef]

19. Axley, M.J.; Grahame, D.A. Kinetics for formate dehydrogenase of Escherichia coli formate-hydrogenlyase. J. Biol. Chem. 1991, 266, 13731-13736. [CrossRef]

20. Appel, A.M.; Bercaw, J.E.; Bocarsly, A.B.; Dobbek, H.; DuBois, D.L.; Dupuis, M.; Ferry, J.G.; Fujita, E.; Hille, R.; Kenis, P.J.A.; et al. Frontiers, Opportunities, and Challenges in Biochemical and Chemical Catalysis of $\mathrm{CO}_{2}$ Fixation. Chem. Rev. 2013, 113, 6621-6658. [CrossRef]

21. Hille, R.; Hall, J.; Basu, P. The Mononuclear Molybdenum Enzymes. Chem. Rev. 2014, 114, 3963-4038. [CrossRef]

22. Hartmann, T.; Leimkühler, S. The oxygen-tolerant and NAD+-dependent formate dehydrogenase from Rhodobacter capsulatus is able to catalyze the reduction of $\mathrm{CO}_{2}$ to formate. FEBS J. 2013, 280, 6083-6096. [CrossRef]

23. Maia, L.B.; Fonseca, L.; Moura, I.; Moura, J.J.G. Reduction of Carbon Dioxide by a Molybdenum-Containing Formate Dehydrogenase: A Kinetic and Mechanistic Study. J. Am. Chem. Soc. 2016, 138, 8834-8846. [CrossRef] [PubMed]

24. Boyington, J.C.; Gladyshev, V.N.; Khangulov, S.V.; Stadtman, T.C.; Sun, P.D. Crystal structure of formate dehydrogenase H: Catalysis involving Mo, molybdopterin, selenocysteine, and an Fe4S4 cluster. Science 1997, 275, 1305-1308. [CrossRef] [PubMed]

25. Raaijmakers, H.C.A.; Romao, M.J. Formate-reduced E-coli formate dehydrogenase H: The reinterpretation of the crystal structure suggests a new reaction mechanism. J. Biol. Inorg. Chem. 2006, 11, 849-854. [CrossRef]

26. Mota, C.S.; Rivas, M.G.; Brondino, C.D.; Moura, I.; Moura, J.J.G.; González, P.J.; Cerqueira, N.M.F.S.A. The mechanism of formate oxidation by metal-dependent formate dehydrogenases. J. Biol. Inorg. Chem. 2011, 16, 1255-1268. [CrossRef]

27. Cerqueira, N.M.F.S.A.; Fernandes, P.A.; Gonzalez, P.J.; Moura, J.J.G.; Ramos, M.J. The Sulfur Shift: An Activation Mechanism for Periplasmic Nitrate Reductase and Formate Dehydrogenase. Inorg. Chem. 2013, 52, 10766-10772. [CrossRef] [PubMed]

28. Schrapers, P.; Hartmann, T.; Kositzki, R.; Dau, H.; Reschke, S.; Schulzke, C.; Leimkuhler, S.; Haumann, M. Sulfido and Cysteine Ligation Changes at the Molybdenum Cofactor during Substrate Conversion by Formate Dehydrogenase (FDH) from Rhodobacter capsulatus. Inorg. Chem. 2015, 54, 3260-3271. [CrossRef]

29. Duffus, B.R.; Schrapers, P.; Schuth, N.; Mebs, S.; Dau, H.; Leimkuhler, S.; Haumann, M. Anion Binding and Oxidative Modification at the Molybdenum Cofactor of Formate Dehydrogenase from Rhodobacter capsulatus Studied by X-ray Absorption Spectroscopy. Inorg. Chem. 2020, 59, 214-225. [CrossRef]

30. Hille, R.; Dingwall, S.; Wilcoxen, J. The aerobic CO dehydrogenase from Oligotropha carboxidovorans. J. Biol. Inorg. Chem. 2015, 20, 243-251. [CrossRef]

31. Dobbek, H.; Gremer, L.; Kiefersauer, R.; Huber, R.; Meyer, O. Catalysis at a dinuclear $[\mathrm{CuSMo}(=\mathrm{O}) \mathrm{OH}] \mathrm{cluster}$ in a CO dehydrogenase resolved at 1.1-A resolution. Proc. Natl. Acad. Sci. USA 2002, 99, 15971-15976. [CrossRef]

32. Gnida, M.; Ferner, R.; Gremer, L.; Meyer, O.; Meyer-Klaucke, W. A Novel Binuclear [CuSMo] Cluster at the Active Site of Carbon Monoxide Dehydrogenase: Characterization by X-ray Absorption Spectroscopy. Biochemistry 2003, 42, 222-230. [CrossRef] [PubMed]

33. Siegbahn, P.E.M.; Shestakov, A.F. Quantum chemical modeling of CO oxidation by the active site of molybdenum CO dehydrogenase. J. Comput. Chem. 2005, 26, 888-898. [CrossRef]

34. Hofmann, M.; Kassube, J.K.; Graf, T. The mechanism of Mo-/Cu-dependent CO dehydrogenase. J. Biol. Inorg.Chem. 2005, 10, 490-495. [CrossRef] [PubMed]

35. Zhang, B.; Hemann, C.F.; Hille, R. Kinetic and spectroscopic studies of the molybdenum-copper CO dehydrogenase from Oligotropha carboxidovorans. J. Biol. Chem. 2010, 285, 12571-12578. [CrossRef]

36. Seo, J.; Kim, E. O-Atom Exchange between $\mathrm{H}_{2} \mathrm{O}$ and $\mathrm{CO}_{2}$ Mediated by a Bis(dithiolene)tungsten Complex. Inorg. Chem. 2012, 51, 7951-7953. [CrossRef] [PubMed]

37. Lim, B.S.; Holm, R.H. Bis(Dithiolene)molybdenum Analogues Relevant to the DMSO Reductase Enzyme Family: Synthesis, Structures, and Oxygen Atom Transfer Reactions and Kinetics. J. Am. Chem. Soc. 2001, 123, 1920-1930. [CrossRef]

38. Sung, K.-M.; Holm, R.H. Oxo Transfer Reactions Mediated by Bis(dithiolene)tungsten Analogues of the Active Sites of Molybdoenzymes in the DMSO Reductase Family: Comparative Reactivity of Tungsten and Molybdenum. J. Am. Chem. Soc. 2001, 123, 1931-1943. [CrossRef] [PubMed]

39. Seo, J.; Shearer, J.; Williard, P.G.; Kim, E. Reactivity of a biomimetic W(iv) bis-dithiolene complex with $\mathrm{CO}_{2}$ leading to formate production and structural rearrangement. Dalton Trans. 2019, 48, 17441-17444. [CrossRef] [PubMed]

40. Fogeron, T.; Todorova, T.K.; Porcher, J.-P.; Gomez-Mingot, M.; Chamoreau, L.-M.; Mellot-Draznieks, C.; Li, Y.; Fontecave, M. A Bioinspired Nickel(bis-dithiolene) Complex as a Homogeneous Catalyst for Carbon Dioxide Electroreduction. ACS Catal. 2018, 8 , 2030-2038. [CrossRef]

41. Fogeron, T.; Retailleau, P.; Chamoreau, L.-M.; Li, Y.; Fontecave, M. Pyranopterin Related Dithiolene Molybdenum Complexes as Homogeneous Catalysts for CO2 Photoreduction. Angew. Chem. Int. 2018, 57, 17033-17037. [CrossRef] [PubMed]

42. Mouchfiq, A.; Todorova, T.K.; Dey, S.; Fontecave, M.; Mougel, V. A bioinspired molybdenum-copper molecular catalyst for $\mathrm{CO}_{2}$ electroreduction. Chem. Sci. 2020, 11, 5503-5510. [CrossRef] [PubMed]

43. Chisholm, M.H.; Cotton, F.A.; Extine, M.W.; Reichert, W.W. The molybdenum-molybdenum triple bond Insertion reactions of hexakis(alkoxy)dimolybdenum compounds with carbon dioxide and single-crystal x-ray structural characterization of bis(tertbutylcarbonato)tetrakis(tert-butoxy)dimolybdenum. J. Am. Chem. Soc. 1978, 100, 1727-1734. [CrossRef] 
44. Alvarez, R.; Carmona, E.; Cole-Hamilton, D.J.; Galindo, A.; Gutierrez-Puebla, E.; Monge, A.; Poveda, M.L.; Ruiz, C. Formation of acrylic acid derivatives from the reaction of carbon dioxide with ethylene complexes of molybdenum and tungsten. J. Am. Chem. Soc. 1985, 107, 5529-5531. [CrossRef]

45. Chakraborty, S.; Blacque, O.; Berke, H. Ligand assisted carbon dioxide activation and hydrogenation using molybdenum and tungsten amides. Dalton Trans. 2015, 44, 6560-6570. [CrossRef]

46. Man, M.L.; Zhou, Z.; Ng, S.M.; Lau, C.P. Synthesis, characterization and reactivity of heterobimetallic complexes $\left(\eta^{5}-\mathrm{C}_{5} \mathrm{R}_{5}\right) \mathrm{Ru}(\mathrm{CO})(\mu$-dppm $) \mathrm{M}(\mathrm{CO})_{2}\left(\eta^{5}-\mathrm{C}_{5} \mathrm{H}_{5}\right)\left(\mathrm{R}=\mathrm{H}, \mathrm{CH}_{3} ; \mathrm{M}=\mathrm{Mo}, \mathrm{W}\right)$. Interconversion of hydrogen/carbon dioxide and formic acid by these complexes. Dalton Trans. 2003, 3727-3735. [CrossRef]

47. Minato, M.; Zhou, D.-Y.; Sumiura, K.-I.; Oshima, Y.; Mine, S.; Ito, T.; Kakeya, M.; Hoshino, K.; Asaeda, T.; Nakada, T.; et al. Reactivity Patterns of $\mathrm{O}_{2}, \mathrm{CO}_{2}$, Carboxylic Acids, and Triflic Acid with Molybdenum Silyl Hydrido Complexes Bearing Polydentate Phosphinoalkyl-Silyl Ligands: Pronounced Effects of Silyl Ligands on Reactions. Organometallics 2012, 31, 4941-4949. [CrossRef]

48. McWeeny, R.; Mason, R.; Towl, A.D.C. The geometries of and bonding in certain transition metal complexes. Discuss. Faraday Soc. 1969, 47, 20-26. [CrossRef]

49. Haszeldine, R.N.; Parish, R.V.; Setchfield, J.H. Organosilicon chemistry: XI. The stereochemistry of $\left.\operatorname{Ir}(\mathrm{H}) \mathrm{Cl}(\mathrm{SiR})_{3}\right) \mathrm{CO}\left(\mathrm{PPh}_{3}\right)_{2}$, and the trans-influence of substituted silyl, germyl, and stannyl groups. J. Organomet. Chem. 1973, 57, 279-285. [CrossRef]

50. Mukhopadhyay, T.K.; Flores, M.; Groy, T.L.; Trovitch, R.J. A Highly Active Manganese Precatalyst for the Hydrosilylation of Ketones and Esters. J. Am. Chem. Soc. 2014, 136, 882-885. [CrossRef]

51. Pal, R.; Groy, T.L.; Trovitch, R.J. Conversion of Carbon Dioxide to Methanol Using a C-H Activated Bis(imino)pyridine Molybdenum Hydroboration Catalyst. Inorg. Chem. 2015, 54, 7506-7515. [CrossRef] [PubMed]

52. Zhang, Y.; Hanna, B.S.; Dineen, A.; Williard, P.G.; Bernskoetter, W.H. Functionalization of Carbon Dioxide with Ethylene at Molybdenum Hydride Complexes. Organometallics 2013, 32, 3969-3979. [CrossRef]

53. Fong, L.K.; Fox, J.R.; Cooper, N.J. Reactions of carbon dioxide with the electron-rich polyhydride complex $\left[\mathrm{Mo}(\mathrm{dmpe})_{2} \mathrm{H}_{4}\right]$. Organometallics 1987, 6, 223-231. [CrossRef]

54. Hor, T.S.A.; Chee, S.-M. Substituted metal carbonyls: III. Chromium, molybdenum and tungsten tricarbonyl complexes containing bipyridyl and a unidentate diphosphine: Facile synthesis via trimethylamine $\mathrm{N}$-oxide-induced decarbonylations. J. Organomet. Chem. 1987, 331, 23-28. [CrossRef]

55. Clark, M.L.; Grice, K.A.; Moore, C.E.; Rheingold, A.L.; Kubiak, C.P. Electrocatalytic CO2 reduction by $\mathrm{M}(\mathrm{bpy}-\mathrm{R})(\mathrm{CO})_{4}(\mathrm{M}=\mathrm{Mo}$, $\mathrm{W}, \mathrm{R}=\mathrm{H}, \mathrm{tBu}$ ) complexes. Electrochemical, spectroscopic, and computational studies and comparison with group 7 catalysts. Chem. Sci. 2014, 5, 1894-1900. [CrossRef]

56. Zhang, Y.; MacIntosh, A.D.; Wong, J.L.; Bielinski, E.A.; Williard, P.G.; Mercado, B.Q.; Hazari, N.; Bernskoetter, W.H. Iron catalyzed $\mathrm{CO}_{2}$ hydrogenation to formate enhanced by Lewis acid co-catalysts. Chem. Sci. 2015, 6, 4291-4299. [CrossRef]

57. Zhang, Y.; Williard, P.G.; Bernskoetter, W.H. Synthesis and Characterization of Pincer-Molybdenum Precatalysts for $\mathrm{CO}_{2}$ Hydrogenation. Organometallics 2016, 35, 860-865. [CrossRef]

58. Summers, D.P.; Leach, S.; Frese, K.W. The electrochemical reduction of aqueous carbon dioxide to methanol at molybdenum electrodes with low overpotentials. J. Electroanal. Chem. 1986, 205, 219-232. [CrossRef]

59. Asadi, M.; Kumar, B.; Behranginia, A.; Rosen, B.A.; Baskin, A.; Repnin, N.; Pisasale, D.; Phillips, P.; Zhu, W.; Haasch, R.; et al. Robust carbon dioxide reduction on molybdenum disulphide edges. Nat. Commun. 2014, 5, 4470. [CrossRef] [PubMed]

60. Abbasi, P.; Asadi, M.; Liu, C.; Sharifi-Asl, S.; Sayahpour, B.; Behranginia, A.; Zapol, P.; Shahbazian-Yassar, R.; Curtiss, L.A.; Salehi-Khojin, A. Tailoring the Edge Structure of Molybdenum Disulfide toward Electrocatalytic Reduction of Carbon Dioxide. ACS Nano 2017, 11, 453-460. [CrossRef]

61. DiMeglio, J.L.; Rosenthal, J. Selective Conversion of CO2 to CO with High Efficiency Using an Inexpensive Bismuth-Based Electrocatalyst. J. Am. Chem. Soc. 2013, 135, 8798-8801. [CrossRef]

62. Sun, X.; Zhu, Q.; Kang, X.; Liu, H.; Qian, Q.; Zhang, Z.; Han, B. Molybdenum-Bismuth Bimetallic Chalcogenide Nanosheets for Highly Efficient Electrocatalytic Reduction of Carbon Dioxide to Methanol. Angew. Chem. Int. Ed. 2016, 55, 6771-6775. [CrossRef]

63. Gattrell, M.; Gupta, N.; Co, A. A review of the aqueous electrochemical reduction of $\mathrm{CO}_{2}$ to hydrocarbons at copper. J. Electroanal. Chem 2006, 594, 1-19. [CrossRef]

64. Shi, G.; Yu, L.; Ba, X.; Zhang, X.; Zhou, J.; Yu, Y. Copper nanoparticle interspersed $\mathrm{MoS}_{2}$ nanoflowers with enhanced efficiency for $\mathrm{CO}_{2}$ electrochemical reduction to fuel. Dalton Trans. 2017, 46, 10569-10577. [CrossRef] [PubMed]

65. Li, H.; Liu, X.; Chen, S.; Yang, D.; Zhang, Q.; Song, L.; Xiao, H.; Zhang, Q.; Gu, L.; Wang, X. Edge-Exposed Molybdenum Disulfide with N-Doped Carbon Hybridization: A Hierarchical Hollow Electrocatalyst for Carbon Dioxide Reduction. Adv. Energy Mater. 2019, 9, 1900072. [CrossRef]

66. Lv, K.; Suo, W.; Shao, M.; Zhu, Y.; Wang, X.; Feng, J.; Fang, M.; Zhu, Y. Nitrogen doped MoS $_{2}$ and nitrogen doped carbon dots composite catalyst for electroreduction $\mathrm{CO}_{2}$ to $\mathrm{CO}$ with high Faradaic efficiency. Nano Energy 2019, 63, 103834. [CrossRef]

67. Asadi, M.; Motevaselian, M.H.; Moradzadeh, A.; Majidi, L.; Esmaeilirad, M.; Sun, T.V.; Liu, C.; Bose, R.; Abbasi, P.; Zapol, P.; et al. Highly Efficient Solar-Driven Carbon Dioxide Reduction on Molybdenum Disulfide Catalyst Using Choline Chloride-Based Electrolyte. Adv. Energy Mater. 2019, 9, 1803536. [CrossRef] 
68. Xu, J.; Li, X.; Liu, W.; Sun, Y.; Ju, Z.; Yao, T.; Wang, C.; Ju, H.; Zhu, J.; Wei, S.; et al. Carbon Dioxide Electroreduction into Syngas Boosted by a Partially Delocalized Charge in Molybdenum Sulfide Selenide Alloy Monolayers. Angew. Chem. Int. Ed. 2017, 56, 9121-9125. [CrossRef] [PubMed]

69. Sun, X.; Lu, L.; Zhu, Q.; Wu, C.; Yang, D.; Chen, C.; Han, B. MoP Nanoparticles Supported on Indium-Doped Porous Carbon: Outstanding Catalysts for Highly Efficient $\mathrm{CO}_{2}$ Electroreduction. Angew. Chem. Int. Ed. 2018, 57, 2427-2431. [CrossRef] [PubMed]

70. Kumar, P.; Kumar, S.; Cordier, S.; Paofai, S.; Boukherroub, R.; Jain, S.L. Photoreduction of $\mathrm{CO}_{2}$ to methanol with hexanuclear molybdenum [ $\left.\mathrm{Mo}_{6} \mathrm{Br}_{14}\right]^{2-}$ cluster units under visible light irradiation. RSC Adv. 2014, 4, 10420-10423. [CrossRef]

71. Kumar, P.; Mungse, H.P.; Cordier, S.; Boukherroub, R.; Khatri, O.P.; Jain, S.L. Hexamolybdenum clusters supported on graphene oxide: Visible-light induced photocatalytic reduction of carbon dioxide into methanol. Carbon 2015, 94, 91-100. [CrossRef]

72. Jackson, J.A.; Turro, C.; Newsham, M.D.; Nocera, D.G. Oxygen quenching of electronically excited hexanuclear molybdenum and tungsten halide clusters. J. Phys. Chem. A 1990, 94, 4500-4507. [CrossRef]

73. Cordier, S.; Kirakci, K.; Méry, D.; Perrin, C.; Astruc, D. Mo6X8i Nanocluster cores (X=Br, I): From inorganic solid state compounds to hybrids. Inorganica Chim. Acta 2006, 359, 1705-1709. [CrossRef]

74. Srikanth, S.; Maesen, M.; Dominguez-Benetton, X.; Vanbroekhoven, K.; Pant, D. Enzymatic electrosynthesis of formate through $\mathrm{CO}_{2}$ sequestration/reduction in a bioelectrochemical system (BES). Bioresour. Technol. 2014, 165, 350-354. [CrossRef] [PubMed]

75. Kim, S.; Kim, M.K.; Lee, S.H.; Yoon, S.; Jung, K.-D. Conversion of $\mathrm{CO}_{2}$ to formate in an electroenzymatic cell using Candida boidinii formate dehydrogenase. J. Mol. Catal. B Enzym. 2014, 102, 9-15. [CrossRef]

76. Kim, S.-H.; Chung, G.-Y.; Kim, S.-H.; Vinothkumar, G.; Yoon, S.-H.; Jung, K.-D. Electrochemical NADH regeneration and electroenzymatic $\mathrm{CO}_{2}$ reduction on $\mathrm{Cu}$ nanorods/glassy carbon electrode prepared by cyclic deposition. Electrochim. Acta 2016, 210, 837-845. [CrossRef]

77. Amao, Y.; Shuto, N. Formate dehydrogenase-viologen-immobilized electrode for $\mathrm{CO}_{2}$ conversion, for development of an artificial photosynthesis system. Res. Chem. Intermed. 2014, 40, 3267-3276. [CrossRef]

78. Srikanth, S.; Alvarez-Gallego, Y.; Vanbroekhoven, K.; Pant, D. Enzymatic Electrosynthesis of Formic Acid through Carbon Dioxide Reduction in a Bioelectrochemical System: Effect of Immobilization and Carbonic Anhydrase Addition. ChemPhysChem 2017, 18, 3174-3181. [CrossRef]

79. Zhang, L.; Liu, J.; Ong, J.; Li, S.F.Y. Specific and sustainable bioelectro-reduction of carbon dioxide to formate on a novel enzymatic cathode. Chemosphere 2016, 162, 228-234. [CrossRef]

80. Bassegoda, A.; Madden, C.; Wakerley, D.W.; Reisner, E.; Hirst, J. Reversible Interconversion of $\mathrm{CO}_{2}$ and Formate by a MolybdenumContaining Formate Dehydrogenase. J. Am. Chem. Soc. 2014, 136, 15473-15476. [CrossRef]

81. Yuan, M.; Sahin, S.; Cai, R.; Abdellaoui, S.; Hickey, D.P.; Minteer, S.D.; Milton, R.D. Creating a Low-Potential Redox Polymer for Efficient Electroenzymatic $\mathrm{CO}_{2}$ Reduction. Angew. Chem. Int. Ed. 2018, 57, 6582-6586. [CrossRef]

82. Ferguson, S.J. Nitrogen cycle enzymology. Curr. Opin. Chem. Biol. 1998, 2, 182-193. [CrossRef]

83. Raymond, J.; Siefert, J.L.; Staples, C.R.; Blankenship, R.E. The Natural History of Nitrogen Fixation. Mol. Biol. Evol. 2004, 21, 541-554. [CrossRef] [PubMed]

84. Shilov, A.E. Catalytic reduction of molecular nitrogen in solutions. Russ. Chem. Bull. 2003, 52, 2555-2562. [CrossRef]

85. Haber, F.J.N. The production of ammonia from nitrogen and hydrogen. Naturwissenschaften 1922, 10, 1041. [CrossRef]

86. Service, R.F. New recipe produces ammonia from air, water, and sunlight. Science 2014. [CrossRef]

87. Eady, R.R. Structure-Function Relationships of Alternative Nitrogenases. Chem. Rev. 1996, 96, 3013-3030. [CrossRef]

88. Garagounis, I.; Kyriakou, V.; Skodra, A.; Vasileiou, E.; Stoukides, M. Electrochemical Synthesis of Ammonia in Solid Electrolyte Cells. Front. Energy Res. 2014, 2. [CrossRef]

89. Jia, H.-P.; Quadrelli, E.A. Mechanistic aspects of dinitrogen cleavage and hydrogenation to produce ammonia in catalysis and organometallic chemistry: Relevance of metal hydride bonds and dihydrogen. Chem. Soc. Rev. 2014, 43, 547-564. [CrossRef]

90. MacKay, B.A.; Fryzuk, M.D. Dinitrogen Coordination Chemistry: On the Biomimetic Borderlands. Chem. Rev. 2004, 104, 385-402. [CrossRef]

91. Deng, H.; Hoffmann, R. How N2 Might Be Activated by the FeMo-Cofactor in Nitrogenase. Angew. Chem. Int. Ed. 1993, 32, 1062-1065. [CrossRef]

92. Burgess, B.K.; Lowe, D.J. Mechanism of Molybdenum Nitrogenase. Chem. Rev. 1996, 96, 2983-3012. [CrossRef]

93. Howard, J.B.; Rees, D.C. Structural Basis of Biological Nitrogen Fixation. Chem. Rev. 1996, 96, 2965-2982. [CrossRef]

94. Hoffman, B.M.; Lukoyanov, D.; Yang, Z.-Y.; Dean, D.R.; Seefeldt, L.C. Mechanism of Nitrogen Fixation by Nitrogenase: The Next Stage. Chem. Rev. 2014, 114, 4041-4062. [CrossRef]

95. Spatzal, T.; Aksoyoglu, M.; Zhang, L.; Andrade, S.L.A.; Schleicher, E.; Weber, S.; Rees, D.C.; Einsle, O. Evidence for Interstitial Carbon in Nitrogenase FeMo Cofactor. Science 2011, 334, 940. [CrossRef]

96. Lancaster, K.M.; Roemelt, M.; Ettenhuber, P.; Hu, Y.; Ribbe, M.W.; Neese, F.; Bergmann, U.; DeBeer, S. X-ray Emission Spectroscopy Evidences a Central Carbon in the Nitrogenase Iron-Molybdenum Cofactor. Science 2011, 334, 974. [CrossRef] [PubMed]

97. Wiig, J.A.; Hu, Y.; Lee, C.C.; Ribbe, M.W. Radical SAM-Dependent Carbon Insertion into the Nitrogenase M-Cluster. Science 2012, 337, 1672. [CrossRef]

98. Wolff, T.E.; Berg, J.M.; Warrick, C.; Hodgson, K.O.; Holm, R.H.; Frankel, R.B. The molybdenum-iron-sulfur cluster complex $\left[\mathrm{Mo} 2 \mathrm{Fe} 6 \mathrm{~S} 9\left(\mathrm{SC}_{2} \mathrm{H}_{5}\right)_{8}\right]^{3-}$. A synthetic approach to the molybdenum site in nitrogenase. J. Am. Chem. Soc. 1978, 100, 4630-4632. [CrossRef] 
99. Wolff, T.E.; Berg, J.M.; Hodgson, K.O.; Frankel, R.B.; Holm, R.H. Synthetic approaches to the molybdenum site in nitrogenase. Preparation and structural properties of the molybdenum-iron-sulfur "double-cubane" cluster complexes $\left[\mathrm{Mo}_{2} \mathrm{Fe}_{6} \mathrm{~S}_{8}\left(\mathrm{SC}_{2} \mathrm{H}_{5}\right)_{9}\right]^{3-}$ and $\left[\mathrm{Mo}_{2} \mathrm{Fe}_{6} \mathrm{~S}_{9}\left(\mathrm{SC}_{2} \mathrm{H}_{5}\right)_{8}\right]_{3}$. J. Am. Chem. Soc. 1979, 101, 4140-4150. [CrossRef]

100. Armstrong, W.H.; Holm, R.H. Synthesis and structure of a new type of molybdenum-iron-sulfur double-cubane cluster and evidence for formation of magnetically uncoupled $\mathrm{S}=3 / 2 \mathrm{MoFe}_{3} \mathrm{~S}_{4}$ subclusters. J. Am. Chem. Soc. 1981, 103, 6246-6248. [CrossRef]

101. Armstrong, W.H.; Mascharak, P.K.; Holm, R.H. Doubly bridged double cubanes containing $\mathrm{MFe}_{3} \mathrm{~S}_{4}$ clusters $(\mathrm{M}=\mathrm{Mo}$, W). Synthesis, structure, and conversion to spin-quartet single clusters in solution. J. Am. Chem. Soc. 1982, 104, 4373-4383. [CrossRef]

102. Cramer, S.P.; Gillum, W.O.; Hodgson, K.O.; Mortenson, L.E.; Stiefel, E.I.; Chisnell, J.R.; Brill, W.J.; Shah, V.K. The molybdenum site of nitrogenase. 2. A comparative study of molybdenum-iron proteins and the iron-molybdenum cofactor by $\mathrm{x}$-ray absorption spectroscopy. J. Am. Chem. Soc. 1978, 100, 3814-3819. [CrossRef]

103. Coucouvanis, D.; Demadis, K.D.; Kim, C.G.; Dunham, R.W.; Kampf, J.W. Single and double $\mathrm{MoFe}_{3} \mathrm{~S}_{4}$ cubanes with molybdenumcoordinated polycarboxylate ligands. Syntheses and structural characterization of $\left(\mathrm{Et}_{4} \mathrm{~N}\right)_{4}\left\{\left[\mathrm{MoFe}_{3} \mathrm{~S}_{4} \mathrm{Cl}_{4}\right]_{2}\left(\mu-\mathrm{C}_{2} \mathrm{O}_{4}\right)\right\}$ and $\left(\mathrm{Et}_{4} \mathrm{~N}\right)_{3}\left(\left[\mathrm{MoFe}_{3} \mathrm{~S}_{4} \mathrm{Cl}_{4}\left(\mathrm{C}_{2} \mathrm{O}_{4}\right)\right]\right.$ clusters. J. Am. Chem. Soc. 1993, 115, 3344-3345. [CrossRef]

104. Fomitchev, D.V.; McLauchlan, C.C.; Holm, R.H. Heterometal Cubane-Type $\mathrm{MFe}_{3} \mathrm{~S}_{4}$ Clusters $(\mathrm{M}=\mathrm{Mo}$, V) Trigonally Symmetrized with Hydrotris(pyrazolyl)borate(1-) and Tris(pyrazolyl)methanesulfonate(1-) Capping Ligands. Inorg. Chem. 2002, 41, 958-966. [CrossRef]

105. Bjornsson, R.; Neese, F.; Schrock, R.R.; Einsle, O.; DeBeer, S. The discovery of Mo(III) in FeMoco: Reuniting enzyme and model chemistry. J. Biol. Inorg. Chem. 2015, 20, 447-460. [CrossRef]

106. Yang, J. Progress in Synthesizing Analogues of Nitrogenase Metalloclusters for Catalytic Reduction of Nitrogen to Ammonia. Catalysts 2019, 9, 939. [CrossRef]

107. Tanifuji, K.; Ohki, Y. Metal-Sulfur Compounds in $\mathrm{N}_{2}$ Reduction and Nitrogenase-Related Chemistry. Chem. Rev. 2020, 120, 5194-5251. [CrossRef]

108. Komori, K.; Oshita, H.; Mizobe, Y.; Hidai, M. Preparation and properties of molybdenum and tungsten dinitrogen complexes. J. Am. Chem. Soc. 1989, 111, 1939-1940. [CrossRef]

109. Yandulov, D.V.; Schrock, R.R. Catalytic Reduction of Dinitrogen to Ammonia at a Single Molybdenum Center. Science 2003, 301, 76. [CrossRef]

110. Yandulov, D.V.; Schrock, R.R. Reduction of Dinitrogen to Ammonia at a Well-Protected Reaction Site in a Molybdenum Triamidoamine Complex. J. Am. Chem. Soc. 2002, 124, 6252-6253. [CrossRef]

111. Foster, S.L.; Bakovic, S.I.P.; Duda, R.D.; Maheshwari, S.; Milton, R.D.; Minteer, S.D.; Janik, M.J.; Renner, J.N.; Greenlee, L.F. Catalysts for nitrogen reduction to ammonia. Nat. Catal. 2018, 1, 490-500. [CrossRef]

112. Schrock, R.R. Catalytic reduction of dinitrogen under mild conditions. Chem. Commun. 2003, 19, 2389-2391. [CrossRef]

113. Yandulov, D.V.; Schrock, R.R.; Rheingold, A.L.; Ceccarelli, C.; Davis, W.M. Synthesis and Reactions of Molybdenum Triamidoamine Complexes Containing Hexaisopropylterphenyl Substituents. Inorg. Chem. 2003, 42, 796-813. [CrossRef] [PubMed]

114. Ritleng, V.; Yandulov, D.V.; Weare, W.W.; Schrock, R.R.; Hock, A.S.; Davis, W.M. Molybdenum Triamidoamine Complexes that Contain Hexa-tert-butylterphenyl, Hexamethylterphenyl, or p-Bromohexaisopropylterphenyl Substituents. An Examination of Some Catalyst Variations for the Catalytic Reduction of Dinitrogen. J. Am. Chem. Soc. 2004, 126, 6150-6163. [CrossRef]

115. Schrock, R.R. Catalytic Reduction of Dinitrogen to Ammonia at a Single Molybdenum Center. Acc. Chem. Res. 2005, 38, 955-962. [CrossRef] [PubMed]

116. Yandulov, D.V.; Schrock, R.R. Studies Relevant to Catalytic Reduction of Dinitrogen to Ammonia by Molybdenum Triamidoamine Complexes. Inorg. Chem. 2005, 44, 1103-1117. [CrossRef]

117. Schrock, R.R. Reduction of dinitrogen. Proc. Natl. Acad. Sci. USA 2006, 103, 17087. [CrossRef]

118. Schrock, R.R. Catalytic Reduction of Dinitrogen to Ammonia by Molybdenum: Theory versus Experiment. Angew. Chem. Int. Ed. 2008, 47, 5512-5522. [CrossRef]

119. Tanaka, H.; Sasada, A.; Kouno, T.; Yuki, M.; Miyake, Y.; Nakanishi, H.; Nishibayashi, Y.; Yoshizawa, K. Molybdenum-Catalyzed Transformation of Molecular Dinitrogen into Silylamine: Experimental and DFT Study on the Remarkable Role of Ferrocenyldiphosphine Ligands. J. Am. Chem. Soc. 2011, 133, 3498-3506. [CrossRef]

120. Arashiba, K.; Miyake, Y.; Nishibayashi, Y. A molybdenum complex bearing PNP-type pincer ligands leads to the catalytic reduction of dinitrogen into ammonia. Nat. Chem. 2011, 3, 120-125. [CrossRef]

121. Nishibayashi, Y. Molybdenum-catalyzed reduction of molecular dinitrogen under mild reaction conditions. Dalton Trans. 2012, 41, 7447-7453. [CrossRef]

122. Kuriyama, S.; Arashiba, K.; Nakajima, K.; Tanaka, H.; Kamaru, N.; Yoshizawa, K.; Nishibayashi, Y. Catalytic Formation of Ammonia from Molecular Dinitrogen by Use of Dinitrogen-Bridged Dimolybdenum-Dinitrogen Complexes Bearing PNP-Pincer Ligands: Remarkable Effect of Substituent at PNP-Pincer Ligand. J. Am. Chem. Soc. 2014, 136, 9719-9731. [CrossRef]

123. Kuriyama, S.; Arashiba, K.; Nakajima, K.; Tanaka, H.; Yoshizawa, K.; Nishibayashi, Y. Nitrogen fixation catalyzed by ferrocenesubstituted dinitrogen-bridged dimolybdenum-dinitrogen complexes: Unique behavior of ferrocene moiety as redox active site. Chem. Sci. 2015, 6, 3940-3951. [CrossRef] 
124. Itabashi, T.; Mori, I.; Arashiba, K.; Eizawa, A.; Nakajima, K.; Nishibayashi, Y. Effect of substituents on molybdenum triiodide complexes bearing PNP-type pincer ligands toward catalytic nitrogen fixation. Dalton Trans. 2019, 48, 3182-3186. [CrossRef] [PubMed]

125. Arashiba, K.; Eizawa, A.; Tanaka, H.; Nakajima, K.; Yoshizawa, K.; Nishibayashi, Y. Catalytic Nitrogen Fixation via Direct Cleavage of Nitrogen-Nitrogen Triple Bond of Molecular Dinitrogen under Ambient Reaction Conditions. Bull. Chem. Soc. Jpn. 2017, 90, 1111-1118. [CrossRef]

126. Eizawa, A.; Arashiba, K.; Egi, A.; Tanaka, H.; Nakajima, K.; Yoshizawa, K.; Nishibayashi, Y. Catalytic Reactivity of MolybdenumTrihalide Complexes Bearing PCP-Type Pincer Ligands. Chem. Asian J. 2019, 14, 2091-2096. [CrossRef] [PubMed]

127. Ashida, Y.; Arashiba, K.; Nakajima, K.; Nishibayashi, Y. Molybdenum-catalysed ammonia production with samarium diiodide and alcohols or water. Nature 2019, 568, 536-540. [CrossRef]

128. Brown, K.A.; Harris, D.F.; Wilker, M.B.; Rasmussen, A.; Khadka, N.; Hamby, H.; Keable, S.; Dukovic, G.; Peters, J.W.; Seefeldt, L.C.J.S. Light-driven dinitrogen reduction catalyzed by a CdS: Nitrogenase MoFe protein biohybrid. Science 2016, 352, 448-450. [CrossRef]

129. Nazemi, M.; Panikkanvalappil, S.R.; El-Sayed, M.A. Enhancing the rate of electrochemical nitrogen reduction reaction for ammonia synthesis under ambient conditions using hollow gold nanocages. Nano Energy 2018, 49, 316-323. [CrossRef]

130. Manjunatha, R.; Schechter, A. Electrochemical synthesis of ammonia using ruthenium-platinum alloy at ambient pressure and low temperature. Electrochem. Commun. 2018, 90, 96-100. [CrossRef]

131. Tao, H.; Choi, C.; Ding, L.-X.; Jiang, Z.; Han, Z.; Jia, M.; Fan, Q.; Gao, Y.; Wang, H.; Robertson, A.W.; et al. Nitrogen Fixation by Ru Single-Atom Electrocatalytic Reduction. Chem 2019, 5, 204-214. [CrossRef]

132. Liu, H.-M.; Han, S.-H.; Zhao, Y.; Zhu, Y.-Y.; Tian, X.-L.; Zeng, J.-H.; Jiang, J.-X.; Xia, B.Y.; Chen, Y. Surfactant-free atomically ultrathin rhodium nanosheet nanoassemblies for efficient nitrogen electroreduction. J. Mater. Chem. A 2018, 6, $3211-3217$. [CrossRef]

133. Huang, H.; Xia, L.; Shi, X.; Asiri, A.M.; Sun, X. Ag nanosheets for efficient electrocatalytic $\mathrm{N}_{2}$ fixation to NH3 under ambient conditions. Chem. Commun. 2018, 54, 11427-11430. [CrossRef]

134. Oshikiri, T.; Ueno, K.; Misawa, H. Selective Dinitrogen Conversion to Ammonia Using Water and Visible Light through Plasmon-induced Charge Separation. Angew. Chem. Int. Ed. 2016, 55, 3942-3946. [CrossRef]

135. Wang, H.; Li, Y.; Li, C.; Deng, K.; Wang, Z.; Xu, Y.; Li, X.; Xue, H.; Wang, L. One-pot synthesis of bi-metallic PdRu tripods as an efficient catalyst for electrocatalytic nitrogen reduction to ammonia. J. Mater. Chem. A 2019, 7, 801-805. [CrossRef]

136. Montoya, J.H.; Tsai, C.; Vojvodic, A.; Nørskov, J.K. The Challenge of Electrochemical Ammonia Synthesis: A New Perspective on the Role of Nitrogen Scaling Relations. ChemSusChem 2015, 8, 2180-2186. [CrossRef]

137. Skúlason, E.; Bligaard, T.; Gudmundsdóttir, S.; Studt, F.; Rossmeisl, J.; Abild-Pedersen, F.; Vegge, T.; Jónsson, H.; Nørskov, J.K. A theoretical evaluation of possible transition metal electro-catalysts for $\mathrm{N}_{2}$ reduction. Phys. Chem. Chem. Phys. 2012, 14, 1235-1245. [CrossRef] [PubMed]

138. Yang, D.; Chen, T.; Wang, Z. Electrochemical reduction of aqueous nitrogen $\left(\mathrm{N}_{2}\right)$ at a low overpotential on (110)-oriented Mo nanofilm. J. Mater. Chem. A 2017, 5, 18967-18971. [CrossRef]

139. Zhu, D.; Zhang, L.; Ruther, R.E.; Hamers, R.J. Photo-illuminated diamond as a solid-state source of solvated electrons in water for nitrogen reduction. Nat. Mater. 2013, 12, 836-841. [CrossRef]

140. Kordali, V.; Kyriacou, G.; Lambrou, C. Electrochemical synthesis of ammonia at atmospheric pressure and low temperature in a solid polymer electrolyte cell. Chem. Commun. 2000, 1673-1674. [CrossRef]

141. Chen, S.; Perathoner, S.; Ampelli, C.; Mebrahtu, C.; Su, D.; Centi, G. Electrocatalytic Synthesis of Ammonia at Room Temperature and Atmospheric Pressure from Water and Nitrogen on a Carbon-Nanotube-Based Electrocatalyst. Angew. Chem. Int. Ed. 2017, 56, 2699-2703. [CrossRef] [PubMed]

142. Han, J.; Ji, X.; Ren, X.; Cui, G.; Li, L.; Xie, F.; Wang, H.; Li, B.; Sun, X. $\mathrm{MoO}_{3}$ nanosheets for efficient electrocatalytic $\mathrm{N}_{2}$ fixation to $\mathrm{NH}_{3}$. J. Mater. Chem. A 2018, 6, 12974-12977. [CrossRef]

143. Zhang, L.; Ji, X.; Ren, X.; Luo, Y.; Shi, X.; Asiri, A.M.; Zheng, B.; Sun, X. Efficient Electrochemical $\mathrm{N}_{2}$ Reduction to $\mathrm{NH}_{3}$ on $\mathrm{MoN}$ Nanosheets Array under Ambient Conditions. ACS Sustain. Chem. Eng. 2018, 6, 9550-9554. [CrossRef]

144. Zhang, L.; Ji, X.; Ren, X.; Ma, Y.; Shi, X.; Tian, Z.; Asiri, A.M.; Chen, L.; Tang, B.; Sun, X. Electrochemical Ammonia Synthesis via Nitrogen Reduction Reaction on a $\mathrm{MoS}_{2}$ Catalyst: Theoretical and Experimental Studies. Adv. Mat. 2018, 30, 1800191. [CrossRef] [PubMed]

145. Xu, X.; Sun, B.; Liang, Z.; Cui, H.; Tian, J. High-Performance Electrocatalytic Conversion of $\mathrm{N}_{2}$ to $\mathrm{NH}_{3} \mathrm{Using}_{1 \mathrm{~T}-\mathrm{MoS}} \mathrm{Annchored}$ on $\mathrm{Ti}_{3} \mathrm{C}_{2} \mathrm{MXene}$ under Ambient Conditions. ACS Appl. Mater. Interfaces 2020, 12, 26060-26067. [CrossRef] [PubMed]

146. Danyal, K.; Inglet, B.S.; Vincent, K.A.; Barney, B.M.; Hoffman, B.M.; Armstrong, F.A.; Dean, D.R.; Seefeldt, L.C. Uncoupling Nitrogenase: Catalytic Reduction of Hydrazine to Ammonia by a MoFe Protein in the Absence of Fe Protein-ATP. J. Am. Chem. Soc. 2010, 132, 13197-13199. [CrossRef]

147. Milton, R.D.; Abdellaoui, S.; Khadka, N.; Dean, D.R.; Leech, D.; Seefeldt, L.C.; Minteer, S.D. Nitrogenase bioelectrocatalysis: Heterogeneous ammonia and hydrogen production by MoFe protein. Energy Environ. Sci. 2016, 9, 2550-2554. [CrossRef]

148. Lee, Y.S.; Yuan, M.; Cai, R.; Lim, K.; Minteer, S.D. Nitrogenase Bioelectrocatalysis: ATP-Independent Ammonia Production Using a Redox Polymer/MoFe Protein System. ACS Catal. 2020, 10, 6854-6861. [CrossRef] 
149. Badalyan, A.; Yang, Z.-Y.; Seefeldt, L.C. A Voltammetric Study of Nitrogenase Catalysis Using Electron Transfer Mediators. ACS Catal. 2019, 9, 1366-1372. [CrossRef]

150. Jensen, B.B.; Burris, R.H. Nitrous oxide as a substrate and as a competitive inhibitor of nitrogenase. Biochemistry 1986, 25, 1083-1088. [CrossRef]

151. Davis, L.C. Hydrazine as a substrate and inhibitor of Azotobacter vinelandii nitrogenase. Arch. Biochem. Biophys. 1980, 204, 270-276. [CrossRef]

152. Vaughn, S.A.; Burgess, B.K. Nitrite, a new substrate for nitrogenase. Biochemistry 1989, 28, 419-424. [CrossRef] [PubMed]

153. Hosseini, S.E.; Wahid, M.A. Hydrogen production from renewable and sustainable energy resources: Promising green energy carrier for clean development. Renew. Sustain. Energy Rev. 2016, 57, 850-866. [CrossRef]

154. Vesborg, P.C.K.; Seger, B.; Chorkendorff, I. Recent Development in Hydrogen Evolution Reaction Catalysts and Their Practical Implementation. J. Phys. Chem. Lett. 2015, 6, 951-957. [CrossRef]

155. Shi, Y.; Zhang, B. Recent advances in transition metal phosphide nanomaterials: Synthesis and applications in hydrogen evolution reaction. Chem. Soc. Rev. 2016, 45, 1529-1541. [CrossRef]

156. Kong, D.; Cha, J.J.; Wang, H.; Lee, H.R.; Cui, Y. First-row transition metal dichalcogenide catalysts for hydrogen evolution reaction. Energy Environ. Sci. 2013, 6, 3553-3558. [CrossRef]

157. Darensbourg, D.J.; Reibenspies, J.H.; Lai, C.-H.; Lee, W.-Z.; Darensbourg, M.Y. Analysis of an Organometallic Iron Site Model for the Heterodimetallic Unit of [NiFe]Hydrogenase. J. Am. Chem. Soc. 1997, 119, 7903-7904. [CrossRef]

158. Donovan, E.S.; Felton, G.A.N. Electrochemical analysis of cyclopentadienylmetal carbonyl dimer complexes: Insight into the design of hydrogen-producing electrocatalysts. J. Organomet. Chem. 2012, 711, 25-34. [CrossRef]

159. Hu, C.; Fan, W.Y. Molybdenum carbonyl complexes as HER electrocatalysts. Mol. Catal. 2019, 479, 110615. [CrossRef]

160. DuBois, M.R.; VanDerveer, M.C.; DuBois, D.L.; Haltiwanger, R.C.; Miller, W.K. Characterization of reactions of hydrogen with coordinated sulfido ligands. J. Am. Chem. Soc. 1980, 102, 7456-7461. [CrossRef]

161. Appel, A.M.; DuBois, D.L.; Rakowski DuBois, M. Molybdenum-Sulfur Dimers as Electrocatalysts for the Production of Hydrogen at Low Overpotentials. J. Am. Chem. Soc. 2005, 127, 12717-12726. [CrossRef]

162. Karunadasa, H.I.; Montalvo, E.; Sun, Y.; Majda, M.; Long, J.R.; Chang, C.J. A Molecular MoS 2 Edge Site Mimic for Catalytic Hydrogen Generation. Science 2012, 335, 698. [CrossRef] [PubMed]

163. Karunadasa, H.I.; Chang, C.J.; Long, J.R. A molecular molybdenum-oxo catalyst for generating hydrogen from water. Nature 2010, 464, 1329-1333. [CrossRef] [PubMed]

164. Dave, M.; Rajagopal, A.; Damm-Ruttensperger, M.; Schwarz, B.; Nägele, F.; Daccache, L.; Fantauzzi, D.; Jacob, T.; Streb, C. Understanding homogeneous hydrogen evolution reactivity and deactivation pathways of molecular molybdenum sulfide catalysts. Sustain. Energ. Fuels 2018, 2, 1020-1026. [CrossRef]

165. Cao, J.-P.; Zhou, L.-L.; Fu, L.-Z.; Zhao, J.-X.; Lu, H.-X.; Zhan, S.-Z. A molybdenum-Schiff base complex, a new molecular electro-catalyst for generating hydrogen from acetic acid or water. Catal. Commun. 2014, 57, 1-4. [CrossRef]

166. Cao, J.-P.; Zhou, L.-L.; Fu, L.-Z.; Zhan, S. A molecular molybdenum electrocatalyst for generating hydrogen from acetic acid or water. J. Power Sources 2014, 272, 169-175. [CrossRef]

167. Seo, J.; Williard, P.G.; Kim, E. Deoxygenation of Mono-oxo Bis(dithiolene) Mo and W Complexes by Protonation. Inorg. Chem. 2013, 52, 8706-8712. [CrossRef]

168. Porcher, J.-P.; Fogeron, T.; Gomez-Mingot, M.; Derat, E.; Chamoreau, L.-M.; Li, Y.; Fontecave, M. A Bioinspired Molybdenum Complex as a Catalyst for the Photo- and Electroreduction of Protons. Angew. Chem. Int. Ed. 2015, 54, 14090-14093. [CrossRef]

169. Hinnemann, B.; Moses, P.G.; Bonde, J.; Jørgensen, K.P.; Nielsen, J.H.; Horch, S.; Chorkendorff, I.; Nørskov, J.K. Biomimetic Hydrogen Evolution: MoS2 Nanoparticles as Catalyst for Hydrogen Evolution. J. Am. Chem. Soc. 2005, 127, 5308-5309. [CrossRef]

170. Jaramillo, T.F.; Jørgensen, K.P.; Bonde, J.; Nielsen, J.H.; Horch, S.; Chorkendorff, I. Identification of Active Edge Sites for Electrochemical $\mathrm{H}_{2}$ Evolution from $\mathrm{MoS}_{2}$ Nanocatalysts. Science 2007, 317, 100. [CrossRef]

171. Seger, B.; Laursen, A.B.; Vesborg, P.C.K.; Pedersen, T.; Hansen, O.; Dahl, S.; Chorkendorff, I. Hydrogen Production Using a Molybdenum Sulfide Catalyst on a Titanium-Protected ${ }^{+} \mathrm{p}^{-}$Silicon Photocathode. Angew. Chem. Int. Ed. 2012, 51, 9128-9131. [CrossRef]

172. Merki, D.; Fierro, S.; Vrubel, H.; Hu, X. Amorphous molybdenum sulfide films as catalysts for electrochemical hydrogen production in water. Chem. Sci. 2011, 2, 1262-1267. [CrossRef]

173. Vrubel, H.; Merki, D.; Hu, X. Hydrogen evolution catalyzed by $\mathrm{MoS}_{3}$ and $\mathrm{MoS}_{2}$ particles. Energy Environ. Sci. 2012, 5, 6136-6144. [CrossRef]

174. Vrubel, H.; Hu, X. Growth and Activation of an Amorphous Molybdenum Sulfide Hydrogen Evolving Catalyst. ACS Catal. 2013, 3, 2002-2011. [CrossRef]

175. Jaramillo, T.F.; Bonde, J.; Zhang, J.; Ooi, B.-L.; Andersson, K.; Ulstrup, J.; Chorkendorff, I. Hydrogen Evolution on Supported Incomplete Cubane-type $\left[\mathrm{Mo}_{3} \mathrm{~S}_{4}\right]^{4+}$ Electrocatalysts. J. Phys. Chem. C 2008, 112, 17492-17498. [CrossRef]

176. Kibsgaard, J.; Jaramillo, T.F.; Besenbacher, F. Building an appropriate active-site motif into a hydrogen-evolution catalyst with thiomolybdate $\left[\mathrm{Mo}_{3} \mathrm{~S}_{13}\right]^{2-}$ clusters. Nat. Chem. 2014, 6, 248-253. [CrossRef]

177. Du, K.; Zheng, L.; Wang, T.; Zhuo, J.; Zhu, Z.; Shao, Y.; Li, M. Electrodeposited $\mathrm{Mo}_{3} \mathrm{~S}_{13}$ Films from $\left(\mathrm{NH}_{4}\right)_{2} \mathrm{Mo}_{3} \mathrm{~S}_{13} \cdot 2 \mathrm{H}_{2} \mathrm{O}$ for Electrocatalysis of Hydrogen Evolution Reaction. ACS Appl. Mater. Interfaces 2017, 9, 18675-18681. [CrossRef] [PubMed] 
178. Shang, Y.; Xu, X.; Gao, B.; Ren, Z. Thiomolybdate $\left[\mathrm{Mo}_{3} \mathrm{~S}_{13}\right]^{2-}$ Nanoclusters Anchored on Reduced Graphene Oxide-Carbon Nanotube Aerogels for Efficient Electrocatalytic Hydrogen Evolution. ACS Sustain. Chem. Eng. 2017, 5, 8908-8917. [CrossRef]

179. Huang, Z.; Luo, W.; Ma, L.; Yu, M.; Ren, X.; He, M.; Polen, S.; Click, K.; Garrett, B.; Lu, J.; et al. Dimeric $\left[\mathrm{Mo}_{2} \mathrm{~S}_{12}\right]^{2-} \mathrm{Cluster:}^{2}$ A Molecular Analogue of $\mathrm{MoS}_{2}$ Edges for Superior Hydrogen-Evolution Electrocatalysis. Angew. Chem. Int. Ed. 2015, 54, 15181-15185. [CrossRef]

180. Lei, Y.; Yang, M.; Hou, J.; Wang, F.; Cui, E.; Kong, C.; Min, S. Thiomolybdate $\left[\mathrm{Mo}_{3} \mathrm{~S}_{13}\right]^{2-}$ nanocluster: A molecular mimic of MoS 2 active sites for highly efficient photocatalytic hydrogen evolution. Chem. Commun. 2018, 54, 603-606. [CrossRef]

181. Cheng, Y.-J.; Wang, R.; Wang, S.; Xi, X.-J.; Ma, L.-F.; Zang, S.-Q. Encapsulating $\left[\mathrm{Mo}_{3} \mathrm{~S}_{13}\right]^{2-}$ clusters in cationic covalent organic frameworks: Enhancing stability and recyclability by converting a homogeneous photocatalyst to a heterogeneous photocatalyst. Chem. Commun. 2018, 54, 13563-13566. [CrossRef] [PubMed]

182. Tran, P.D.; Tran, T.V.; Orio, M.; Torelli, S.; Truong, Q.D.; Nayuki, K.; Sasaki, Y.; Chiam, S.Y.; Yi, R.; Honma, I.; et al. Coordination polymer structure and revisited hydrogen evolution catalytic mechanism for amorphous molybdenum sulfide. Nat. Mat. 2016, 15, 640-646. [CrossRef] [PubMed]

183. Feliz, M.; Puche, M.; Atienzar, P.; Concepción, P.; Cordier, S.; Molard, Y. In Situ Generation of Active Molybdenum Octahedral Clusters for Photocatalytic Hydrogen Production from Water. ChemSusChem 2016, 9, 1963-1971. [CrossRef] [PubMed]

184. Puche, M.; García-Aboal, R.; Mikhaylov, M.A.; Sokolov, M.N.; Atienzar, P.; Feliz, M.J.N. Enhanced Photocatalytic Activity and Stability in Hydrogen Evolution of $\mathrm{Mo}_{6}$ Iodide Clusters Supported on Graphene Oxide. Nanomaterials 2020, 10, 1259. [CrossRef]

185. Feliz, M.; Atienzar, P.; Amela-Cortés, M.; Dumait, N.; Lemoine, P.; Molard, Y.; Cordier, S. Supramolecular Anchoring of Octahedral Molybdenum Clusters onto Graphene and Their Synergies in Photocatalytic Water Reduction. Inorg. Chem. 2019, 58, 15443-15454. [CrossRef]

186. Recatalá, D.; Llusar, R.; Gushchin, A.L.; Kozlova, E.A.; Laricheva, Y.A.; Abramov, P.A.; Sokolov, M.N.; Gómez, R.; Lana-Villarreal, T. Photogeneration of Hydrogen from Water by Hybrid Molybdenum Sulfide Clusters Immobilized on Titania. ChemSusChem 2015, 8, 148-157. [CrossRef]

187. Tran, P.D.; Nguyen, M.; Pramana, S.S.; Bhattacharjee, A.; Chiam, S.Y.; Fize, J.; Field, M.J.; Artero, V.; Wong, L.H.; Loo, J.; et al. Copper molybdenum sulfide: A new efficient electrocatalyst for hydrogen production from water. Energy Environ. Sci. 2012, 5, 8912-8916. [CrossRef]

188. Gao, M.-R.; Liang, J.-X.; Zheng, Y.-R.; Xu, Y.-F.; Jiang, J.; Gao, Q.; Li, J.; Yu, S.-H. An efficient molybdenum disulfide/cobalt diselenide hybrid catalyst for electrochemical hydrogen generation. Nat. Commun. 2015, 6, 5982. [CrossRef]

189. Tang, H.; Dou, K.; Kaun, C.-C.; Kuang, Q.; Yang, S. MoSe 2 nanosheets and their graphene hybrids: Synthesis, characterization and hydrogen evolution reaction studies. J. Mater. Chem. A 2014, 2, 360-364. [CrossRef]

190. Chen, W.-F.; Sasaki, K.; Ma, C.; Frenkel, A.I.; Marinkovic, N.; Muckerman, J.T.; Zhu, Y.; Adzic, R.R. Hydrogen-Evolution Catalysts Based on Non-Noble Metal Nickel-Molybdenum Nitride Nanosheets. Angew. Chem. Int. Ed. 2012, 51, 6131-6135. [CrossRef]

191. Kibsgaard, J.; Jaramillo, T.F. Molybdenum Phosphosulfide: An Active, Acid-Stable, Earth-Abundant Catalyst for the Hydrogen Evolution Reaction. Angew. Chem. Int. Ed. 2014, 53, 14433-14437. [CrossRef]

192. Vrubel, H.; Hu, X. Molybdenum Boride and Carbide Catalyze Hydrogen Evolution in both Acidic and Basic Solutions. Angew. Chem. Int. Ed. 2012, 51, 12703-12706. [CrossRef] [PubMed]

193. Wan, C.; Regmi, Y.N.; Leonard, B.M. Multiple Phases of Molybdenum Carbide as Electrocatalysts for the Hydrogen Evolution Reaction. Angew. Chem. Int. Ed. 2014, 53, 6407-6410. [CrossRef] [PubMed]

194. Zhao, Y.; Kamiya, K.; Hashimoto, K.; Nakanishi, S. In Situ $\mathrm{CO}_{2}$-Emission Assisted Synthesis of Molybdenum Carbonitride Nanomaterial as Hydrogen Evolution Electrocatalyst. J. Am. Chem. Soc. 2015, 137, 110-113. [CrossRef] [PubMed]

195. Tang, Y.-J.; Gao, M.-R.; Liu, C.-H.; Li, S.-L.; Jiang, H.-L.; Lan, Y.-Q.; Han, M.; Yu, S.-H. Porous Molybdenum-Based Hybrid Catalysts for Highly Efficient Hydrogen Evolution. Angew. Chem. Int. Ed. 2015, 54, 12928-12932. [CrossRef] [PubMed]

196. Wang, C.; Lv, X.; Zhou, P.; Liang, X.; Wang, Z.; Liu, Y.; Wang, P.; Zheng, Z.; Dai, Y.; Li, Y.; et al. Molybdenum Nitride Electrocatalysts for Hydrogen Evolution More Efficient than Platinum/Carbon: $\mathrm{Mo}_{2} \mathrm{~N} / \mathrm{CeO}_{2} @ N i c k e l$ Foam. ACS Appl. Mater. Interfaces 2020, 12, 29153-29161. [CrossRef]

197. Mohanty, B.; Ghorbani-Asl, M.; Kretschmer, S.; Ghosh, A.; Guha, P.; Panda, S.K.; Jena, B.; Krasheninnikov, A.V.; Jena, B.K. MoS 2 Quantum Dots as Efficient Catalyst Materials for the Oxygen Evolution Reaction. ACS Catal. 2018, 8, 1683-1689. [CrossRef]

198. Hartley, C.L.; DiRisio, R.J.; Screen, M.E.; Mayer, K.J.; McNamara, W.R. Iron Polypyridyl Complexes for Photocatalytic Hydrogen Generation. Inorg. Chem. 2016, 55, 8865-8870. [CrossRef]

199. Jin, Y.; Wang, H.; Li, J.; Yue, X.; Han, Y.; Shen, P.K.; Cui, Y. Porous $\mathrm{MoO}_{2}$ Nanosheets as Non-noble Bifunctional Electrocatalysts for Overall Water Splitting. Adv. Mat. 2016, 28, 3785-3790. [CrossRef]

200. Gupta, S.; Patel, N.; Fernandes, R.; Hanchate, S.; Miotello, A.; Kothari, D.C. Co-Mo-B Nanoparticles as a non-precious and efficient Bifunctional Electrocatalyst for Hydrogen and Oxygen Evolution. Electrochim. Acta 2017, 232, 64-71. [CrossRef]

201. Zhao, S.; Huang, J.; Liu, Y.; Shen, J.; Wang, H.; Yang, X.; Zhu, Y.; Li, C. Multimetallic Ni-Mo/Cu nanowires as nonprecious and efficient full water splitting catalyst. J. Mater. Chem. A 2017, 5, 4207-4214. [CrossRef]

202. Liu, P.F.; Yang, S.; Zheng, L.R.; Zhang, B.; Yang, H.G. Mo ${ }^{6+}$ activated multimetal oxygen-evolving catalysts. Chemi. Sci. 2017, 8, 3484-3488. [CrossRef]

203. Yang, Y.; Zhang, K.; Lin, H.; Li, X.; Chan, H.C.; Yang, L.; Gao, Q. $\mathrm{MoS}_{2}-\mathrm{Ni}_{3} \mathrm{~S}_{2}$ Heteronanorods as Efficient and Stable Bifunctional Electrocatalysts for Overall Water Splitting. ACS Catal. 2017, 7, 2357-2366. [CrossRef] 
204. Tang, Y.-J.; Liu, C.-H.; Huang, W.; Wang, X.-L.; Dong, L.-Z.; Li, S.-L.; Lan, Y.-Q. Bimetallic Carbides-Based Nanocomposite as Superior Electrocatalyst for Oxygen Evolution Reaction. ACS Appl. Mater. Interfaces 2017, 9, 16977-16985. [CrossRef]

205. Jin, Y.; Huang, S.; Yue, X.; Du, H.; Shen, P.K. Mo- and Fe-Modified Ni(OH $)_{2} / \mathrm{NiOOH}$ Nanosheets as Highly Active and Stable Electrocatalysts for Oxygen Evolution Reaction. ACS Catal. 2018, 8, 2359-2363. [CrossRef]

206. Li, Y.; Xu, H.; Huang, H.; Wang, C.; Gao, L.; Ma, T. One-dimensional $\mathrm{MoO}_{2}-\mathrm{Co}_{2} \mathrm{Mo}_{3} \mathrm{O}_{8} @ \mathrm{C}$ nanorods: A novel and highly efficient oxygen evolution reaction catalyst derived from metal-organic framework composites. Chem. Commun. 2018, 54, 2739-2742. [CrossRef] [PubMed]

207. Yuan, Y.; Adimi, S.; Guo, X.; Thomas, T.; Zhu, Y.; Guo, H.; Priyanga, G.S.; Yoo, P.; Wang, J.; Chen, J.; et al. A Surface-Oxide-Rich Activation Layer (SOAL) on $\mathrm{Ni}_{2} \mathrm{Mo}_{3} \mathrm{~N}$ for a Rapid and Durable Oxygen Evolution Reaction. Angew. Chem. Int. Ed. 2020, 59, 18036-18041. [CrossRef]

208. Shi, H.; Zhou, Y.-T.; Yao, R.-Q.; Wan, W.-B.; Ge, X.; Zhang, W.; Wen, Z.; Lang, X.-Y.; Zheng, W.-T.; Jiang, Q. Spontaneously separated intermetallic $\mathrm{Co}_{3} \mathrm{Mo}$ from nanoporous copper as versatile electrocatalysts for highly efficient water splitting. Nat. Commun. 2020, 11, 2940. [CrossRef] 